\title{
Oxygen Handling and Cooling Options in High Temperature Electrolysis Plants
}

Manohar S. Sohal

J. Stephen Herring

July 2008

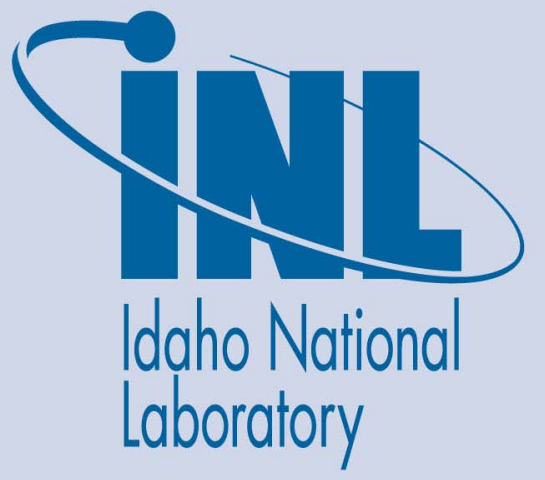

The INL is a U.S. Department of Energy National Laboratory operated by Battelle Energy Alliance 


\section{Oxygen Handling and Cooling Options in High Temperature Electrolysis Plants}

Manohar S. Sohal

J. Stephen Herring

July 2008

Idaho National Laboratory

Idaho Falls, Idaho 83415

Prepared for the

U.S. Department of Energy

Office of Nuclear Energy

Under DOE Idaho Operations Office

Contract DE-AC07-05ID14517 


\section{DISCLAIMER}

This information was prepared as an account of work sponsored by an agency of the U.S. Government. Neither the U.S. Government nor any agency thereof, nor any of their employees, makes any warranty, expressed or implied, or assumes any legal liability or responsibility for the accuracy, completeness, or usefulness, of any information, apparatus, product, or process disclosed, or represents that its use would not infringe privately owned rights. References herein to any specific commercial product, process, or service by trade name, trade mark, manufacturer, or otherwise, does not necessarily constitute or imply its endorsement, recommendation, or favoring by the U.S. Government or any agency thereof. The views and opinions of authors expressed herein do not necessarily state or reflect those of the U.S. Government or any agency thereof. 



\begin{abstract}
Idaho National Laboratory (INL) is working on a project to generate hydrogen by high temperature electrolysis (HTE). In such an HTE system, safety precautions need to be taken to handle high temperature oxygen at $\sim 830^{\circ} \mathrm{C}$. This report is aimed at addressing oxygen handling in a HTE plant. Though oxygen itself is not flammable, most engineering materials, including many gases and liquids, will burn in the presence of oxygen under some favorable physicochemical conditions. At present, an absolute set of rules does not exist that can cover all aspects of oxygen system design, material selection, and operating practices to avoid subtle hazards related to oxygen. Because most materials, including metals, will burn in an oxygen-enriched environment, hazards are always present when using oxygen. Most materials will ignite in an oxygen-enriched environment at a temperature lower than that in air, and once ignited, combustion rates are greater in the oxygen-enriched environment. However, these hazards do not preclude the operations and systems involving oxygen. Oxygen can be safely handled and used if all the materials in a system are not flammable in the end-use environment, or if ignition sources are identified and controlled. In fact, the incidence of oxygen system fires is reported to be low with a probability of about one in one million.

This report is a practical guide and tutorial for the safe operation and handling of gaseous oxygen in a high temperature electrolysis system. The intent is to provide safe, practical guidance that permits the accomplishment of experimental operations at INL, while being restrictive enough to prevent personnel endangerment and to provide reasonable facility protection. Adequate guidelines are provided to govern various aspects of oxygen handling associated with high temperature electrolysis system to generate hydrogen. The intent here is to present acceptable oxygen standards and practices for minimum safety requirements. A summary of operational hazards, along with oxygen safety and emergency procedures, are provided.
\end{abstract}




\section{CONTENTS}

ABSTRACT

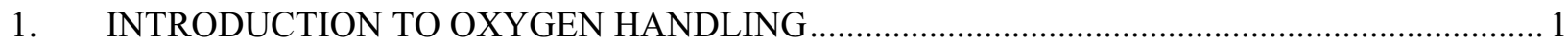

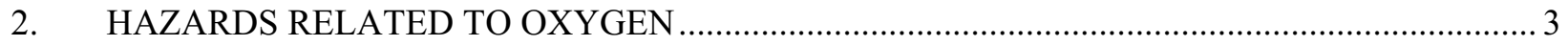

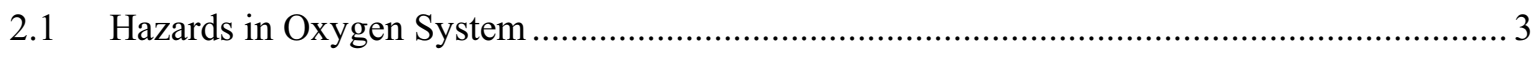

2.2 Parameters and Conditions Responsible for Hazards in Oxygen Handling ........................... 3

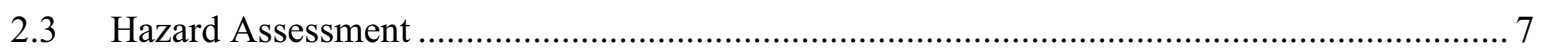

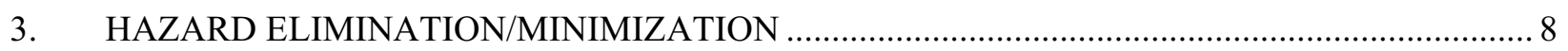

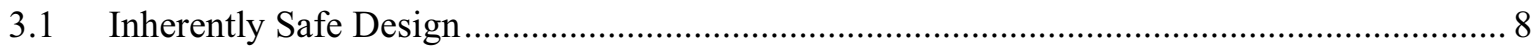

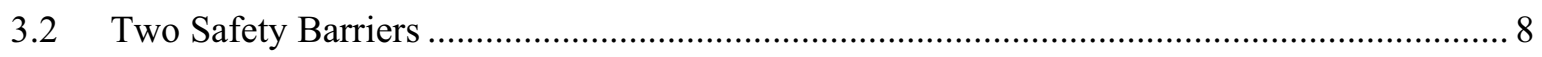

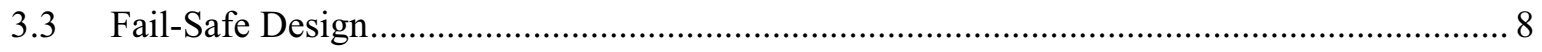

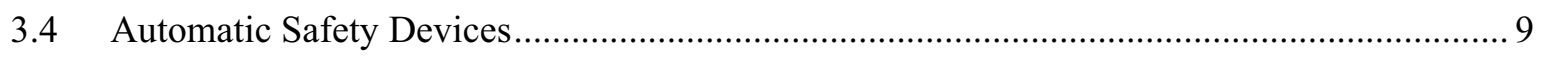

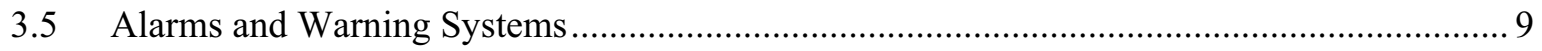

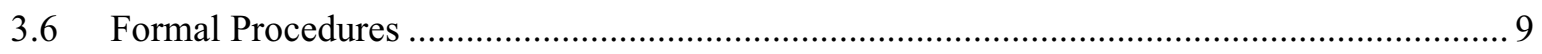

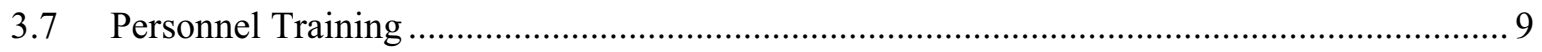

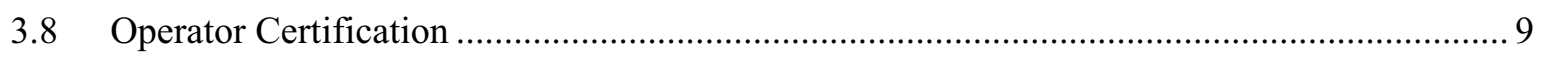

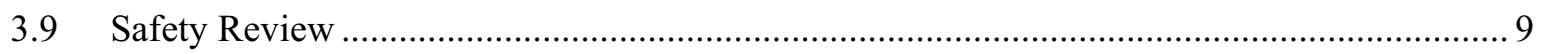

3.10 Reducing the Probability of the Oxygen Hazard ............................................................ 9

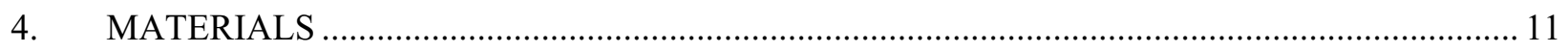

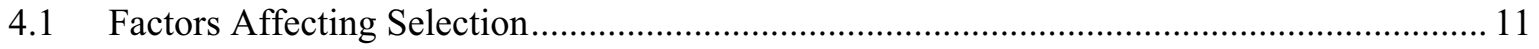

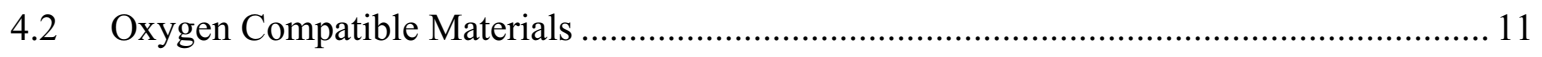

4.3 General Guidelines for Materials Selection .................................................................. 12

4.4 Metals for Low-Pressure Oxygen Service ................................................................... 12

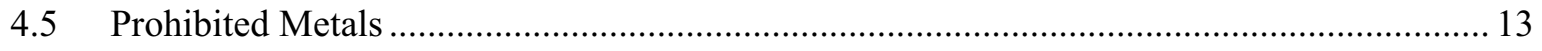

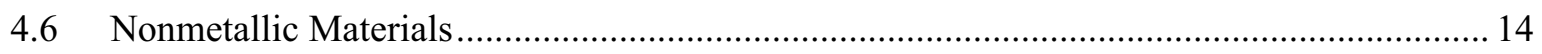

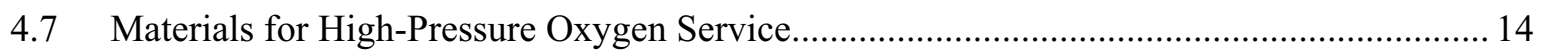

4.8 Selecting Material by Configuration Testing ............................................................... 14

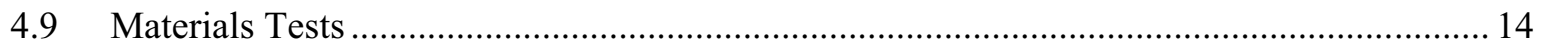

5. OPERATIONAL SAFETY AND PROTECTIVE MEASURES …......................................... 15

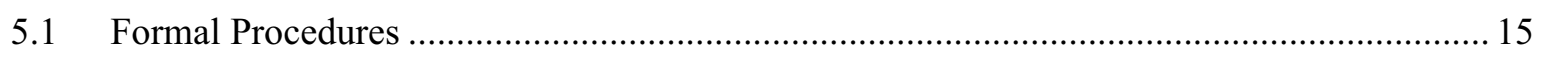

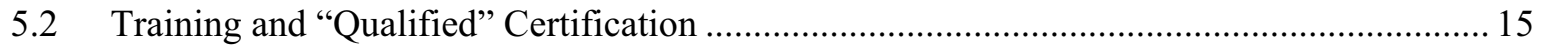

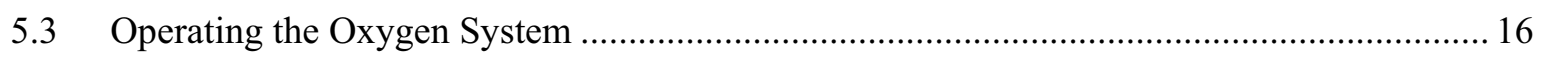

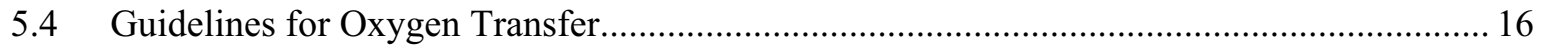

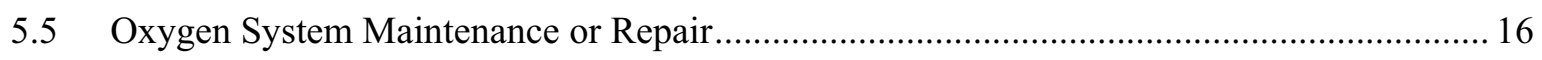

5.6 Operational Procedures for Liquid Oxygen Systems …................................................... 17

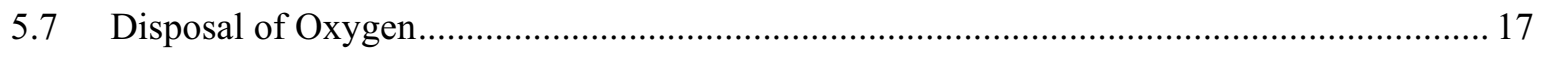

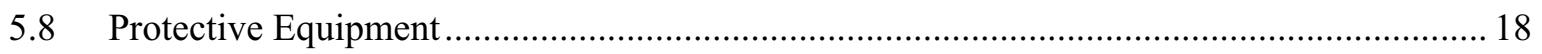




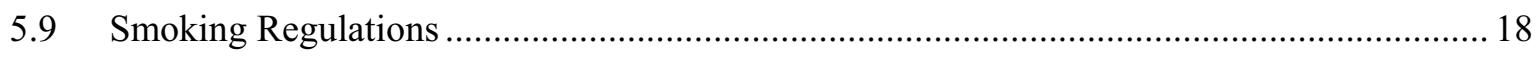

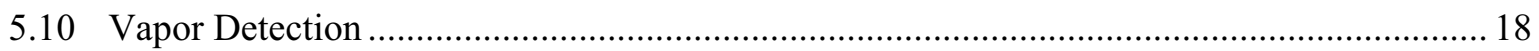

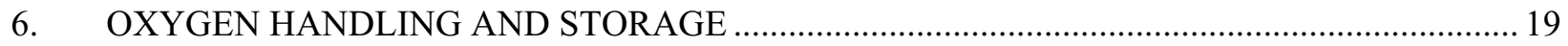

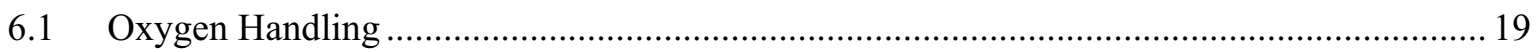

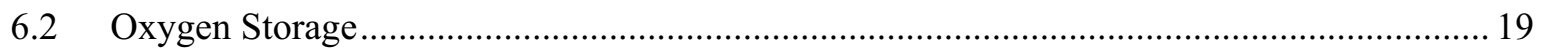

6.3 Quantity-Distance Guidelines for Gaseous Oxygen Storage ............................................ 20

6.4 Site and Equipment Design and Practice ......................................................................... 20

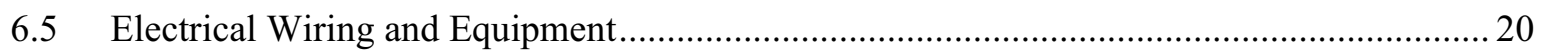

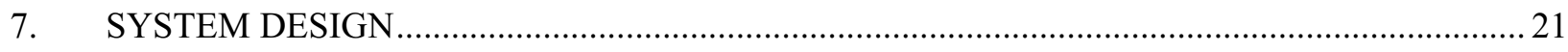

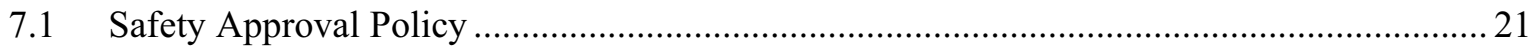

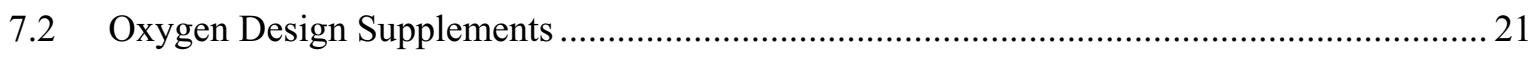

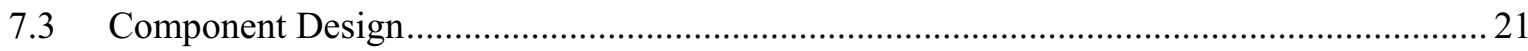

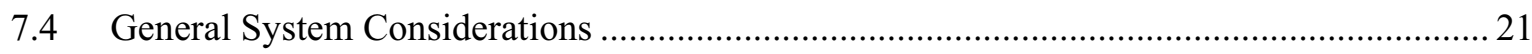

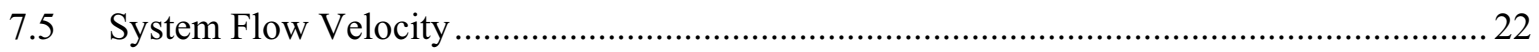

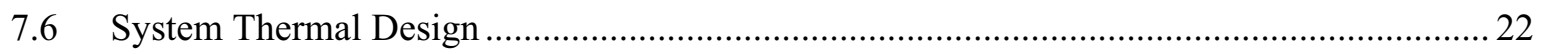

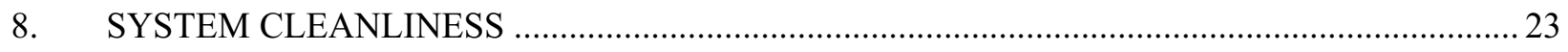

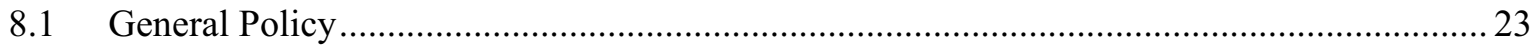

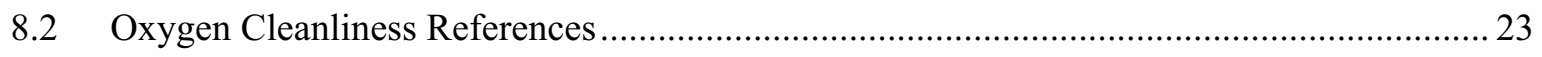

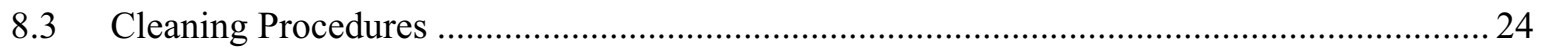

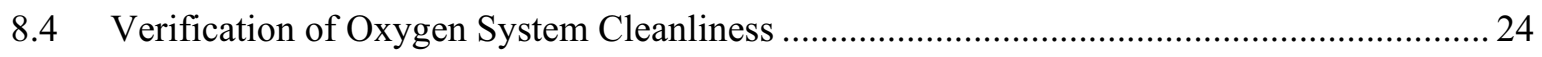

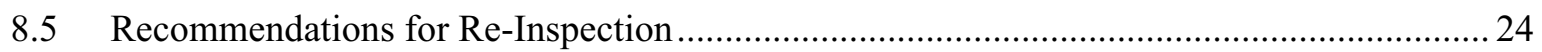

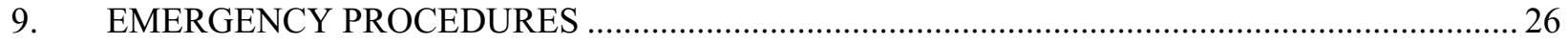

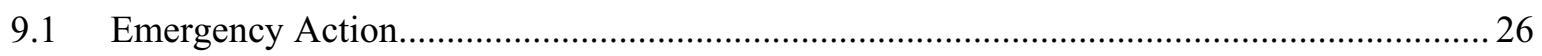

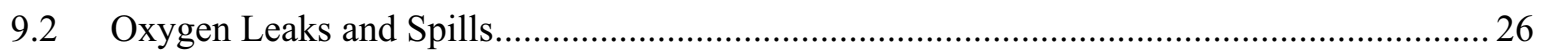

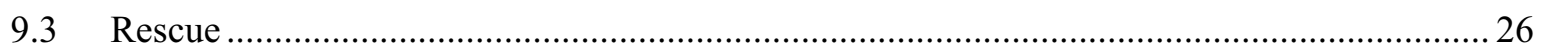

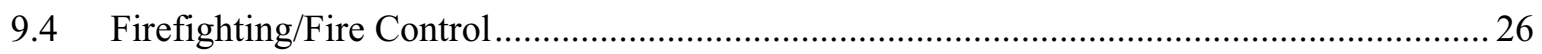

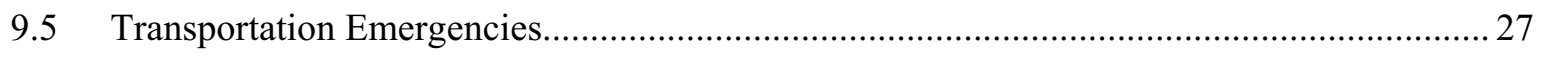

9.6 Decontamination of Oxygen and Fuel Mixtures Liquid ................................................. 27

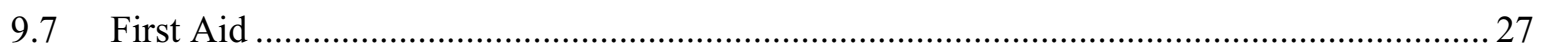

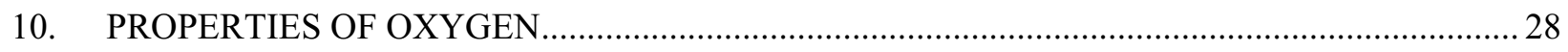

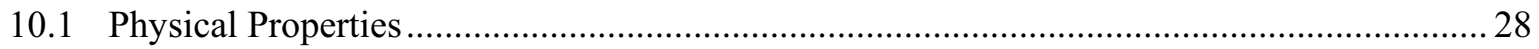

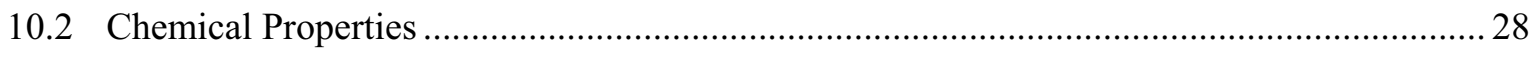

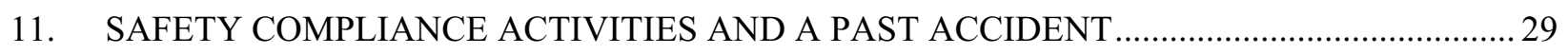

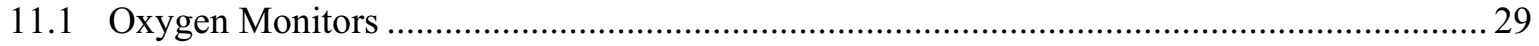

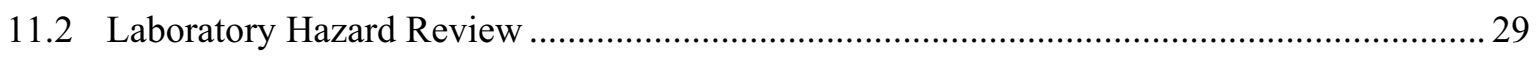

11.3 Canadian AEC Chalk River Accident Report .................................................................... 29

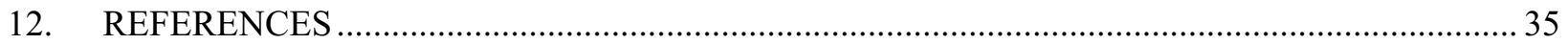


Appendix A-Monitoring for Combustible and Toxic Gases

Appendix B - INL Laboratory Instruction (Li) of the Hydrogen/Oxygen Generating Laboratory

System

\section{FIGURES}

Figure 1. Conceptual diagram of the INL hydrogen (and oxygen generating) plant ................................. 2

Figure 2. Schematic diagram of INL laboratory set-up to generate hydrogen and oxygen .........................2

Figure 3. Relationship between different flammability properties (Vidal Vázquez [3]). (Adapted from Bureau of Mines Bulletin [4]) ........................................................................ 4

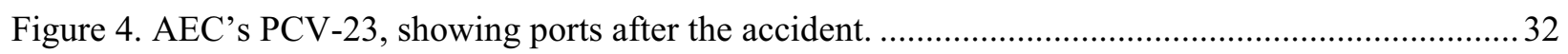

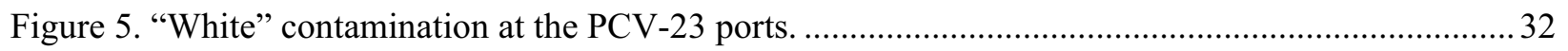

Figure 6. PCV-16 valve showing heavy combustion damage at the outlet port (shown lower) ................. 33

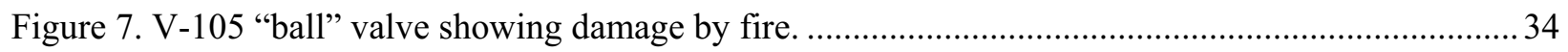

\section{TABLES}

Table 1. Classification of Flammability According to DOT and NFPA [2] ............................................. 6

Table 2. Some Recommended Materials for Oxygen Service ${ }^{\mathrm{a}}$ [7] ....................................................... 13

Table 3. Selected Safety-Relevant Physical Properties of Gaseous and Liquid Oxygen [21, 1] ...............28

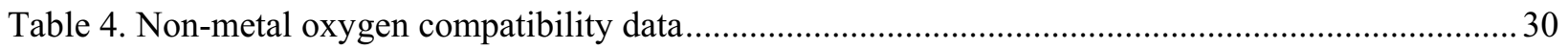




\section{Oxygen Handling and Cooling Options in High Temperature Electrolysis Plants}

\section{INTRODUCTION TO OXYGEN HANDLING}

Idaho National Laboratory (INL) is working on a project to generate hydrogen by high temperature electrolysis (HTE). A conceptual diagram of such a system is shown in Figure 1 . Steam at $\sim 830^{\circ} \mathrm{C}$ is electrolyzed in a solid oxide electrolyzer to produce hydrogen and oxygen. Figure 2 shows the concept in the laboratory setting. In such an HTE system, safety precautions need to be taken to handle high temperature oxygen at $\sim 830^{\circ} \mathrm{C}$. This report is aimed at addressing handling oxygen related to a HTE system.

Though oxygen itself is not flammable, most engineering materials, including many gases and liquids, will burn in the presence of oxygen under some favorable physicochemical conditions. The American Society for Testing and Materials (ASTM) and National Aeronautics and Space Administration (NASA) Glenn Research Center have developed safety manuals [1-2], all or part of which have been devoted to the safe handling of oxygen. These standards will be frequently cited in this report.

At present, an absolute set of rules does not exist that can cover all aspects of oxygen system design, material selection, and operating practices to avoid subtle hazards related to oxygen. Some oxygen systems give apparently normal service for decades before circumstances arise to yield an incident or fire. Because most materials, including metals, will burn in an oxygen-enriched environment, hazards are always present when using oxygen. For most materials, the ignition temperature in an oxygen-enriched environment is lower than in air, and once ignited, combustion rates are greater in this environment. However, these hazards do not preclude the operation of systems involving oxygen. Oxygen can be safely handled and used if all the materials in a system are not flammable in the end-use environment, or if ignition sources are identified and controlled. In fact, the incidence of oxygen system fires is reported to be low with a probability of about one in one million (ASTM Committee G4.05).

This report is a practical guide and tutorial for the safe operation and handling of gaseous oxygen in a high temperature electrolysis system to generate hydrogen. The intent is to provide safe, practical guidance that permits the accomplishment of experimental operations at INL, while being restrictive enough to prevent personnel endangerment and provide reasonable facility protection. More extensive safety precautions should be employed wherever possible. These guidelines should in no way be considered as relaxing and overriding any occupational safety or health standard imposed by other regulatory organizations and agencies. Where precisely quantifiable direction is not possible, oxygen system design, material selection, and operating practice guidelines are based on proven experience and logical technical judgment. A summary of operational hazards, along with oxygen safety and emergency procedures, are provided. 


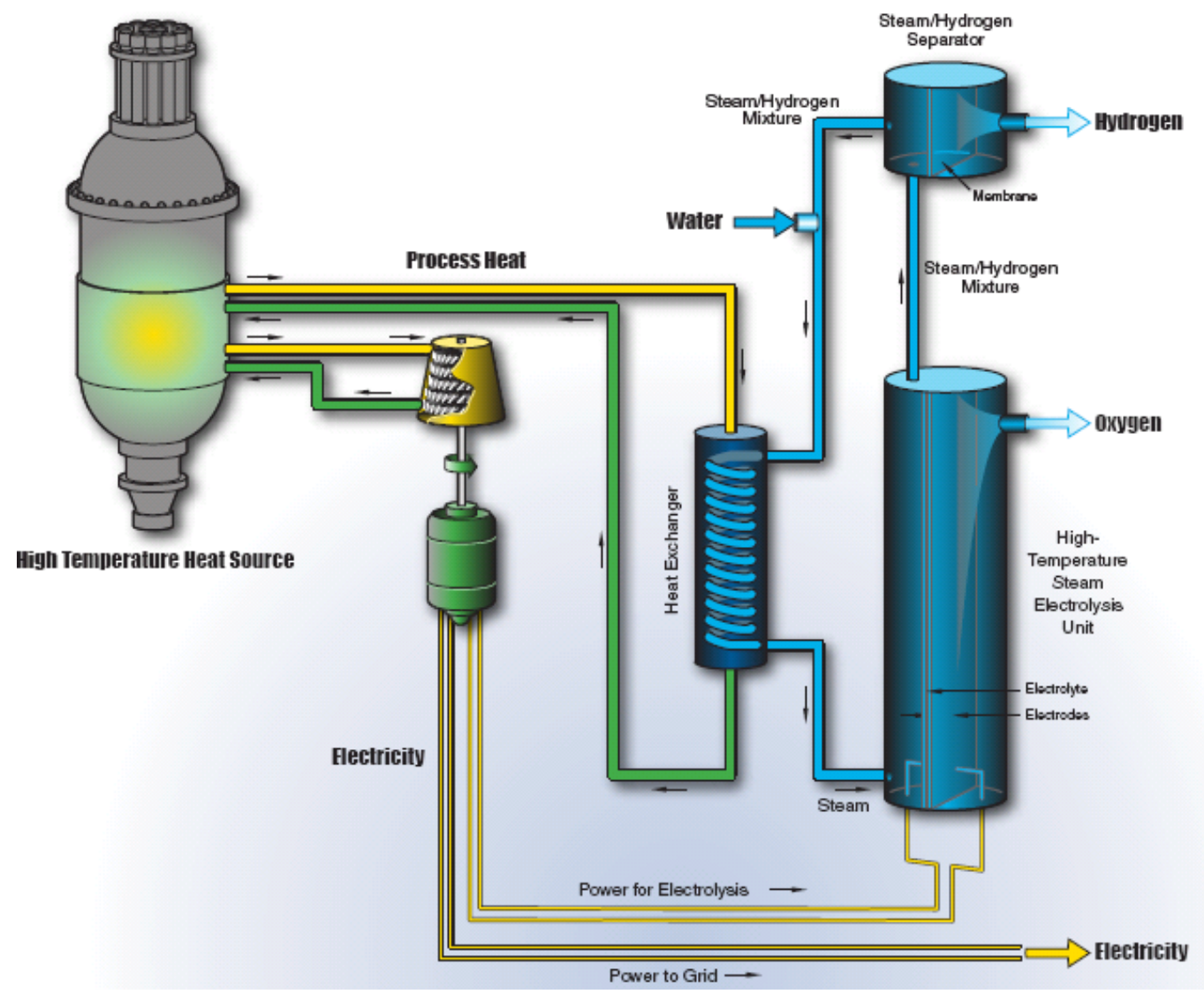

Figure 1. Conceptual diagram of the INL hydrogen (and oxygen generating) plant.

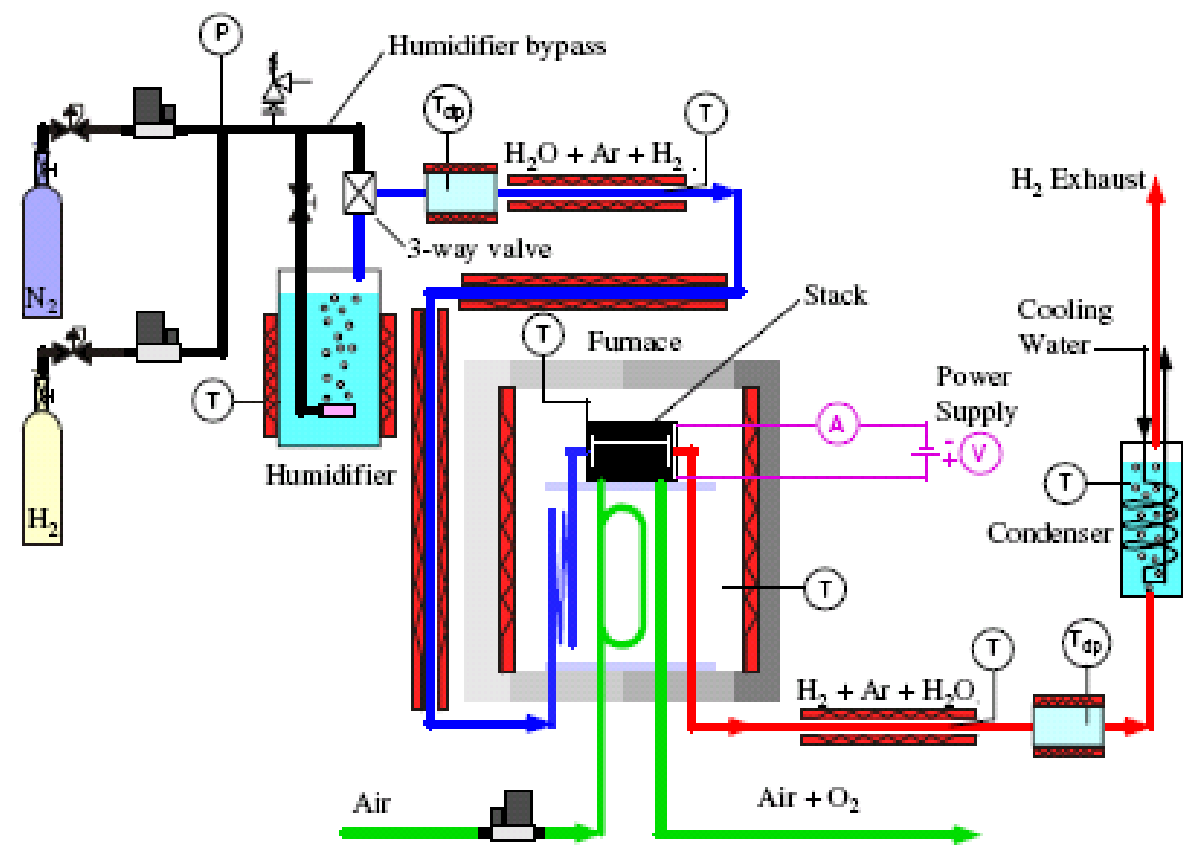

Figure 2. Schematic diagram of INL laboratory set-up to generate hydrogen and oxygen. 


\section{HAZARDS RELATED TO OXYGEN}

In this section, various hazards associated with oxygen, their causes, and their assessments are discussed.

\subsection{Hazards in Oxygen System}

ASTM MNL-36 [1] and Vidal Vázquez [3] have identified the major hazards in many industries as fire, explosion, and toxic release. Of these three, the most common is fire, but explosion is particularly devastating in terms of fatalities and property loss. Explosion can be a result of sudden release of built-up pressure. However, a fire can also eventually lead to explosions. A hazardous material can be defined as a substance that poses an unacceptable risk to health, safety, or property. Absolute safety can never be achieved due to the inherent properties of some materials and chemicals. Therefore, risk can only be reduced to an acceptable level. Hazards can be categorized by combustibility or flammability, volatility, toxicity, and reactivity. Hazard assessment is a thorough, orderly, and systematic approach for identifying, evaluating, and controlling hazards of processes involving chemicals. There are many organizations that have developed lists, definitions, and classifications related to flammable chemicals, including Department of Transportation (DOT), National Fire Prevention Association (NFPA), Occupational Safety and Health Agency (OSHA), and Environmental Protection Agency (EPA). Some organizations establish their classifications with qualitative descriptions, but most classifications are based on physical/chemical properties such as flash point $(T f)$ and boiling point $(T b)$.

\subsection{Parameters and Conditions Responsible for Hazards in Oxygen Handling}

Flammability/Ignition: Vidal Vázquez [3] has defined several terms related to oxygen flammability. There is not a single parameter that defines flammability, but some of the relevant properties are flash point (Tf), lower flammable limit (LFL), upper flammable limit (UFL), and auto-ignition temperature (AIT). The LFL and UFL are the minimum and maximum volumetric concentrations of fuel in air that set the endpoints of the flammability range. The LFL represents the initiating point of flame propagation, and the UFL represents the extinguishing point due to the shortage of oxygen or excess of fuel. The AIT is the minimum temperature required to cause self-sustained combustion. The flash point of a flammable liquid is the temperature at which the vapor pressure of the liquid provides a concentration of vapor in air that corresponds to the LFL. At a temperature called the fire point temperature (which is a few degrees above the flash point temperature, Tf) enough vapor is generated to be ignited. However, the flash point temperature is used by regulatory authorities to rate the flammability hazards of chemicals. Based on these ratings, specific regulations and guidelines for usage, transportation, and storage are developed. The relationship among these properties is presented in Figure 3. The degrees of flammability according to National Fire Prevention Association (NFPA) and US Department of Transportation (DOT) are presented in Table 1 [3].

Ignition occurs when a combustible material is heated to ignition temperature. The ignition temperature of a material in oxygen systems is not an absolute physical property, but it depends on many related parameters. As yet, no single test can be applied to all materials to give an absolute value of ignition temperature. In fuel-oxygen mixtures, lower energy input is needed for ignition as compared to the energy input needed in fuel-air mixture. For example, ASTM MNL-36 [1] gives minimum spark energy required for the ignition of hydrogen in air as $1.8 \times 10^{-8}$ Btu at $1 \mathrm{~atm}$, but only $1.1 \times 10^{-9} \mathrm{Btu}$ in an oxygen environment. Several potential sources may exist that can cause ignition of fuel-oxygen system. These sources are heat of compression, friction, heat from impact, other flame source, shock waves from a tank/pipe burst, hot exhaust from another source of heat, electrical ignition, electrical short circuit, spark, static electricity resulting from solid particle interaction, and build-up of electrical charge by various electrical components, etc. 


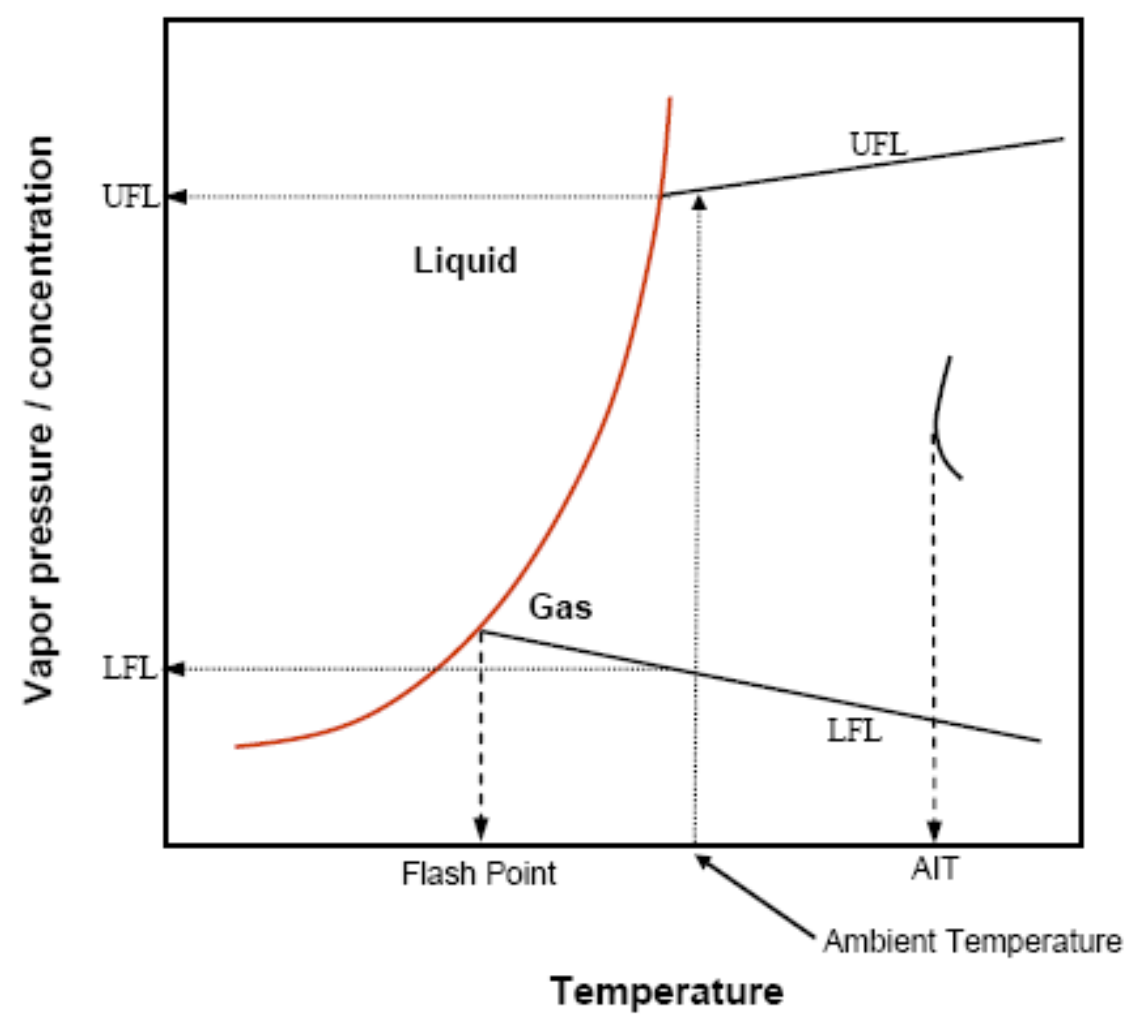

Figure 3. Relationship between different flammability properties (Vidal Vázquez [3]). (Adapted from Bureau of Mines Bulletin [4])

Flash Point: The flash point of a flammable liquid is the temperature at which the vapor pressure of the liquid provides a concentration of vapor in air that corresponds to the LFL [4]. It is assumed that the flash point is the temperature at which enough vapor has been generated to be ignited. The regulatory organizations consider the flash point as the critical parameter to rate the flammability hazards of fuels/chemicals. Based on these ratings, specific regulations and guidelines for usage, transportation, and storage of a fuel/chemical are developed. Liquid and gaseous oxygen must be stored, handled, and used so that life and health of the workers is not jeopardized and the risk of property damage is minimized.

Fire and explosion: Pure oxygen does not burn by itself, but makes fires burn faster and hotter. To prevent evolution of the enhanced fire, any location where oxygen is stored or used must be relatively free of flammable and combustible items. Examples of these materials include alcohols, solvents, petroleum products, and papers. Open flames, sparks, or high heat from smoking items, radiant heaters, and certain appliances must be controlled. The highest safe temperature for the oxygen tank and accessories is $125^{\circ} \mathrm{F}$.

Oxygen-supported combustion of most engineering materials is a potential fire hazard. Some oxygen systems have given apparently normal service for decades before circumstances combine to yield an incident or fire. Materials that burn very slowly or not at all can burn vigorously or even explosively in oxygen. For example, stainless steel and some other metals, Teflon, and silicones, which are generally regarded as fire resistant, can burn easily in oxygen under favorable conditions. Oil, grease, asphalt, kerosene, cloth, wood, paint, tar, and dirt can react violently with oxygen. Violent fires in high-pressure oxygen systems have resulted from component failures, entrained metal particles in the flowing gas system, and rapid metal-to-metal frictional contact within components. Leaking or spilled liquid oxygen can form dangerously high concentrations of oxygen gas. In an oxygen-rich environment, clothing may become saturated with oxygen, ignite readily, and burn violently. 
Hazards of Cryogenic Oxygen and Oxygen Mixing with other Gases: There are health hazards associated with very low temperatures of liquid oxygen. Frostbite results when such a liquid or a noninsulated pipe containing it contacts the skin. The use of cryogenic oxygen can cause additional design and exposure problems, such as trapped cryogenic fluids developing explosive high pressure rupture potentials, oxygen-saturated clothing, cryogenic flesh burns, impact ignitions, and numerous other concerns. When liquid oxygen is trapped in a closed system and refrigeration is not maintained, pressure rupture may occur. Oxygen cannot be kept liquid if its temperature rises above the critical temperature of $-181.4^{\circ} \mathrm{F}(154.6 \mathrm{~K})$.

Inhalation of argon or nitrogen mixed with oxygen can even cause death. Breathing pure oxygen for limited periods of time (an hour or two) will not have any toxic effects; however, the upper respiratory tract may become irritated if the gas is very dry. Very low temperatures of liquid oxygen can assist in trapping foreign matter and impurities that may react with oxygen at a later time.

If odorless and colorless gases or hydrocarbons inadvertently dissolve in oxygen, several problems can occur. If oxygen and a flammable gas are ignited, the reaction may proceed violently, even explosively. 
Table 1. Classification of Flammability According to DOT and NFPA [2].

\begin{tabular}{|c|c|c|c|c|c|}
\hline & Purpose & Flammability Definition & \multicolumn{3}{|c|}{ Classification } \\
\hline \multirow[t]{2}{*}{ DOT } & $\begin{array}{l}\text { Transportation } \\
\text { Regulates }\end{array}$ & $\begin{array}{l}\text { Flammable liquid is any liquid } \\
\text { with } \mathrm{T}_{\mathrm{f}}<141^{\circ} \mathrm{F}\left(60.5^{\circ} \mathrm{C}\right) \text {. } \\
\text { Combustible liquid is }\end{array}$ & \multicolumn{3}{|c|}{$\begin{array}{l}\text { Class } 3 \text { flammable liquids are defined as liquids having a } T_{f} \text { of not more } \\
\text { than } 141^{\circ} \mathrm{F}\left(60.5^{\circ} \mathrm{C}\right) \text { or any material in a liquid phase with a } T_{f} \text { at or above } \\
100^{\circ} \mathrm{F}\left(37.8^{\circ} \mathrm{C}\right) \text {. }\end{array}$} \\
\hline & $\begin{array}{l}\text { Regulates } \\
\text { transportation }\end{array}$ & & $\begin{array}{l}\text { NFPA } 30^{3,6} \\
\text { Classification }\end{array}$ & $\begin{array}{l}\text { NFPA } 704^{c} \\
\text { Hazard } \\
\text { Rating }\end{array}$ & Liquid Definition \\
\hline \multirow[t]{5}{*}{ NFPA } & \multirow[t]{2}{*}{$\begin{array}{l}\text { Fire-fighting and fire } \\
\text { protection }\end{array}$} & \multirow{2}{*}{$\begin{array}{l}\text { A liquid is classified as } \\
\text { flammable if it has a } \mathrm{T}_{f} \text { of } 100^{\circ} \mathrm{F} \\
\text { or lower, when tested by closed } \\
\text { cup methods. }\end{array}$} & IA & 4 & $\mathrm{~T}_{\mathrm{f}}<73^{\circ} \mathrm{F}\left(22.8^{\circ} \mathrm{C}\right) ; \mathrm{T}_{\mathrm{b}}<100^{\circ} \mathrm{F}\left(37.8^{\circ} \mathrm{C}\right)$ \\
\hline & & & IB, IC & 3 & $\begin{array}{l}\mathrm{T}_{\mathrm{f}}<73^{\circ} \mathrm{F}\left(22.8^{\circ} \mathrm{C}\right) ; \mathrm{T}_{\mathrm{b}} \geq 100^{\circ} \mathrm{F}\left(37.8^{\circ} \mathrm{C}\right) \\
100^{\circ} \mathrm{F}\left(37.8^{\circ} \mathrm{C}\right)>\mathrm{T}_{\mathrm{f}} \geq 73^{\circ} \mathrm{F}\left(22.8^{\circ} \mathrm{C}\right)\end{array}$ \\
\hline & \multirow{3}{*}{$\begin{array}{l}\text { NFPA standard } \\
\text { referenced by OSHA }\end{array}$} & \multirow{3}{*}{$\begin{array}{l}\text { Combustible liquids are those } \\
\text { with } \mathrm{T}_{\mathrm{f}} \text { higher than } 100{ }^{\circ} \mathrm{F}(37.8 \\
\left.{ }^{\circ} \mathrm{C}\right)\end{array}$} & II & 2 & $140^{\circ} \mathrm{F}\left(60^{\circ} \mathrm{C}\right)>\mathrm{T}_{\mathrm{f}} \geq 100^{\circ} \mathrm{F}\left(37.8^{\circ} \mathrm{C}\right)$ \\
\hline & & & IIIA & 2 & $200^{\circ} \mathrm{F}\left(93.3^{\circ} \mathrm{C}\right) \leq \mathrm{T}_{\mathrm{f}} \geq 140^{\circ} \mathrm{F}$ \\
\hline & & & IIIB & 1 & $\mathrm{~T}_{\mathrm{f}}>200^{\circ} \mathrm{F}\left(93.3^{\circ} \mathrm{C}\right)$ \\
\hline
\end{tabular}

NFPA 30: Flammable and Combustible Liquids Code

"The OSHA classifications are the same as those in NFPA 30 (Scheffey et al., 1996). ${ }^{14}$

'NFPA 704: Standard System for the Identification of the Fire Hazards of Materials 


\subsection{Hazard Assessment}

It is suggested in ASTM MNL-36 [1] that a hazard assessment should be performed on any component or system intended for oxygen service in a thorough, orderly, and systematic manner for identifying, evaluating, and controlling hazards of processes involving oxygen or any other chemical. To perform an experiment or implement a process using oxygen systems, the operator must define, develop, document, implement, and maintain necessary policies and procedures to govern and control all phases of a product or systems that involve the use of oxygen. The hazards analysis should include review of the system design, component design, installation, operating procedures, protective measures, in-service inspection requirements and maintenance procedures, cleaning, service, decommissioning, and emergency procedures. Safety of an experiment or a process using oxygen can be considerably increased by adopting and instituting practices that have been developed and used successfully by the developers of ASTM MNL36 [1]. The hazards analysis should perform the following activities:

- Determine the most severe operating conditions

- Evaluate flammability of materials at the operating conditions

- Evaluate ignition sources

- Compare the above to existing data and perform configurational and component tests if required to determine and demonstrate safety margins to ignition thresholds.

The hazards analysis should consider the most severe operating conditions and their effects upon the system. It should include the effect of operational anomalies and single-point failure modes such as ignition, combustion, explosion, or the effect of oxygen enrichment of a normally ambient environment. The following operating parameters define some of the conditions relevant to the hazards in an oxygen system [1]:

- Temperature

- Pressure

- Oxygen concentration

- Flow velocity

- Frictional related parameters (load, speed)

- Multiple duty cycles.

All oxygen system components must be evaluated in the worst possible scenario. If the most severe single point condition cannot be determined in terms of material ignition and flammability, then the range of operating conditions must be considered. The flammability of the materials used in the oxygen system shall be evaluated. If a material is not flammable, then it may be used safely even if ignition sources exist. If the material is flammable and if no ignition source exists, the material may still be used safely.

However, if an ignition source exists, the materials and designs should be compared to available data to determine safety margins to the ignition thresholds of the material. Potential ignition sources shall be evaluated to ensure no hazards exist that could cause an unacceptable risk to personnel, property, or system objective. Potential ignition sources should be eliminated through engineering design wherever feasible. 


\section{HAZARD ELIMINATION/MINIMIZATION}

Several steps should be taken to achieve maximum oxygen safety. The primary consideration for resolving oxygen hazards shall be to eliminate them by proper design. The generally accepted steps in the design process, including design, quality, and acceptance testing, are provided in Chapter 4 of ASTM MNL-36 [1]. Some of the system design ideas are taken from NASA safety manual [2]. Hazards that cannot be eliminated by design should be controlled by taking the following corrective actions in this order of precedence:

- Design for minimum hazard and allow for verification of cleanliness to the required level

- Install safety devices

- Install alarms and warning devices

- Develop administrative controls, including special procedures and training

- Provide protective clothing and equipment.

When hazards are reduced or eliminated in a plant, the process not only becomes safer, but also emissions to the environment are reduced or eliminated. Environmental damage resulting from the release of chemicals/gases during an incident can be significantly reduced. In general, any liquid with flash point or boiling point temperatures lower than ambient temperature constitutes a major fire hazard than a liquid with values above ambient temperature.

\subsection{Inherently Safe Design}

Oxygen systems should be designed by selecting materials that are ignition and combustion-resistant at the most severe operating conditions. Safe oxygen systems must include designs for preventing leaks, eliminating ignition sources, establishing and maintaining a clean system, avoiding cavitation (in liquid oxygen systems), and preventing resonant vibration. Vidal Vázquez [3] has provided guidelines for an inherently safe design approach to remove or reduce hazards at the source, instead of controlling them with add-on protective barriers. However, for an oxygen system under consideration, one principle that can make a significant difference is to design the system in order to minimize the effects of the release of hazardous chemicals or energies. The principle of inherent safety that best applies to flammable mixtures is "substitution," which implies replacing a hazardous substance by a less hazardous one. The flash point of a mixture is a function of composition and its behavior is highly dependent on the individual components of the mixture. Therefore, substituting one of the components of the mixture will affect the flash point of the mixture. Flammability measures the potential to generate fire and explosions, and flash point is the flammability property used to classify or categorize flammable liquids. The flash point of a mixture varies with composition, and its behavior strongly depends on the components of the mixture. Therefore, by changing one of the components of the mixture, the flash point of the mixture is modified.

\subsection{Two Safety Barriers}

At least two failure-resistant, independent barriers shall be provided to prevent a given failure from escalating into a major disaster. Thus, at least two independent failures have to occur simultaneously before there would be a potential danger to personnel or a major disaster.

\subsection{Fail-Safe Design}

The equipment, power, and other system services shall be designed and verified for safe performance in the normal and severe operational conditions. The design should be such that if there is a failure, the 
system should revert to operating conditions that are safe for the personnel and will cause the least property damage. Additional components may need to be incorporated into the design to prevent system failure.

\subsection{Automatic Safety Devices}

System safety valves, flow regulators, and equipment safety features shall be installed to automatically control hazards.

\subsection{Alarms and Warning Systems}

Instrumentation to monitor the parameters relating to the storage, handling, and use of oxygen that may endanger personnel and cause property damage should be incorporated into oxygen system design. There should be warning systems if these parameters reach the unsafe zone. Warning systems shall consist of sensors to detect abnormal conditions, measure malfunctions, and indicate incipient failures. Data transmission systems for caution and warning systems shall have sufficient redundancy to prevent any single-point failure from failing an entire system.

\subsection{Formal Procedures}

All oxygen operations and procedures shall be performed by technically knowledgeable and formally trained personnel. Personnel involved in design and operations will carefully adhere to the safety standards and must comply with regulatory codes. System cleaning procedures shall be adopted from proven methods successfully used in industry or at INL.

\subsection{Personnel Training}

Personnel assigned to handle/use oxygen or to design equipment for oxygen systems must become thoroughly familiar with the physical, chemical, and hazardous properties of oxygen.

\subsection{Operator Certification}

Operators shall be certified (per institutional requirements) to handle liquid and gaseous oxygen under normal and emergency conditions.

\subsection{Safety Review}

All oxygen design, handling, and test operation activities shall be subject to an institutional independent safety committee review and subject to a permit issued by the responsible safety committee. In addition, any modification to an oxygen handling system or research laboratory shall be brought to the attention of the appropriate safety committee for review prior to operation.

\subsection{Reducing the Probability of the Oxygen Hazard}

The severity of oxygen hazard can be minimized by reducing the severity of the system's operating parameters and using materials and designs best able to withstand the oxygen environment. Because so many parameters influence the choice of the material for oxygen-service, several possibilities exist. Therefore, using as many as possible of the following steps in concert minimizes the overall probability of a significant incident (ASTM Committee G4.05):

- Maintain cleanliness 
- Adopt safe operating practices, such as opening valves slowly and using valves with higher flow control capacity to limit downstream pressurization rates

- Isolate or shield the hardware to reduce personnel exposure to the oxygen system

- Minimize flow velocity (by using larger diameter flow conduits)

- Use fire-resistant materials that improve the system's susceptibility to fire hazard. Materials used in oxygen service should be selected based on the following criteria:

- Materials with high ignition temperatures and high ignition impact thresholds

- Materials resistant to flame propagation

- Materials with lower thermal conductivity and thermal diffusivity, thus having reduced potential for damage. 


\section{MATERIALS}

Safe use of oxygen requires the control of potential ignition energy mechanisms within oxygen systems by judiciously selecting ignition-resistant materials and system designs maintaining scrupulously clean systems, and using appropriate operational procedures. Oxygen can react with nearly all materials that are not already fully oxidized. The following criteria are given by NASA [2], ASTM MNL-36 [1], and European Industrial Gas Association [22].

\subsection{Factors Affecting Selection}

For selection of a material for use with oxygen, the circumstances that cause oxygen to react with the material need to be understood. Most materials in contact with oxygen will not ignite without a source of ignition energy. When energy input exceeds the configuration-dependent threshold, ignition and combustion may occur. Therefore, safe use of oxygen requires the control of potential ignition energy mechanisms within oxygen systems by judiciously selecting ignition-resistant materials. Ignition mechanisms which can result in pipeline failures include:

- Particle impact ignition caused by impingement of metallic or non-metallic materials with the metal components of the pipeline

- Adiabatic compression, acoustic resonance and flow friction, which create temperature increase

- Ignition initiated by the combustion of organic materials, or contaminants entrained in the oxygen flow

- Friction caused by rubbing, as in a valve between adjacent moving and stationary parts

- Electric arcing between metallic components due to static electricity or lightning which generates enough energy to ignite metallic or non metallic materials.

When the ignition mechanism has started, the combustion can propagate through the kindling chain. Once ignited, the combustible material or component generates heat, which can, depending on many factors, ignite the bulk material of the pressure envelope. The rate and extent of the propagation of the fire along the pressure envelope will depend on the thickness and the flammability of the material. The use of exempt materials will limit the propagation of the combustion by interrupting the kindling chain. The rate and extent of the propagation of the fire is also influenced by oxygen parameters such as pressure, purity, temperature, and the total oxygen inventory available to support combustion. For pressures below 30 psig ( $0.21 \mathrm{MPa})$, experimental data show that the combustion rates of potential materials used in oxygen pipeline components such as carbon steel are very low and decrease with decreasing pressure. This effect has contributed to the excellent service experience demonstrated by properly designed carbon steel components in selected very low pressure oxygen applications. Many causes of fire can be avoided and their consequences reduced by effective design practices. Other causes of fire may be due to unsuitable maintenance and operating practices, such as:

- Overheating due either to a process failure or to an oxygen leakage from the system resulting in an external fire adjacent to the pipeline

- Accidental mixing with fuel, due to either a process failure or contaminant introduction during maintenance work.

\subsection{Oxygen Compatible Materials}

Major progress has been made toward enabling oxygen systems to be compatible with higher pressures, temperatures, etc. by designing the oxygen systems that protect or shield the more susceptible 
nonmetallic components from direct interface with oxygen Bond et al. [7]. Combustion resistant alloys are engineering alloys which, after being subjected to an ignition event, will not burn or exhibit combustion quenching behavior, resulting in minimal material consumption. Examples of engineering alloys, which are highly combustion resistant, are copper, pure nickel, and Monel. Depending upon oxygen pressure, oxygen purity, temperature and configuration, other engineering alloys such as stainless steel may exhibit varying degrees of combustion resistance.

\subsection{General Guidelines for Materials Selection}

The final selection of a material for an oxygen application is an optimized tradeoff between the chemical compatibility, the ignition and combustion characteristics, the physical properties of the material, the cost, and the consequences of a failure. Proper material choices can markedly reduce the probability of system ignition. Materials selected for cryogenic oxygen service shall have the required structural ductility and notch sensitivity characteristics. References [1, 7-10, 22] provide detailed discussion on material selection.

\subsection{Metals for Low-Pressure Oxygen Service}

Gaseous oxygen: Metals recommended for low-pressure (nominally less than 1000 psia) gaseous oxygen service include:

- Aluminum - nickel

- Aluminum alloys - nickel alloys

- Copper - stainless steel

- Copper alloys.

Liquid oxygen: Metals recommended for service with liquid oxygen are:

- Nickel and nickel alloys

- Hastelloy B - nickel

- Inconel-X - Rene 41

- K-Monel

- Stainless steel types

- $304-310$

- $\quad 304 \mathrm{~L}-316$

- 304ELC - 321

- Copper and copper alloys

- Copper - Cupro-nickel

- Naval brass

- Admiralty brass.

A summary of recommended materials for oxygen system application is given in Table 2 . 
Table 2. Some Recommended Materials for Oxygen Service ${ }^{\mathrm{a}}$ [7].

\begin{tabular}{|c|c|c|}
\hline Application & Low pressure ${ }^{\mathrm{b}}$ & High pressure $^{\mathrm{c}}$ \\
\hline Component bodies & Nickel alloy steel, Stainless steel & Monel Inconel 718 \\
\hline Tubing and fittings & $\begin{array}{l}\text { Copper, Stainless steel, Steel, Aluminum } \\
\text {,Aluminum alloys }\end{array}$ & Monel Inconel 718 \\
\hline Internal parts & Stainless steel & $\begin{array}{l}\text { Monel Inconel 718, Beryllium } \\
\text { copper }\end{array}$ \\
\hline Springs & Stainless steel & $\begin{array}{l}\text { Beryllium copper, Elgiloy, } \\
\text { Monel }\end{array}$ \\
\hline Valve seats & Stainless steel & $\begin{array}{l}\text { Gold or silver plated over } \\
\text { Monel or Inconel } 718\end{array}$ \\
\hline Valve balls & Stainless steel,, Tungsten carbide & Sapphire \\
\hline Lubricants & $\begin{array}{l}\text { Everlube } 812 \text {, Microsel } 100-1 \text { and } 200-1 \text {, } \\
\text { Triolube } 1175 \text {, Krytox } 240 \mathrm{AB} \text {, and } 240 \mathrm{AC} \\
\text { Braycote 3L-38RP }\end{array}$ & $\begin{array}{l}\text { Batch/lot-tested Braycote 3L- } \\
\text { 38RP, Batch/lot- tested } \\
\text { Everlube } 812, \text { Krytox } 240 \mathrm{AC}\end{array}$ \\
\hline O-seals and backup & TFE, Halon, TFE Teflon, Kel F, Viton & $\begin{array}{l}\text { Batch/lot-tested Viton } \\
\text { Batch/lot-tested Teflon }\end{array}$ \\
\hline Pressure vessels & $\begin{array}{l}\text { Nickel steel, Stainless steel, Steel, Aluminum } \\
\text { alloys }\end{array}$ & Inconel 718 \\
\hline \multicolumn{3}{|c|}{$\begin{array}{l}\text { a. This table lists materials for conservative design standards. Materials listed in the "Low pressure" column and other } \\
\text { materials that are not listed may be suitable for more extreme environment oxygen service. Careful engineering analysis } \\
\text { and rationale shall be used to select alternate materials. } \\
\text { b. Nominally less than } 1000 \text { psi. } \\
\text { c. Nominally greater than } 1000 \text { psi. }\end{array}$} \\
\hline
\end{tabular}

\subsection{Prohibited Metals}

Certain metals are prohibited from being used in oxygen systems [1]. Some of these are given below.

Cadmium: The toxicity and vapor pressure of cadmium restrict its use.

Titanium: Titanium metal shall not be used with liquid oxygen at any pressure or with gaseous oxygen or air at oxygen partial pressures above 30 psia. Titanium and its alloys are impact sensitive in oxygen.

Magnesium: Magnesium metal also should not be used in oxygen systems, and its alloys should only be used in areas with minimal exposure to corrosive environments. Reactivity with halogenated compounds constrains its use with lubricants containing chlorine and fluorine.

Mercury: Mercury must not be used in oxygen systems in any form because it is toxic. It and its compounds can cause accelerated stress cracking of aluminum and titanium alloys.

Beryllium: Beryllium, its oxides, and salts are highly toxic and therefore must not be used in oxygen systems or near oxygen systems where they could be consumed in a fire. 


\subsection{Nonmetallic Materials}

The primary concerns with using nonmetals in oxygen systems are their potential reaction with oxygen at the cryogenic temperatures. Their ignition temperatures are generally lower than those for metals, and their low thermal conductivity and heat capacity make them much easier to ignite. The selection of these materials for use in oxygen is based on experience and testing of impact, ignition, and flammability characteristics. References [1 and 11] can provide more information on nonmetallic materials. Nonmetals that have been used successfully are:

- Tetrafluoroethylene polymer (TFE, Halon TFE, Teflon, or equivalent)

- Unplasticized chlorotrifluoroethylene polymer (Kel F, Halon CTF, or equivalent)

- Fluoro-silicone rubbers and fluorocarbons (Viton $\left.{ }^{\circledR}\right)$, batch-tested for acceptability (Viton $®$ is a registered trademark of Dupont Dow Elastomers)

- Lubricants such as Krytox (DuPont) and Triolube 16 (Aerospace Lubricants).

Table 2 contains a partial list of nonmetals and their applications.

\subsection{Materials for High-Pressure Oxygen Service}

The materials listed in Table 2 have demonstrated superior resistance to ignition and fire propagation in high pressure, nominally greater than $1000 \mathrm{psi}$, oxygen systems.

\subsection{Selecting Material by Configuration Testing}

If previously untested design material is proposed for a component, its suitability can be demonstrated through configuration (an identical proposed hardware) testing at conditions more severe than the worstcase environment for the component in question. The configuration tests should use oxygen pressures at least 10 percent above the worst-case condition. Expected temperature limits should be exceeded by at least $50^{\circ} \mathrm{F}$. If the material is to be subjected to rapidly changing pressures, the pressure rise rate used in the configuration tests should be at least twice that which the component is expected to experience in operation. If cycling or multiple reuse of the component is a design requirement, the configuration testing should exceed by a factor of four the expected number of cycles or reuses. Failure of the configuration test article before completion of the required number of cycles would limit the useful life of the component to one-fourth the number of cycles actually completed before failure.

\subsection{Materials Tests}

If a designer chooses a material that has not been previously approved or evaluated for oxygen service, rationale, procedures, and data as presented in the references $[9,12]$, it shall be provided to the institutional Safety Committee for approval. 


\section{OPERATIONAL SAFETY AND PROTECTIVE MEASURES}

To operate an oxygen system safely, all potential ignition energy sources within oxygen systems must be controlled by using appropriate and safe operational procedures. This section is based on the corresponding section in NASA Glenn Safety Manual [2].

\subsection{Formal Procedures}

All oxygen operations shall be conducted by knowledgeable and trained personnel using procedures that are written and documented. Standard operating procedures (SOPs) with checklists shall be developed for all the operations. The SOPs shall be prepared by individuals familiar with the work being done and shall be reviewed and implemented by the appropriate authority and approved by the institutional Safety Committee. Safety documentation should describe the operational safety, system inspections, training, safety related communications, and prevention of hazards. Special procedures shall be developed to eliminate hazardous conditions when the system design and the use of safety equipment alone are not enough to reduce a potential hazard to an acceptable level.

All operations involving the handling of oxygen shall be performed by at least two people (as a "buddy system"). Other safety measures are as follows:

- All operations involving oxygen shall be conducted by knowledgeable and trained personnel following formal written procedures

- Operators shall be certified as "qualified"

- Consideration for the safety of personnel at and near oxygen system must start in the earliest planning and design stages.

\subsection{Training and "Qualified" Certification}

Operator training shall familiarize personnel with the nature of the facility's major process systems. Major systems include loading and storage systems; purge gas piping systems; control, sampling, and analyzing systems; alarm and warning signal systems; ventilation systems; and fire and personnel protection systems. Personnel who handle or use liquid and gaseous oxygen or who design equipment for oxygen systems must become familiar with its physical, chemical, and hazardous properties. In addition, the following requirements apply:

- Personnel must become familiar with materials compatibility of oxygen, cleanliness requirements, procedures for handling spills, and recognizing the system limitations and failures.

- Training should include instruction on how to use the protective equipment and clothing. Fire drills and safety meetings shall be held regularly.

- Personnel must constantly reexamine procedures and equipment to be sure that safety has not been compromised by changes in test methods, over-familiarity with the system, equipment deterioration, or mechanical stresses due to abnormal operating conditions.

- Trained supervision of all potentially hazardous activities involving liquid oxygen is essential. Everyone working with these materials must abide with the first aid procedures described elsewhere in this document. Personnel shall be instructed to call 911 or other designated emergency phone number) for all emergency aid.

Operators shall be certified as "qualified" for handling oxygen and "qualified" in the emergency procedures for handling leaks and spills. "Qualified" operators should demonstrate: 
- Knowledge of the properties of liquid and gaseous oxygen

- Knowledge of approved materials that are compatible with liquid and gaseous oxygen under operating conditions

- Knowledge of proper equipment and proficiency in its operation

- Familiarity with equipment operations

- Proficiency in the use of protective equipment and clothing, and safety equipment

- Knowledge of first aid and proper emergency actions

- Ability to maintain clean equipment and clean oxygen system

- Knowledge of normal operations and ability to recognize associated abnormalities.

\subsection{Operating the Oxygen System}

Only authorized and "qualified" personnel shall operate the oxygen system after determining that the system is safe to operate. Personnel should be warned of combustible or explosive mixtures and high or low oxygen concentrations by detectors, sensors, and continuous sampling devices that operate both audible and visible alarms.

\subsection{Guidelines for Oxygen Transfer}

In the high temperature electrolysis laboratory experiments, oxygen will not be transferred or transported to another location as one might expect in a commercial plant. Therefore, if laboratory operation requires transportation of oxygen, following general guidelines should apply to both gaseous and liquid oxygen operations.

- Laboratory facility, transfer, and storage areas should be kept neat and free from combustibles and should be inspected frequently. An adequate water supply should be available for emergency fire fighting.

- The transfer equipment and its operation will be determined by local cognizant authority or the equipment manufacturer.

- Before starting transfer and flow operations, the oxygen system will be cleaned as required by the safety procedures.

- The oxygen system shall be periodically inspected for contamination and for elimination of unsafe conditions.

- Introducing the once-used oxygen back into the supply line may contaminate the system. Venting once-used oxygen is a preferred procedure.

\subsection{Oxygen System Maintenance or Repair}

The oxygen system shall be cleaned when it is opened for maintenance or repair. The following steps must be taken:

- Isolate, insofar as possible, the portion of the system to be cleaned and/or repaired.

- Drain, depressurize, and purge the oxygen system with an inert gas before opening it up.

- Leakage of contaminated air into the oxygen system must be avoided, especially if a part of the system is nitrogen jacketed. A slight positive pressure or purge may be necessary to avoid the system from "breathing." 
- Cap or seal any openings of a part prior to reinstalling it in the system.

- Purge and re-clean repaired parts prior to reinstallation in the system.

The oxygen system should be designed to avoid contaminant traps, which should be periodically cleaned. When working on equipment where oxygen enrichment is a possibility, isolate the equipment by inserting a blank. A shutoff valve is not considered a positive means of isolation from a working oxygen system.

\subsection{Operational Procedures for Liquid Oxygen Systems}

Specific operational check sheets shall be prepared by the design and operations team and approved by the Safety Committees. The operations sheets shall include the following elements in the general operating procedure for liquid system. High temperature electrolysis system at INL does not have liquid oxygen at any stage of the process. Therefore, this sub-section is for general information only.

Leak-check the system: Before operating a liquid oxygen system for the first time, cold-shock the entire system with clean liquid nitrogen and then check for leaks. Before loading the system with liquid oxygen, purge the system of air and water vapor. Recheck for cleanliness to be sure that cold shocking and leak checking did not contaminate the system.

Loading: Fill the system with liquid oxygen gradually to limit "geysering," severe local temperature gradients, and surges in the system.

Operations: Do not proceed with testing until the system has reached thermal equilibrium.

Shutdown: Purge the oxygen residue from all components of the system.

Unloading and transfer leaks: Leaks are usually caused during loading and unloading by deformed seals or gaskets, valve misalignment, or failures of flanges and equipment.

System leak repair: Relieve the system of any pressure, clean all the fittings and tools, making the system inert before performing any repairs or welding or brazing.

Condensation of contaminants during loading: Improper loading procedures for cryogenic oxygen can result in condensation of water or any other condensable vapor inside the system. Before loading a cryogenic system, purge or evacuate from the system all air, water, and condensable vapors, because even contaminant levels of few parts per million can produce a sizable frozen mass that could impede flow or system function.

Sampling techniques: When required, collect samples of oxygen in a sealed container by following cleanliness and purging procedures to avoid contamination of the sample.

\subsection{Disposal of Oxygen}

Per Title 40, Code of Federal Regulations, Parts 260 to 265, "Hazardous Waste Management," oxygen is not considered a hazardous waste. Uncontaminated liquid oxygen is best disposed of by allowing it to vaporize from a normal heat leak into the container and letting the vapor escape through the vent. Liquid oxygen may also be piped into an area free from combustible material and allowed to vaporize. 


\subsection{Protective Equipment}

Protective clothing and equipment shall be included in personnel protective measures.

Hand and foot protection: Gloves for work near cryogenic systems must be of good insulating quality. They should be designed for quick removal if liquid oxygen gets inside. Cryogenic gloves do not protect against immersion in liquid oxygen. They are limited to only providing insulation protection from temperature extremes. Because of the danger of a cryogenic splash, shoes should have high tops and pant legs should be worn outside and over the shoe tops. Leather shoes are recommended.

Head, face, and body protection: Personnel handling liquid oxygen shall wear splash protection. A face shield or a hood with a face shield shall be worn. If liquid oxygen is being handled in an open system, an apron of impermeable material should be worn.

Impermeable clothing: Oxygen can saturate clothing, rendering it extremely flammable. Clothing described as flame resistant or flame retardant in air may be flammable in an oxygen-enriched atmosphere. Impermeable clothing with good insulating properties is effective in protecting the wearer from burns due to cryogenic splashes or spills, but even these components can absorb oxygen.

Oxygen vapors on clothing: Any clothing that has been splashed or soaked with oxygen vapors shall be removed and unused until it is completely free of oxygen vapors.

Exposure to oxygen-rich atmospheres: Personnel exposed to high-oxygen atmospheres should leave the area and avoid all sources of ignition for at least 20 minutes, until the oxygen in their clothing dissipates. Removal of clothing should be considered.

Respiratory protection: Respiratory protection is not usually required in oxygen operations.

Storage of protective equipment: Facilities should be available near the oxygen use or storage area for the proper storage, repair, and decontamination of protective clothing and equipment. Safety and protective equipment shall be periodically inspected to ensure it is maintained in reliable condition at all times during use.

\subsection{Smoking Regulations}

- Smoking and open flames are prohibited within a minimum of 50 feet of an oxygen system.

- Persons who have been in an oxygen-enriched environment shall not smoke until they have been in a safe area for at least 20 minutes. Clothing saturated with oxygen vapor can be extremely hazardous.

\subsection{Vapor Detection}

High-oxygen-concentration detectors are not normally required. 


\section{OXYGEN HANDLING AND STORAGE}

This section is based on NASA Safety Manual [2] and provides common-sense type summary of oxygen handling.

\subsection{Oxygen Handling}

All gauges, valves, regulators, piping, and equipment to be used in oxygen service must be cleaned for oxygen service. Never use an oxygen jet as compressed air for cleaning purposes, especially for cleaning clothing, as it increases the likelihood of an engulfing fire. Protect cylinders from physical damage; do not drag, roll, slide, or drop. Instead, use a cart (trolley, hand truck, etc.) designed to transport cylinders. Do not allow storage area temperature to exceed $50^{\circ} \mathrm{C}\left(122^{\circ} \mathrm{F}\right)$. Read the product label before using the product and determine its properties and related hazards before using it. Do not remove or deface labels provided by the supplier for the identification of the cylinder contents. Leave valve protection caps in place until the container has been secured against either a wall or bench or placed in a container stand and is ready for use. Use an adjustable strap wrench to remove over-tight or rusted caps. Before connecting the container to the system, check the system suitability for pressure rating and material compatibility, and also ensure that there is no back flow from the system into the container. Test the oxygen system for leaks before use. Employ suitable pressure-regulating devices on all containers when oxygen gas is being released into a system with lower pressure rating than that of the container. Never insert an undesirable object (e.g., wrench, screwdriver, pry bar, etc.) into valve cap openings. Doing so may damage the valve, causing a leak to occur. Close container valves after each use and when empty, even if is still connected to the system. Never attempt to repair or modify container valves or safety relief devices. Damaged valves should be reported immediately to the supplier for replacement. Do not use containers for any purpose (as rollers or supports), other than to contain the gas as supplied. Never strike an arc on a compressed gas cylinder or make a cylinder a part of an electrical circuit. Do not smoke while handling product or cylinders. Never re-compress a gas or a gas mixture without first consulting the supplier. Never attempt to transfer gases from one cylinder/container to another. Always use a backflow protective device in piping. When returning cylinder, install valve outlet cap or plug leak tight. Never permit oil, grease, or other readily combustible substances to come into contact with valves or containers containing oxygen or other oxidants. Do not use rapidly opening valves (e.g. ball valves). Open valve slowly to avoid pressure shock. Never pressurize the entire system at once. Use only with equipment cleaned for oxygen service and rated for cylinder pressure. Never use direct flame or electrical heating devices to raise the pressure of a container. Containers should not be subjected to temperatures above $50^{\circ} \mathrm{C}\left(122^{\circ} \mathrm{F}\right)$. Prolonged periods of cold temperature below $-30^{\circ} \mathrm{C}\left(-20^{\circ} \mathrm{F}\right)$ should be also avoided.

\subsection{Oxygen Storage}

Cylinders should be separated from any source of flame or any object that can combust by a minimum distance of 20 feet or by a barricade of noncombustible material at least 5 feet high, having a fire resistance rating of at least $1 / 2$ hour. Containers should be stored in an area that is well ventilated, preferably in the open air. Full containers should be stored so that oldest stock is used first. Stored containers should be periodically checked for general condition and leakage. Observe all regulations and local requirements regarding storage of containers. Protect containers stored in the open against rusting and extreme weather conditions. Containers should not be stored in conditions likely to encourage corrosion. Containers should be stored in the vertical position and properly secured to prevent toppling. The container should have tightly closed valves with caps or plugs. Suitable protection shall be provided between oxygen storage containers and incompatible materials, plant equipment, buildings, test areas, and property lines so that any accidental or hazardous event has a minimum effect on the personnel and public safety. This protection may include separation by distance and by protective structures such as barricades 
or cell enclosures. Planning for protection and safety of personnel and equipment must start at the initial facility design stages.

\subsection{Quantity-Distance Guidelines for Gaseous Oxygen Storage}

Quantity-distances for bulk gaseous oxygen storage facilities are intended to provide facility protection from external fire exposure. A bulk oxygen system is an assembly of equipment, such as oxygen storage containers, pressure regulators, safety devices, vaporizers, manifolds, and interconnecting piping, that has a storage capacity of more than $20,000 \mathrm{ft}^{3}\left(566 \mathrm{~m}^{3}\right)$ of oxygen, including unconnected reserves at the site. The bulk oxygen system terminates at the point where oxygen at service pressure first enters the supply line. The oxygen containers may be stationary or movable.

Bulk oxygen storage systems shall be located either above ground and outdoors or shall be installed in a building of fire-resistant construction that is adequately vented and is used exclusively for storing oxygen.

Containers and associated equipment should not be located beneath, or exposed to, the failure of electric power lines or piping containing any flammable liquid or gas.

\subsection{Site and Equipment Design and Practice}

Structures: The storage facility (including support structures, roadways, drainage, etc.) should be made of fire-resistant materials and should be well ventilated. Normally, because of their special insulation, liquid oxygen storage tanks are not covered. If a storage facility requires protection, any open shed structure of fire-resistant materials may be used.

Ventilation: Areas in which liquid oxygen is handled must always be well ventilated to prevent excessive concentration of the gas. The liquid must never be disposed of in confined areas or in places that others may enter. Gaseous oxygen will increase the intensity of any fire.

Grounding and lightning protection: Buildings, storage systems, and transfer facilities shall be properly grounded against static electricity and should have approved lightning protection.

Housekeeping: Surrounding areas shall be kept free of grease, oil, oily waste, and all other organic materials (including vegetation). Smoking, sparks, and open flames are not permitted in storage areas.

Hazard warning: The bulk oxygen storage location shall be permanently placarded "OXYGEN - NO SMOKING - NO OPEN FLAMES.”

\subsection{Electrical Wiring and Equipment}

Oxygen storage and test installations are not classified as hazardous locations as defined and covered in Article 500 of NFPA 70, "National Electrical Code." Therefore, general purpose or weatherproof types of electrical wiring and equipment are acceptable, depending on whether the installation is indoor or outdoor. Such equipment shall be installed in accordance with the applicable provisions of NFPA 70.

Instrumentation and signal conditioner circuitry installed in oxygen systems should be designed to minimize the overheating and arcing that might result from a sensor system short. Materials should be chosen to minimize the chance of ignition should a short occur. In situations where arcing can occur, testing should verify that the maximum possible spark energy is insufficient to cause ignition of adjacent materials [7]. 


\section{SYSTEM DESIGN}

This section is based on Reference [2]. Safe use of oxygen requires the control of potential ignition energy mechanisms within oxygen systems by judiciously selecting system designs, "Standard Guide for Designing Systems for Oxygen Service" [14].

\subsection{Safety Approval Policy}

Before oxygen facilities, equipment, and systems are constructed, fabricated, and installed, the design shall be approved by the appropriate Safety Committee. The safety of systems for oxygen storage, handling, and use is enhanced when the facility plans, equipment designs, materials, and cleaning specifications are reviewed prior to construction.

\subsection{Oxygen Design Supplements}

Proven practical guidelines have been developed for the safe, successful design and use of oxygen gas. The following publications are valuable supplements to this chapter.

Mandatory: The "Standard Guide for Designing Systems for Oxygen," [14] is an essential part of oxygen system design principles. This standard is adopted as part of this chapter on oxygen safety. The designer/user is urged to obtain the latest revision of ASTM G88 [14]. The guide addresses system factors by which ignition and fire can be avoided. It is also required to refer to ASTM MNL 36 [1] for further indepth guidelines.

Recommendations: The publication, "Design Guide for High Pressure Oxygen Systems" [7], documents the critical and important detailed design data and provides a repository for such information, along with significant data on oxygen reactivity phenomena with metallic and nonmetallic materials in moderate to very high-pressure environments.

"Industrial Practices for Gaseous Oxygen Transmission and Distribution Piping System," Compressed Gas Association, CGA Pamphlet G4.4 [15].

\subsection{Component Design}

The designer is cautioned that, in addition to the standard analyses relating to component or system function, certain additional special analyses are recommended for the proper design of oxygen systems and must be considered in the design process. These analyses are listed by Bond et al. [7].

\subsection{General System Considerations}

The designer shall perform those standard analyses related to system flow capacity, dynamic and static structural loads, thermally induced loads, heat transfer, and so forth. These routine analyses are not unique to high-pressure oxygen systems, but inadequate attention to them can result in system failures magnified by the extreme reactivity of oxygen.

The use of high-pressure oxygen requires certain design considerations that need special attention at the system level. The architecture, flow dynamics, thermal design, and cleanliness of the system are important. Differences between cryogenic-liquid, super-critical, and gaseous oxygen systems must be considered. Details are provided in Chapter 5 of "Design Guide for High Pressure Oxygen Systems" by Bond et al. [7]. 


\subsection{System Flow Velocity}

The primary source of concern under high velocity oxygen flow conditions is the entrainment of particulates and their subsequent impingement on a surface, such as at a pipe bend. The result can be system ignition. The following flow dynamics design practices are recommended to avoid oxygen system fires $[7,11,13]$ :

- If practical, avoid velocities that are nominally above $100 \mathrm{ft} / \mathrm{s}$ in gaseous oxygen and avoid cavitation in liquid oxygen. Where this is impractical, use the alternate materials recommended in the references called out in Section 4 or those listed under the "High Pressure" column of Table 2 of this Section.

- If possible, avoid the use of nonmetals at locations within a system where sonic flow or cavitation can occur.

- Maintain fluid system cleanliness and limit entrained particulates as specified in Section 8.

\subsection{System Thermal Design}

System thermal design considerations shall include thermal characteristics at startup, and avoiding the lockup of cryogenic oxygen in a system segment. It is necessary to bring components to thermal equilibrium before starting up cryogenic oxygen turbo pump systems and to avoid hazardous component thermal transients which may affect clearances, cause rotor dynamic instabilities, or lead to high-speed friction. Any of these problems may result in ignition. Provision shall be made to provide thermal conditioning of the cryogenic system and components by gradually bleeding through cryogenic gas, then liquid. Cryogenic oxygen locked up between two valves or flow control components can absorb heat and, through the increase of pressure, cause structural failure. The system and components shall be designed to provide appropriate pressure relief. 


\section{SYSTEM CLEANLINESS}

Safe use of oxygen requires the control of potential ignition energy mechanisms within oxygen systems by maintaining scrupulously clean systems. Cleanliness (contamination control) is critical in oxygen components and systems. Contamination can cause ignition of components or systems of both metallic and nonmetallic materials by a variety of mechanisms, such as particle, mechanical, or pneumatic impact.

Designing for cleanliness is extremely important in oxygen systems. Metallic and nonmetallic contaminants and nonvolatile residues may have been left in components and systems after fabrication and assembly. Filters may need to be located throughout a system to control particulate contamination. Appropriate system flush and purge ports should be designed in the system at appropriate high and low points to allow effective flush or purge of the system.

\subsection{General Policy}

Before being placed in service, liquid and gaseous oxygen systems and components shall be completely cleaned. Since oxygen systems and components shall be periodically inspected to ensure that safety and component integrity are maintained during the life of the system, there are more opportunities for contamination. If the oxygen system contains components with a history of in-service failures, appropriate traps or components shall be removed, inspected, and periodically replaced. Effective cleaning will:

- Remove particles, films, greases, oils, and other unwanted matter. All component parts shall be free of burrs, chips, scale, slag, or foreign matter and shall be cleaned prior to assembly.

- Prevent loose scale, rust, dirt, mill scale, weld spatter, and weld flux deposited on moving and stationary parts from interfering with the component function and clogging flow passages.

- Reduce the concentration of finely divided contaminants, which are more easily ignited than bulk material.

\subsection{Oxygen Cleanliness References}

The following publications contain proven, practical guidelines that were developed to safely and successfully control contamination in oxygen systems.

Mandatory: ASTM G93-88, "Standard Practice for Cleaning Methods for Materials and Equipment Used in Oxygen-Enriched Environments," [16] is an essential part of this oxygen system cleanliness directive.

Recommendations: The following are highly recommended sources of information for oxygen system cleanliness:

- CGA Pamphlet G-4.1, "Cleaning Equipment for Oxygen Service” [17].

- $\quad$ Bond et al. [7], Chapters 6 to 8 .

- ASRDI Oxygen Technology Survey, Volume 2, "Cleaning Requirements, Procedures, and Verification Techniques" [18].

- "Cleanliness of Components for Use in Oxygen, Fuel, and Pneumatic Systems," Manned Space Flight Center, MSFC Spec 164B, November 1994, (contains acceptable methods of cleaning pipe, tubing, and flexible hose). 
- "Specifications for Surface Cleanliness of Fluid Systems," Kennedy Space Center, KSC-C-123H, 1995.

\subsection{Cleaning Procedures}

Cleaning methods and subsequent inspections must produce the degree of cleanliness required for the safe operation of oxygen service equipment and the necessary purity required for experimental test operations. Cleaning a component or system for oxygen service involves the removal of combustible contaminants, including the surface residue from manufacturing, hot work, and assembly operations, as well as the removal of all cleaning agents. These cleaning agents and contaminants include solvents, acids, alkalis, water, moisture, corrosion products, non-compatible thread lubricants, filings, dirt, scale, slag, weld splatter, organic material (such as oil, grease, crayon, and paint), lint, and other foreign materials. Injurious contaminants can be removed by cleaning all parts and maintaining this condition during construction, by completely cleaning the system after construction, or by a combination of the two. The prevention of recontamination before final assembly, installation, and use is essential to safe oxygen system operation.

Responsibility: The organization performing the cleaning service shall have the responsibility of developing detailed cleaning procedures. The oxygen systems cleanliness acceptability shall be based only on the quality specifications of the cleaning end result and not on the cleaning procedures used.

Cleaning procedure safety: The organization performing the cleaning services shall have responsibility for all safety aspects of oxygen cleaning procedures.

Special considerations: Components that could be damaged during cleaning should be removed and cleaned separately. Cleaning or disassembly operations that might affect tolerances or impair calibration of precision components should be performed only under the supervision of personnel qualified in the handling, calibration, and assembly of the components. The cleaning procedures established for each system or component shall be compatible with the design configurations. Prior to use, establish the compatibility of cleaning agents with all construction materials, making sure that time or temperature constraints are not exceeded.

\subsection{Verification of Oxygen System Cleanliness}

A key element of the contaminant control safety plan is the final inspection and verification of system cleanliness by using an approved acceptance specification. Experience has shown that approximately onehalf of all parts cleaned fail on the initial sampling to meet either the particulate or the nonvolatile residue specification. Should this occur, repeated cleaning is required until all parts pass both specifications [7].

Inspection procedures: Inspection shall be followed to verify cleanliness of components and systems for oxygen service.

Cleanliness acceptance criteria: Acceptance criteria for all systems and components are based on KSC-C-123H, "Surface Cleanliness of Fluid Systems" [19]. The acceptance level shall be 300-A. This represents a particle limit and a hydrocarbon limit identical to those which Kennedy Space Center [19] uses on ground equipment in oxygen service.

\subsection{Recommendations for Re-Inspection}

Oxygen components and systems shall be re-inspected periodically to ensure that safety and component integrity is maintained during the life of the system. Determination of system and component re-inspection intervals has proven to be a complex task. Detailed knowledge of construction materials, 
pressure levels, the use environment, and the service the system is performing must be applied. A record of re-inspections must be kept on file and labels placed on the inspected components. In establishing the re-inspection intervals, the following items should be considered:

- Routine disassembly and reassembly of oxygen piping systems invariably increases the level of contamination in the system because particulates are generated.

- Sampling of an assembled system for gas-borne contaminants yields only limited data on the internal cleanliness. This method of system sampling cannot be directly correlated with the cleanliness of internal system surfaces.

- The re-inspection plan must address the design service life of components.

- Additional insight regarding system contamination levels can be gained through systematic inspection of components (e.g., transducers, flexible hoses, relief valves, filters) removed for calibration, prooftesting, or periodic maintenance.

- Cleanliness levels in components and systems that have been in service shall be re-verified to make sure that the Cleanliness Acceptable Criteria are met.

- Reassembly procedures shall adhere to guidelines for original assembly, including assembly checkout.

Assembly of systems: After system and component disassembly and cleaning, reassembly of components and systems must be stringently controlled to ensure that the cleanliness criteria are met. All components requiring reassembly (e.g., valves, regulators, and filters) should be reassembled in a filteredair environment such as a clean room. Personnel should be properly attired in clean-room garments and gloves. All tools that contact component internal parts must be cleaned previously to the specified levels.

Final system checkout: After the system has been reassembled, a final pressure integrity and leak test should be performed with an appropriately filtered inert gas that has been analyzed for contaminants.

Hydrostatic tests: It is not recommended that hydrostatic tests be performed on cleaned systems, since this is likely to contaminate them. Conduct these tests on the components before cleaning and final assembly.

Cryogenic cold-shock: Cold-shocking a newly assembled liquid oxygen system by loading it with clean liquid nitrogen following final assembly is highly recommended. After the cryogenic cold-shock, the system should be emptied of liquid nitrogen and warmed to ambient temperature. Bolts and threaded connections must then be re-torqued to prescribed values, and gas leak-checking procedures should follow. The entire system should be inspected for evidence of cracking, distortion, or any other anomaly, with special attention directed to welds. Then system cleanliness must be checked and verified.

Final operational tests: Final operational tests should be run with oxygen (liquid or gas, as required by the system) at rated pressure. If it is possible to substitute nitrogen for this test, this should be done for greater safety in the operational test. Only verified clean, dry nitrogen shall be used for these tests. It is prudent to recheck the system filters for cleanliness after the test is completed. It is a good practice to perform the first oxygen pressurization of a system by remote control, since assembly-generated contaminants can cause ignition. 


\section{EMERGENCY PROCEDURES}

\subsection{Emergency Action}

In case of an emergency, institutional procedures should be followed. As a generic understanding of the emergency procedures, the following actions shall be followed [2]:

- Direct all personnel to evacuate the suspected hazardous area. Activate building evacuation alarms.

- Call the Emergency Dispatcher by dialing 911 or other designated emergency phone number.

- Isolate or shut off all oxygen supply sources.

- Attempt to control the emergency with the installed facility system safety equipment and preplanned procedures.

\subsection{Oxygen Leaks and Spills}

The quantity of oxygen that might leak from a system may range from extremely low up to an emergency situation. Leaks can occur from O-rings connections, the valve packing, or from the oxygen supply tubes used. There are three main types of leaks.

- Non-detectable leaks - This type of leak is normally not detectable (no hissing sound). These leaks may be the result of a failure in the O-ring or other connections.

- Slow leak (detectable by sound) - Slow leaks are detectable by sound. This quantity of oxygen being released poses minimal hazard to the workers. However, when detected, immediate emergency action is needed.

- Catastrophic leakage (broken valve or coupling) - Should massive quantities of oxygen be released, the enriched atmosphere of oxygen can greatly enhance a fire. If this event occurs, immediately call emergency services for appropriate action.

A general fire hazard for the nearby equipment always exists when a major oxygen leak occurs. However, with proper system design, material selection, operating procedures, and adequate ventilation, the hazard can be minimized. Oxygen vapor cloud may persist for a considerable distance downwind of a large liquid oxygen spill.

\subsection{Rescue}

Only personnel trained in specific emergency procedure shall engage in rescue activities. All other personnel shall stay clear of an emergency area. Rescue personnel should deluge a burning victim with water and move him/her to fresh air as soon as possible. Fire blankets should not cover a person saturated with oxygen, as it will prevent oxygen from dissipating from the clothing. Blankets can also become oxygen saturated, thus becoming a fire hazard.

\subsection{Firefighting/Fire Control}

Only personnel trained in specific firefighting techniques should engage in the firefighting. All other personnel should stay clear of the area. The following general recommendations are to be used as a guide for controlling fire. 
Liquid oxygen and fuel: When the fire involves liquid oxygen and liquid fuels, control it as follows:

- If fuel and liquid oxygen are mixed but not burning, quickly evacuate personnel, isolate the area from sources of ignition, and allow the oxygen to evaporate. Mixtures of fuel and liquid oxygen present an extreme explosion hazard.

- If a liquid oxygen/fuel fire occurs, shut off fuel and oxygen supplies. Only water sprays or fog should be used to cool the fire. Foams should not be applied. The foam will retard oxygen evaporation and will not extinguish the fire.

\subsection{Transportation Emergencies}

Hazards caused by damage to oxygen transportation systems (road, rail, air, and water) include spills and leaks. Such spills may result in fires and explosions. However, such situations are not applicable to INL laboratory experiments.

\subsection{Decontamination of Oxygen and Fuel Mixtures Liquid}

If there is an oxygen spill/leak, in due course of time, oxygen will eventually evaporate from contaminated surfaces. When liquid oxygen has been contaminated by fuel, isolate the area from sources of ignition and quickly evacuate personnel. Allow the oxygen to evaporate and the residual fuel to reach ambient temperatures. Purge the oxygen system with gaseous nitrogen prior to any other cleanup step.

\subsection{First Aid}

Dial 911 (or other emergency designated phone number). Contact with liquid oxygen or its cold boiloff vapors can produce cryogenic burns (frostbite). Therefore, unprotected parts of the body should not be allowed to contact non-insulated pipes or vessels containing cryogenic fluids. The cold metal will cause the flesh to stick and tear. Treatment of truly frozen tissue requires professional medical supervision since incorrect first aid practices almost always aggravate the injury. 


\section{PROPERTIES OF OXYGEN}

\subsection{Physical Properties}

Oxygen is an element which, at atmospheric temperatures and pressures, exists as a colorless, odorless, and tasteless gas. High purity liquid oxygen is a light blue, transparent liquid. It is an extremely cold cryogenic fluid, which makes handling it potentially hazardous. It boils at $-297^{\circ} \mathrm{F}\left(90^{\circ} \mathrm{K}\right)$ at atmospheric pressure. It boils vigorously in ambient conditions. Table 3 provides more information on the physical properties of oxygen.

\subsection{Chemical Properties}

Solubility: Most common solvents are solid at liquid oxygen temperatures. Liquid oxygen is completely miscible with liquid nitrogen and liquid methane. Light hydrocarbons are usually soluble in liquid oxygen and such mixtures are very hazardous.

Reactivity: In either gaseous or liquid form, oxygen is a strong oxidizer that vigorously supports combustion.

A material's rate of reaction with oxygen depends on the conditions of its exposure to oxygen and its physical and chemical properties. A particular material may react with oxygen.

Table 3. Selected Safety-Relevant Physical Properties of Gaseous and Liquid Oxygen [21, 1].

\begin{tabular}{|c|c|c|c|}
\hline \multicolumn{4}{|l|}{ Gaseous Oxygen } \\
\hline \multicolumn{2}{|l|}{ Reference temperature } & $68^{\circ} \mathrm{F}$, & $(293.15 \mathrm{~K})$ \\
\hline \multicolumn{2}{|l|}{ Standard pressure $(1 \mathrm{~atm})$} & 14.69 psia, & $(101.325 \mathrm{kPa})$ \\
\hline \multicolumn{2}{|l|}{ Density } & $0.0831 \mathrm{lb} / \mathrm{ft}^{3}$ & $\left(1.33 \mathrm{~kg} / \mathrm{m}^{3}\right)$ \\
\hline \multicolumn{2}{|l|}{ Specific volume } & $12.03 \mathrm{ft}^{3} / \mathrm{lb}$ & $\left(0.751 \mathrm{~m}^{3} / \mathrm{kg}\right)$ \\
\hline \multicolumn{2}{|l|}{ Specific heat at constant pressure, $C_{\mathrm{p}}$} & $0.220 \mathrm{Btu} /(\mathrm{lb} \cdot \mathrm{F})$ & $(0.919 \mathrm{~J} / \mathrm{g} \cdot \mathrm{C})$ \\
\hline \multicolumn{2}{|l|}{ Specific heat at constant volume, $\mathrm{C}_{\mathrm{v}}$} & $0.157 \mathrm{Btu} /(\mathrm{lb} \cdot \mathrm{F})$ & $(0.68919 \mathrm{~J} / \mathrm{g} \cdot \mathrm{C})$ \\
\hline \multicolumn{2}{|l|}{ Velocity of sound } & $1070 \mathrm{ft} / \mathrm{s}$ & $(326 \mathrm{~m} / \mathrm{s})$ \\
\hline \multicolumn{2}{|l|}{ Critical density } & $27.2 \mathrm{lb} / \mathrm{ft}^{3}$ & $\left(436.1 \mathrm{~kg} / \mathrm{m}^{3}\right)$ \\
\hline \multicolumn{2}{|l|}{ Critical pressure } & 731.4 psia, & $(5043 \mathrm{kPa})$ \\
\hline \multicolumn{2}{|l|}{ Critical temperature, } & $-181.43^{\circ} \mathrm{F}$ & $(154.6 \mathrm{~K})$ \\
\hline \multicolumn{4}{|l|}{ Liquid Oxygen } \\
\hline \multirow{7}{*}{ Vapor pressure at selected temperatures } & $268.6 \mathrm{R}$ & 588 psia & $(4052.0 \mathrm{kPa})$ \\
\hline & $259 \mathrm{R}$ & 441 psia & $(3039.0 \mathrm{kPa})$ \\
\hline & $240 \mathrm{R}$ & 294 psia & $(2026.5 \mathrm{kPa})$ \\
\hline & $216 \mathrm{R}$ & 147 psia & $(1013.2 \mathrm{kPa})$ \\
\hline & $196 \mathrm{R}$ & 73.5 psia & $(506.60 \mathrm{kPa})$ \\
\hline & $195 \mathrm{R}$ & 29.4 psia & $(202.64 \mathrm{kPa})$ \\
\hline & $162 \mathrm{R}$ & $14.7 \mathrm{psia}$ & $(101.32 \mathrm{kPa})$ \\
\hline \multicolumn{2}{|l|}{ Boiling point at $1 \mathrm{~atm}}$, & $-297.3^{\circ} \mathrm{F}$ & $(90.18 \mathrm{~K})$ \\
\hline \multicolumn{2}{|l|}{ Density } & $71.23 \mathrm{lb} / \mathrm{ft}^{3}$ & $\left(1141 \mathrm{~kg} / \mathrm{m}^{3}\right)$ \\
\hline \multicolumn{2}{|l|}{ Specific heat at constant pressure, $C_{p}$} & $0.221 \mathrm{Btu} /(\mathrm{lb} \cdot \mathrm{F})$ & $(0.93 \mathrm{~J} / \mathrm{g} \cdot \mathrm{C})$ \\
\hline \multicolumn{2}{|l|}{ Specific heat at constant volume, $C_{v}$} & $0.284 \mathrm{Btu} /(\mathrm{lb} \cdot \mathrm{F})$ & $(1.16 \mathrm{~J} / \mathrm{g} \cdot \mathrm{C})$ \\
\hline \multicolumn{2}{|l|}{ Velocity of sound } & $2963 \mathrm{ft} / \mathrm{s}$ & $(90.3 \mathrm{~m} / \mathrm{s})$ \\
\hline \multicolumn{2}{|l|}{ Heat of vaporization } & $91.59 \mathrm{Btu} / \mathrm{lb}$ & $(213 \mathrm{~J} / \mathrm{g})$ \\
\hline \multicolumn{2}{|l|}{ Heat of fusion at triple point } & $5.98 \mathrm{Btu} / \mathrm{lb}$ & $(13.9 \mathrm{~J} / \mathrm{g})$ \\
\hline \multicolumn{2}{|l|}{ Triple point temperature } & $-361.8^{\circ} \mathrm{F}$ & $(54.35 \mathrm{~K})$ \\
\hline \multicolumn{2}{|l|}{ Triple point pressure } & $0.022 \mathrm{psia}$ & $(0.152 \mathrm{kPa})$ \\
\hline
\end{tabular}




\section{SAFETY COMPLIANCE ACTIVITIES AND A PAST ACCIDENT}

INL has either completed or initiated activities related to safe handling of oxygen systems. Some of these are described below.

\subsection{Oxygen Monitors}

INL has completed a study (attached in Appendix A) to assess the need for monitors for the presence of combustible and toxic (oxygen) gas in the laboratory. This study discusses the type of monitors to be installed, locations where these should be installed, and the kind of data that can be expected from these monitors. At present, a suitable number of oxygen sensors have been installed in the laboratory.

\subsection{Laboratory Hazard Review}

Before performing any experiments in the laboratory, the INL Safety Committee conducts a Laboratory Instruction (LI) Review of the hydrogen/oxygen generating system in a laboratory designated as "REC 670-BCTC Bay 9." The Safety Committee examines the experimental process, health and safety issues related to the experimental procedure, and the instrumentation available to conduct the experiment and monitor any hazards. The Safety Committee examined a document (attached in Appendix B) and has granted permission to proceed with the experiment. In view of the extensive material contained in the present report, a few more reviews may be performed if required by the experimental conditions. The exact determination will be made soon.

\subsection{Canadian AEC Chalk River Accident Report}

The INL has collaborated with Atomic Energy of Canada, Chalk River and has exchanged information periodically on hydrogen generation. As a result of this interaction and also as a part of information review on oxygen handling, INL obtained a report on an accident [21]. The following is a summary of that accident and investigative report, which can provide useful information for future safe handling of oxygen.

An accident occurred on May 4, 2006, in Room 241 of Building 250 at the Atomic Energy of Canada Chalk River Facility [21]. The incident occurred on a newly fabricated gas distribution panel for a recombiner test rig. The operator indicated that he/she had opened the cylinder valves on the gas supply manifold at about $8 \mathrm{AM}$ ( $\sim 5.5$ hours before the incident). The operator further indicated that the pressure on supply manifold pressure gauges (PI-35 and PI-36) read approximately $2300 \mathrm{psig}$. At 1:25 PM, he/she opened isolation valve (V-104) to pressure regulator (PCV-23) in Room 241 without incident. The operator then opened isolation valve (V-105) to pressure regulator (PCV-16) in Room 241) and fire immediately erupted from the pressure gauges attached to PCV-16. The operator indicated that he/she heard a "pop" or "tap" and then saw two 3 to 4 foot flames erupt in a "V" pattern from the gauges while he/she exited the room. The operator indicated that he/she rushed downstairs to the supply manifold and shut all oxygen supply valves, then all nitrogen and hydrogen supply valves to Room 241 . The operator believes the gauge cover from one of the pressure gauges impacted his/her arm as it was ejected from the gauge. This incident was investigated by Wendell Hill \& Associates and following conclusions were drawn [21].

The regulator PCV-23 was not damaged internally during the incident even though it was pressurized with oxygen immediately prior to PCV-16 and was closely positioned to PCV-16. However, PCV-23 exhibited a large amount of white grease-like residue in all ports (Figures 4 and 5), including the inlet/outlet ports and the gauge ports. Visual examination of this residue also revealed a brown, greaselike, substance within the whitish residue. The residue samples were analyzed to determine that this 
material contained PTFE (Teflon). PTFE is widely considered oxygen compatible, but also contained both polyethylene and polyester based compounds, which are considered to exhibit poor compatibility with oxygen. It was determined that a Loctite sealant with Teflon and a Loctite primer were used during the installation.

Autogenous Ignition Temperature (AIT) in high pressure oxygen. The AIT of the Loctite primer and the sealant were determined to be $\sim 163^{\circ} \mathrm{C}$ and $\sim 193^{\circ} \mathrm{C}$, respectively. By comparison, PTFE materials generally have AIT in the range 434 to $450^{\circ} \mathrm{C}$. These data, shown in Table 4, provide a means of evaluating whether a material is capable of promoting other flammable materials during an oxygen fire.

Table 4. Non-metal oxygen compatibility data.

\begin{tabular}{|l|c|c|c|}
\hline \multicolumn{1}{|c|}{ Non-Metal } & $\begin{array}{c}\text { Auto Ignition Temp. } \\
(\mathrm{AIT}),{ }^{\circ} \mathrm{C}\end{array}$ & $\begin{array}{c}\text { Heat of Combustion } \\
\left(\Delta \mathrm{H}_{\mathrm{c}}\right) \mathrm{Ca} / \mathrm{gm}\end{array}$ & $\begin{array}{c}\text { Oxygen Index } \\
(\mathrm{OI})\end{array}$ \\
\hline Loctite Primer 7649 & 163 & 6,280 & -- \\
\hline Loctite Sealer 567 & 194 & 6,643 & $23.9-36$ \\
\hline Nylon 6/6 & $178-270$ & $7,400-7,900$ & 22 \\
\hline Buna-N (Nitrile rubber) & 173 & 8,500 & 17.5 \\
\hline Polyethelene (PE) & $176-220$ & 11,150 & $32-38$ \\
\hline Propylene (generic) & 174 & 11,000 & $21-32$ \\
\hline PVC & 239 & 4,990 & 27.4 \\
\hline Silicone Rubber & 275 & 3,600 & $56-100$ \\
\hline Polycarbonate (generic) & 310 & $7,600-9,400$ & $95-100$ \\
\hline Viton (FKM) & $300-325$ & $3,000-5,000$ & \\
\hline Teflon (PTFE) & $427+$ & $1,000-1,700$ & \\
\hline
\end{tabular}

The data in Table 4 show that different materials exhibit vastly different oxygen compatibility. The oxygen compatibility for materials is defined by ASTM standards to be the "ability of a substance to coexist with both oxygen and a potential source(s) of ignition at an expected pressure and temperature with a magnitude of risk acceptable to the user." Generally, preferred nonmetals have a high auto-ignition temperature, AIT (i.e., they resist ignition until higher temperatures), low heat of combustion, $\Delta \mathrm{H}_{\mathrm{c}}$ (i.e., they have low damage potential), and high oxygen indices, OI (i.e., a high concentration of oxygen is required before they become flammable at ambient pressure). The most oxygen compatible elastomer and plastic for oxygen applications are considered to be Viton and Teflon, respectively based on their AIT, $\Delta \mathrm{H}_{\mathrm{c}}$, and $\mathrm{OI}$ values.

PCV-16, (Figure 5) the fire-damaged regulator, was examined to trace the internal melt/flow patterns. Previous experience indicates that "fire follows flow" for components and materials consistent with the Chalk River installation. Thus, the internal burn patterns provide evidence pertaining to the origin site and kindling chain associated with the incident. The burn patterns associated with PCV-16 indicated that extensive burning developed from the extreme inlet to the regulator, at the inlet port to the extreme outlet of the regulator (Figure 5). The inlet screen filter was estimated to be approximately $80 \%$ consumed. The high-pressure regulating valve assembly spring, poppet, and seat retainer were completely consumed. The outlet port was heavily damaged by fire and a significant degree of consumption of the brass body was observed at the outlet port. Since brass is generally nonflammable under the service conditions of the Chalk River incident, the burning at the outlet was consistent with a concentration of burning from other flammable materials swept by the flow toward the downstream valve. This containment of pressure and burning in the downstream port would be expected to greatly increase the combustion kinetics and 
establish conditions for a pressure blow-out. This highly energetic internal burning and pressure blowout is demonstrated by the extensive burning of the regulators outlet, the apparent consumption/damage of needle valve, V-62 (since it was never identified in the post-incident debris), and the damage observed on the T-junction downstream of V- 62 .

The combustion observed within PCV-16 was consistent with a kindling chain event that kindled materials inside the regulator from its inlet to its outlet. The most probable kindling chain was associated with burning of the grease-like (Loctite) residue that was observed in PCV-23 and also used during the assembly and installation of PCV-16. The testing indicated that it would have ignited at a relatively low temperature and delivered sufficient energy to kindle the stainless steel filter screen and valve assembly (spring, poppet, seat/retainer). Once these metallic elements ignited, then significant propagation and energy release would be expected and self-sustained combustion would have ensued. However, since the internal combustion patterns extended upstream of PCV-16, it was not considered consistent with the origin of the fire. Generally speaking, for high-pressure oxygen fires associated with the materials involved in this incident, the fire's origin is usually associated with the most upstream component/element that exhibits burning.

The Whitey valve (V-105) was a "ball valve", which includes an "interstage" (inside the ball element) that would have been at ambient pressure prior to it being rotated open. When the interstage of a ball valve pressurizes rapidly, adiabatic compression heating develops momentarily in the interstage while the flow rate establishes critical conditions at the downstream seat of the valve. This rapid pressurization of the interstage is an adiabatic compression event that delivers its energy in the interstage of the valve. Normally, the PTFE downstream seat of the valve would not be considered vulnerable to ignition by this mechanism since the thermal energy develops inside the ball's interstage (metallic element); however, if contamination were present in the interstage, then ignition would be considered likely. Since each of these three heat sources would occur simultaneously when the valve was being opened, and since the physical evidence indicates ignition at the upstream seat and interstage of the valve, the ignition mechanism(s) associated with the fire in question was probably a combination of those indicated above (i.e., mechanical friction, flow friction, and adiabatic compression in the valve's interstage). Evidence was observed of fire propagation completely through the regulator, PCV-16, and into the downstream tubing. The needle valve downstream, V-62, is understood to have never been recovered and was probably ejected under pressure while combustion intensified at the regulators downstream port. Based on the heavy grease-like residue observed in all ports of PCV-23, it is considered likely that this residue was present in PCV-16 and promoted from the ignition at V-105. Since this residue exhibited a very low auto-ignition temperature (AIT) consistent with hydrocarbon-based grease, its heat of combustion would be expected to kindle the stainless steel elements of the regulator. The burning of these metallic elements would have greatly intensified the overall energy release from the regulator. The intense burning of PCV-16 and the fire's propagation from inlet to outlet, including the pressure gauges, is considered to have been largely influenced by this Loctite sealant, which should be considered highly incompatible with oxygen. 


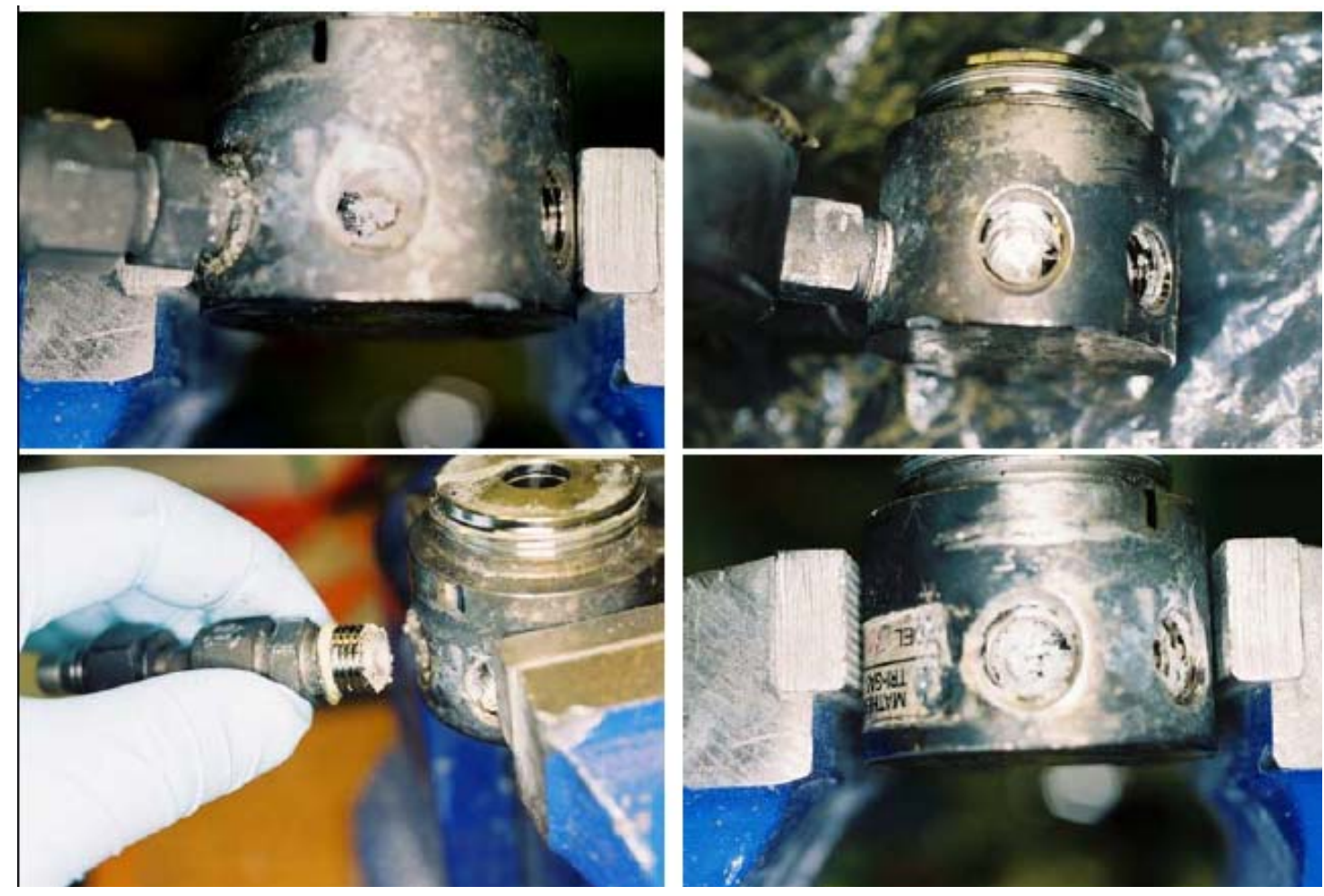

Figure 4. AEC's PCV-23, showing ports after the accident.
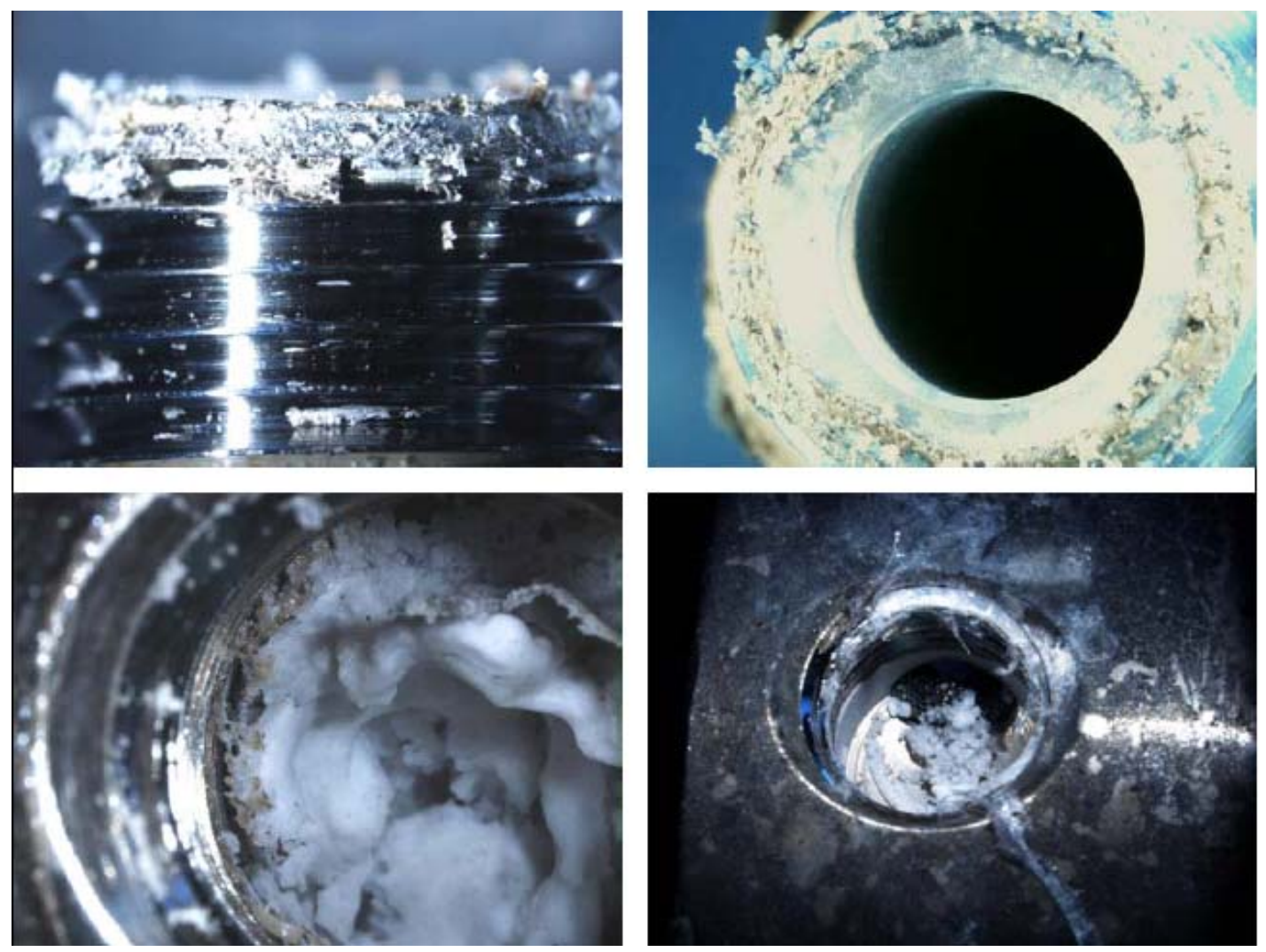

Figure 5. "White" contamination at the PCV-23 ports. 

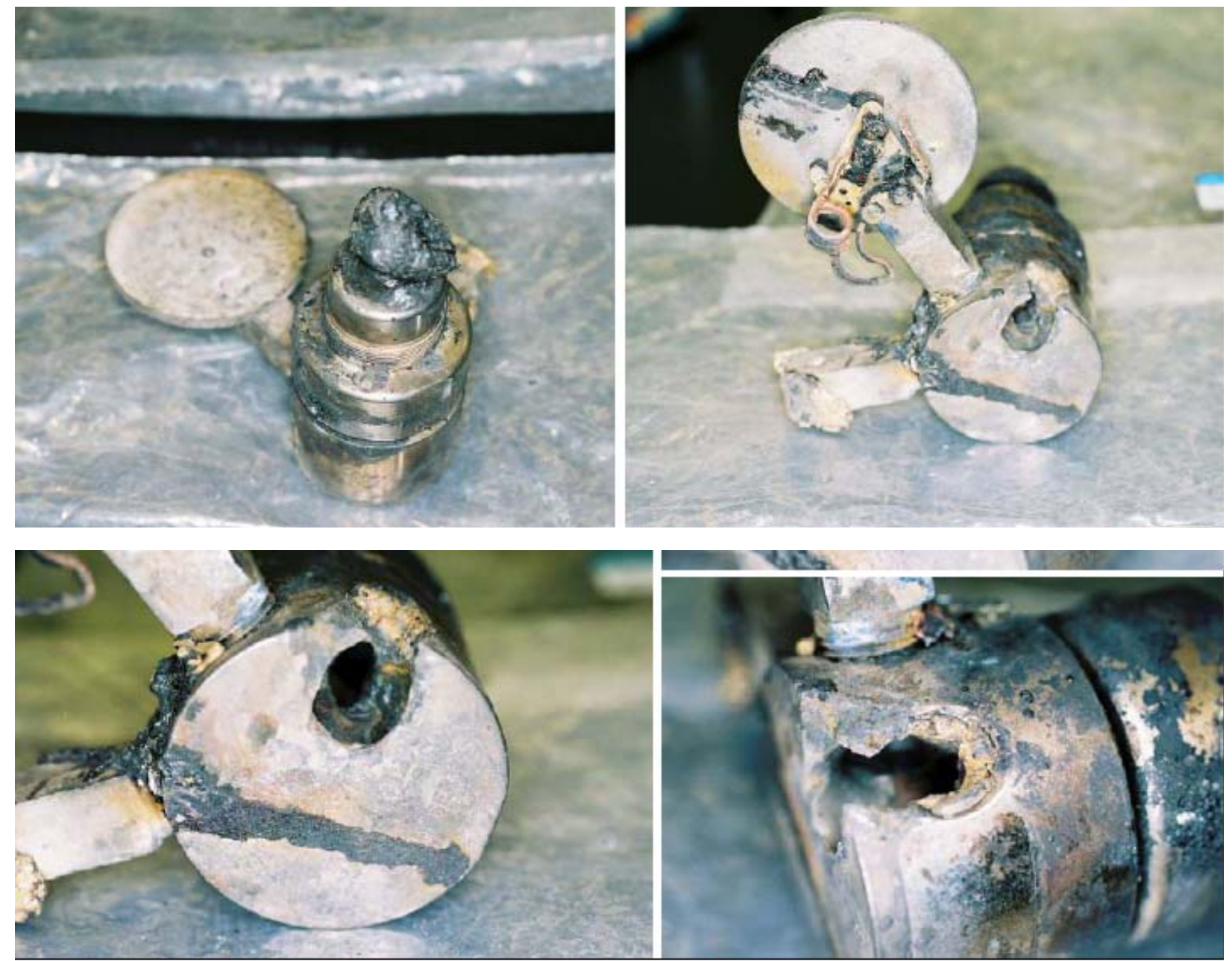

Figure 6. PCV-16 valve showing heavy combustion damage at the outlet port (shown lower). 

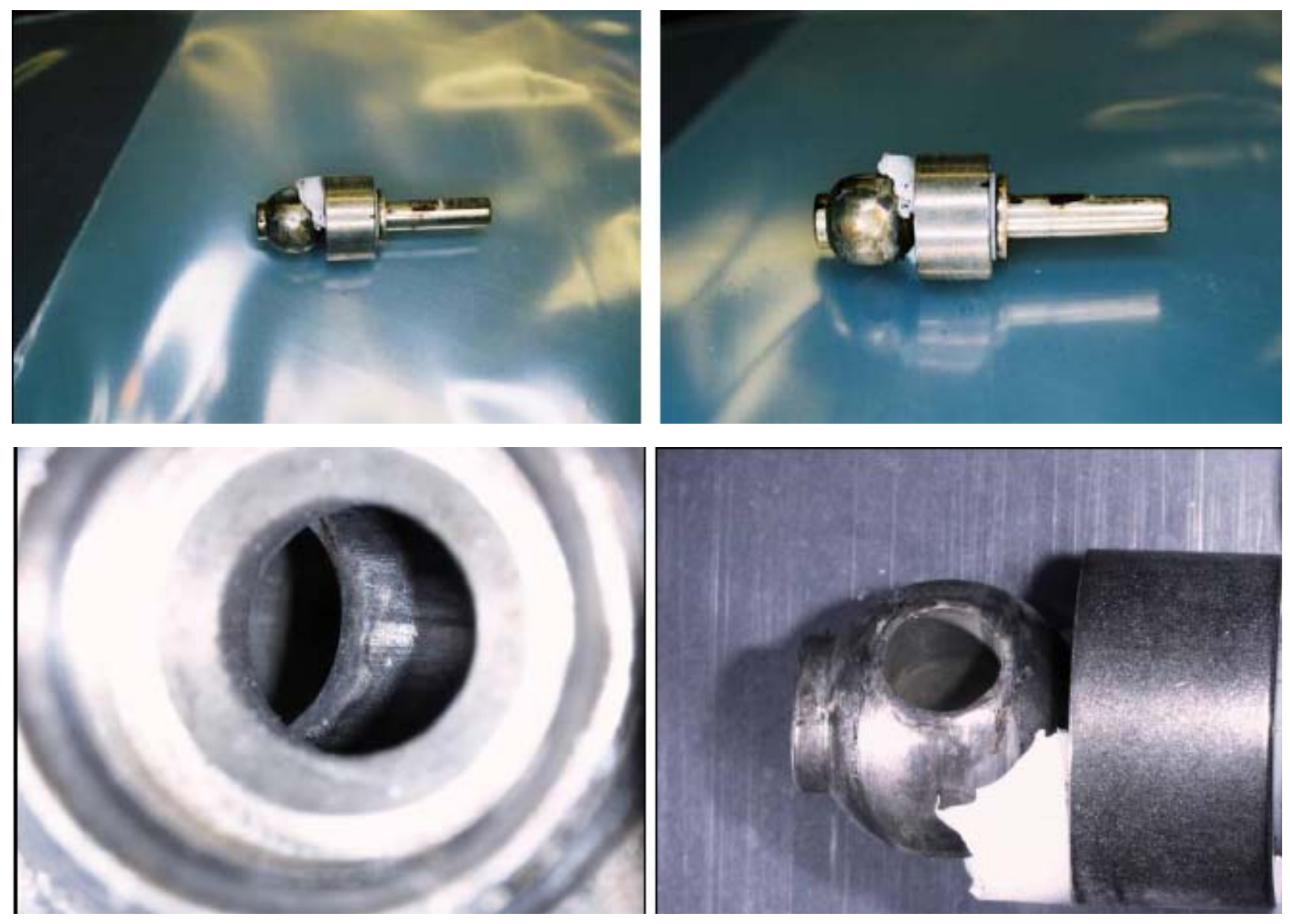

Figure 7. V-105 "ball" valve showing damage by fire. 


\section{REFERENCES}

1. H. D. Beeson, W. F. Stewart, and S. S. Woods (Editors), "Safe Use of Oxygen and Oxygen Systems: Guidelines for Oxygen System Design, Materials Selection, Operations, Storage, and Transportation," ASTM Report No. MNL-36, ASTM (American Society of Testing and Materials) International, West Conshohocken, PA, 2000.

2. “Glenn Safety Manual Chapter 5 - Oxygen BMS," NASA Glenn Research Center Document GRCM8300.001, February 2005.

3. M. C. Vidal Vázquez, "Binary Mixture Flammability Characteristics for Hazard Assessment," Ph. D. Thesis, Texas A\&M University, December 2005.

4. M. G. Zabetakis, "Flammability Characteristics of Combustible Gases and Vapors," Bureau of Mines, Bulletin 6271965.

5. M. S. Mannan (editor), "Lees' Loss Prevention in the Process Industries: Hazard Identification, Assessment \& Control, Vol. I-III,” Third Edition, Butterworth-Heinemann, Amsterdam, 2005.

6. "Guide to Fire Hazards Properties of Flammable Liquids, Gases, and Volatile Solids," NFPA 325, National Fire Protection Association, Quincy, MA, 1994.

7. A. C. Bond, et al., "Design Guide for High Pressure Oxygen Systems," NASA RP 1113, 1983.

8. "Fire Hazards in Oxygen Systems," ASTM Report No. G4.05, ASTM International, West Conshohocken, PA.

9. "Standard Guide for Evaluating Nonmetallic Materials for Oxygen Service," ASTM Report No.G63 92, ASTM International, West Conshohocken, PA.

10. "Recommended Practice on Materials, Equipment, and Systems Used in Oxygen-Enriched Atmospheres," NFPA 53, National Fire Protection Association, Quincy, MA, 1999.

11. H. W. Schmidt and D. E. Forney, "Oxygen Systems Engineering Review," ASRDI Oxygen Technology Survey, Vol. 9, NASA SP 3090, 1975.

12. "Standard Guide for Evaluating Metals for Oxygen Service," ASTM Report No.G94 90, ASTM International, West Conshohocken, PA

13. R. E. Williams, F. J. Benz, and K. McIlroy, "Ignition of Steel by Impact of Low-Velocity Iron/Inert Particles in Gaseous Oxygen," Flammability and Sensitivity of Materials in Oxygen Enriched Atmospheres: Third Volume, ASTM STP 986, ASTM International, West Conshohocken, PA, 1988.

14. "Standard Guide for Designing Systems for Oxygen," ASTM Report No. G88-90, 1991, ASTM International, West Conshohocken, PA.

15. "Industrial Practices for Gaseous Oxygen Transmission and Distribution Piping System," CGA Pamphlet G4.4, Compressed Gas Association, Arlington, VA, 1980.

16. "Standard Practice for Cleaning Methods for Materials and Equipment Used in Oxygen-Enriched Environments," ASTM Report No. G93-88, ASTM International, West Conshohocken, PA.

17. "Cleaning Equipment for Oxygen Service," CGA Pamphlet G-4.1, Compressed Gas Association, Arlington, VA.

18. H. Bankaitis and C. F. Schueller, "ASRDI Oxygen Technology Survey, Volume 2: Cleaning Requirements, Procedures, and Verification Techniques," NASA Report NASA SP-3072, 1972.

19. "Specifications for Surface Cleanliness of Fluid Systems," Kennedy Space Center, KSC-C-123H, 1995. 
20. H. M. Roder and L. A. Weber, "ASRDI Oxygen Technology Survey, Volume 1: Thermophysical Properties,” Report NASA-SP-3071, 1972.

21. B. Newton, "Investigation Report for Canadian Atomic Energy of Canada, May 4, 2006, Room 241 (Bldg 250) Chalk River Fire Incident," Wendell Hull Associates, Private Communication from Canadian AEC, April 2008.

22. "Oxygen Pipeline Systems," IGC Document 13/02/E, European Industrial Gas Association, Brussels, 2002. 
Appendix A

\section{Monitoring for Combustible and Toxic Gases}




\section{Appendix A}

\section{Monitoring for Combustible and Toxic Gases}

\section{Cadwallader, December 2006}

Some questions have arisen on what are the best, most safety conservative, practices for stationary, 'fixed point' gas monitors that would be used for sensing flammable, toxic, or oxygen-displacing gases, or elevated oxygen concentrations in room air. This EDF presents data on monitors and design practices to answer these questions. The EDF is divided into four parts: monitor selection for indoor applications, monitor setpoints, monitor placement in rooms, and a few system usage notes.

For clarity, the National Electrical Code (NFPA 70), which is adopted by the US DOE (DOE, 1998), in Article 500-7 (K) "Combustible Gas Detection System" states:

A combustible gas detection system shall be permitted as a means of protection in industrial establishments with restricted public access and where the conditions of maintenance and supervision ensure that only qualified persons service the installation. Gas detection equipment shall be listed for detection of the specific gas or vapor to be encountered. Where such a system is installed, equipment specified in $500.7(\mathrm{~K})(1),(\mathrm{K})(2)$, or $(\mathrm{K})(3)$ shall be permitted. The type of detection equipment, its listing, installation locations(s), alarm and shutdown criteria, and calibration frequency shall be documented when combustible gas detectors are used as a protection technique. NFPA 70 also recommends following ISA-RP12.13.02, Installation, Operation, and Maintenance of Combustible Gas Detection Instruments (ANSI, 2003).

The ISA-RP12.13.02 (ANSI, 2003), section 6.2.1, states:

A fixed gas detection system should be installed that is capable of monitoring those parts of a plant or other premises where flammable gas(es) accidentally accumulate and may create significant hazard. The system should be capable of giving an early audible or visual (or both) warning of both the presence and the general location of an accident accumulation of flammable gas(es), in order to initiate one or more of the following actions, either automatically or under manual control:

a) safe evacuation of premises

b) appropriate fire-fighting procedures

c) shutdown of process or plant

d) ventilation control

\section{Monitor Selection.}

The initial step in monitor selection is to define the gases to be sensed. This includes listing all gases to be used in the room or facility: process gases, maintenance or cleaning gases, welding gases, background gases, and product gases. Table 1 gives some basic data on a number of gases - the list of gases found in the lab or facility should be completed to this level of detail. With the gases defined, then the type of monitor to sense those gases can be selected. Chou (2000) has reviewed all of the major types of gas monitors, including their operating temperature ranges, response times, accuracies, repeatabilities, drift in settings, and life expectancies. Table 2 below gives some highlights from Chou's work. There are a few other parameters to review in the course of selecting a monitor. Temperature range in which the monitor must function, monitor power demand, and humidity expected in the location are all important to monitor functionality. 
From these steps, with the types of gases and knowledge of the types of detectors available, it should be reasonably straightforward to select a monitor for the gases. Chou pointed out that the background gases are very important, since some types of gas detectors will be hampered by background gases and produce false readings due to the background gases. There are many detector brands available for the designer to choose from. The Thomas Register (www.thomasnet.com) lists many brands, including one of the most well known gas sampling companies, Dräger.

Chou (2000) also stated that gas monitors tend to be placed in two broad categories, toxic gas monitoring or combustible range monitoring. In general, toxic gas monitors are measuring concentrations for human health. They measure in a range up to 3 to 5 times above the permissible exposure limits, usually in tens of volume parts per million (ppm). Combustible range monitoring is generally up to $100 \%$ of the lower flammable limit (LFL), or a fraction of that, such as 50\% LFL. Such levels tend to be in the several percent of the atmosphere range, where $1 \%=10,000 \mathrm{ppm}$. 
Table 1. Parameters for several gases

\begin{tabular}{|c|c|c|c|c|c|c|c|c|}
\hline Gas & Formula & $\begin{array}{l}\text { Chemical } \\
\text { type }\end{array}$ & $\begin{array}{l}\text { General } \\
\text { hazards }\end{array}$ & $\begin{array}{l}\text { ACGIH } \\
\text { TLV } \\
(\mathrm{ppm})\end{array}$ & $\begin{array}{l}\text { ACGIH } \\
\text { STEL } \\
(\mathrm{ppm})\end{array}$ & $\begin{array}{l}\text { NIOSH } \\
\text { IDLH } \\
(\mathrm{ppm})\end{array}$ & $\begin{array}{l}\text { LFL- } \\
\text { UFL } \\
(\%)\end{array}$ & $\begin{array}{l}\text { LDL- } \\
\text { UDL } \\
(\%)\end{array}$ \\
\hline $\begin{array}{l}\text { Carbon } \\
\text { dioxide } \\
\mathrm{MW}=44\end{array}$ & $\mathrm{CO}_{2}$ & $\begin{array}{l}\text { non- } \\
\text { flammable } \\
\text { gas }\end{array}$ & asphyxiant & 5,000 & 30,000 & 40,000 & $\mathrm{n} / \mathrm{a}$ & $\mathrm{n} / \mathrm{a}$ \\
\hline $\begin{array}{l}\text { Carbon } \\
\text { monoxide } \\
\text { MW=28 }\end{array}$ & $\mathrm{CO}$ & flammable & $\begin{array}{l}\text { toxic, } \\
\text { combustible }\end{array}$ & 25 & none & 1,200 & $12.5-74$ & $\begin{array}{l}\text { not } \\
\text { found }\end{array}$ \\
\hline $\begin{array}{l}\text { Hydrogen } \\
M W=2\end{array}$ & $\mathrm{H}_{2}$ & flammable & $\begin{array}{l}\text { combustible } \\
\text { asphyxiant }\end{array}$ & $\begin{array}{l}\text { Not } \\
\text { listed }\end{array}$ & $\begin{array}{l}\text { not } \\
\text { listed }\end{array}$ & $\mathrm{n} / \mathrm{a}$ & $4-75$ & $18-59$ \\
\hline $\begin{array}{l}\text { Oxygen } \\
\text { MW=32 }\end{array}$ & $\mathrm{O}_{2}$ & oxidizer & toxic & $\mathrm{n} / \mathrm{a}$ & $\mathrm{n} / \mathrm{a}$ & $\mathrm{n} / \mathrm{a}$ & $\mathrm{n} / \mathrm{a}$ & $\mathrm{n} / \mathrm{a}$ \\
\hline
\end{tabular}

Notes: LDL and UDL mean lower detonation limit and upper detonation limit in air.

Some sources give the vapor density of a gas at STP, based on dry air vapor density=1, so values $>1$ are heavier than air and vice versa. Using the gas MW in $\mathrm{g} / \mathrm{mole}$ and $22.41 /$ mole volume at STP is also effective to determine which gas is lighter or heavier than air.

Data sources for Table 1:

NIOSH Pocket Guide to Chemical Hazards, NIOSH pub no. 2005-149, 2005.

Matheson Gas Data Book, seventh edition, McGraw Hill, New York, 2001, appendix 19.

W. E. Baker and M. J. Tang, Gas, Dust and Hybrid Explosions, Elsevier, 1991. 
Table 2. Typical Sensor Specifications

\begin{tabular}{|c|c|c|c|c|c|c|}
\hline $\begin{array}{l}\text { Sensor } \\
\text { type }\end{array}$ & $\begin{array}{l}\text { Temper } \\
\text {-ature } \\
\text { range } \\
(\mathrm{C})\end{array}$ & $\begin{array}{l}\text { Re- } \\
\text { sponse } \\
\text { time } \\
(\mathrm{s})\end{array}$ & $\begin{array}{l}\text { Accur- } \\
\text { acy } \\
( \pm \%)\end{array}$ & $\begin{array}{l}\text { Drift } \\
(\% / y r)\end{array}$ & $\begin{array}{l}\text { Life } \\
\text { Expec- } \\
\text { tancy (yrs) }\end{array}$ & Comments \\
\hline $\begin{array}{l}\text { Electro- } \\
\text { chemical } \\
\text { (oldest, } \\
\text { most } \\
\text { widely } \\
\text { recog- } \\
\text { nized } \\
\text { sensor) }\end{array}$ & $\begin{array}{ll}-40 & \text { to } \\
+45 & \end{array}$ & $<50$ & $1-2$ & $\begin{array}{l}24 \\
\text { can drift } \\
\text { down by } \\
2 \% \text { per } \\
\text { month }\end{array}$ & $\begin{array}{l}1 \text { to } 3 \\
\text { detector } \\
\text { head is } \\
\text { consumed } \\
\text { and needs } \\
\text { replacement }\end{array}$ & $\begin{array}{l}\text { Temperature sensitive, can misread } \\
\text { by } 0.5 \text { to } 1 \% \text { per }{ }^{\circ} \mathrm{C} \text { away from } \\
\text { calibration temperature. Humidity } \\
\text { does not affect the sensor. } \\
\text { Measures ppm ranges, well suited } \\
\text { for toxic gas sensing. About } 20 \\
\text { gases can be read by this sensor. }\end{array}$ \\
\hline $\begin{array}{l}\text { Diffusion } \\
\text { catalytic } \\
\text { bead }\end{array}$ & $\begin{array}{ll}-40 & \text { to } \\
+60 & \end{array}$ & $10-15$ & 5 & $5-10$ & $\begin{array}{l}\leq 3 \\
\text { detector } \\
\text { head is } \\
\text { consumed } \\
\text { and requires } \\
\text { replacement }\end{array}$ & $\begin{array}{l}\text { Used for over } 50 \text { years, for dozens } \\
\text { of combustible gases. Note that } \\
\text { the catalyst can be poisoned by } \\
\text { other gases or particulates in the } \\
\text { air. Well suited for use as portable } \\
\text { sensors. }\end{array}$ \\
\hline $\begin{array}{l}\text { Solid state } \\
\text { sensor }\end{array}$ & $\begin{array}{ll}-20 & \text { to } \\
+50 & \end{array}$ & $20-90$ & 3 to 10 & $\begin{array}{l}-- \\
\text { little } \\
\text { drift }\end{array}$ & $\begin{array}{l}\text { 10+ } \\
\text { when used in } \\
\text { clean } \\
\text { applications }\end{array}$ & $\begin{array}{l}\text { Used for more than } 120 \text { gases. } \\
\text { Susceptible to background gases } \\
\text { giving false alarms. Absorptive } \\
\text { filters reduce background gas false } \\
\text { alarms, but require periodic filter } \\
\text { replacement. }\end{array}$ \\
\hline $\begin{array}{l}\text { Infrared } \\
\text { sensor }\end{array}$ & $\begin{array}{ll}-40 & \text { to } \\
+60 & \end{array}$ & $<10$ & 1 & $\begin{array}{l}-- \\
\text { little } \\
\text { drift }\end{array}$ & $\begin{array}{l}3 \text { to } 5 \\
\text { for light } \\
\text { source, } \\
\text { detector can } \\
\text { operate }>10 \\
\text { yrs }\end{array}$ & $\begin{array}{l}\text { High sensitivity, from a few ppm } \\
\text { to } 100 \% \text { concentration, suitable for } \\
\text { toxic and combustible gases. Does } \\
\text { not react well to sudden temper- } \\
\text { ature variations in the room. Not } \\
\text { corroded or reacted by gas. The } \\
\text { most user friendly and least } \\
\text { maintenance monitor available. }\end{array}$ \\
\hline $\begin{array}{l}\text { Photo- } \\
\text { ionization } \\
\text { detector }\end{array}$ & $\begin{array}{ll}-20 & \text { to } \\
+50 & \end{array}$ & 3 & $1-10$ & $\begin{array}{l}\text { Up to } \\
30 \% \\
\text { humid- } \\
\text { ity drift }\end{array}$ & $\begin{array}{l}<1 \\
\text { for the UV } \\
\text { lamp }\end{array}$ & $\begin{array}{l}\text { Almost always used for detecting } \\
\text { volatile organic compounds } \\
\text { (VOCs) }\end{array}$ \\
\hline \multicolumn{7}{|c|}{ Toxic gases - Electrochemical and solid-state sensors are the most widely used } \\
\hline \multicolumn{7}{|c|}{ Combustible gases - Catalytic bead, solid-state, and infrared sensors are the most widely used } \\
\hline \multicolumn{7}{|c|}{$\begin{array}{l}\text { Data presented in this table are from Chou (2000). Mr. Chou is the President of International Sensor } \\
\text { Technology, Inc., Irvine, California. }\end{array}$} \\
\hline
\end{tabular}

Table 2 gives some information on numbers of gases that can be monitored by different types of gas monitors or sensors. Warren (1997) gave a list of over 380 commonly used industrial gases found in the chemical industry as well as in manufacturing, munitions, semiconductor fabrication, and other industries. Vendor literature will describe which sensors are sold to monitor specific gases. 


\section{Monitor Setpoints}

The INL safety manual section on compressed gases (INL, 2005) has adopted best practices in gas handling and use from the Occupational Safety and Health Administration (OSHA) in 29CFR1910, the Compressed Gas Association, and National Fire Protection Association (NFPA) standards 45, 51, and 55. With the list of all gases to be used or created in the laboratory and their expected volumes, the designer can check several documents to verify gas toxicity, i.e., any toxic chemical effects and the oxygen displacement (called a simple asphyxiant) or chemical asphyxia hazard (where a gas, such as $\mathrm{CO}$, chemically displaces oxygen from the blood) and the flammability or explosibility of each gas to generate data similar to those shown in Table 1. One document that can give such information for a wide variety of gases is the National Institute for Occupational Safety and Health (NIOSH) Pocket Guide to Hazardous Chemicals (NPG, 2005), which is available as a downloadable pdf from the NIOSH web site (www.cdc.gov/niosh/npg/). Other documents include Kuchta (2000), Zabetakis (2005), and Patnaik (1999). With the toxicity and flammability known, monitor setpoints can be chosen. A word of interpretation here, some gases can have a lower flammable limit (LFL), the lean limit, of some specific volume percentage in air, and span a large volume concentration range until the gas is too rich to burn in air (the upper flammable limit, UFL). The flammable limits and explosive limit are used interchangeably, since a deflagration in air is considered to be an explosion (Crowl, 2003; Bjerketvedt, 1997; Drysdale, 1985). Some gases can also have a highly explosive range in air within the flammable range, that is, detonation limits. Flammable means the gas can burn in a flash fire with almost no overpressure or can deflagrate (that is, combust via a subsonic combustion wave, rather than a supersonic detonation wave front) in air. A deflagration can be quite destructive itself without having a gas-air detonation event. The lower explosive limit is synonymous with the lower flammable limit because a flash fire or a deflagration (with just a few psi to up to $\sim 8$ atmospheres of overpressure) can be destructive; most buildings or confined spaces cannot withstand more than a few psi of overpressure, and humans themselves cannot stand more than a few atmospheres of overpressure without severe lung and gastrointestinal damage (AIChE, 1994). Gas detonation in air means a supersonic combustion wave and higher overpressures than deflagrations (up to $\sim 14$ atmospheres, Baker 1991); detonations are usually highly destructive but require high energy sources $(\sim \mathrm{kJ})$ to initiate rather than the milliJoule sparks that can ignite deflagrations. Most gases have a wide flammable range and a smaller detonation range, like shown in Table 1. For example, hydrogen has a 4\% to $74 \%$ volume mixture in air as its flammable range, and a smaller detonation range (18 to 59\%). Using LFL is safety conservative due to the damage created by a simple deflagration in air, and the fact that a detonation in air requires a higher gas concentration and a high energy ignition source, so detonations will be more rare events than flash fires or deflagrations. Whenever a standard or rule states the LEL, it is taken to mean the LFL, the lower deflagration limit.

NFPA Standard 55 states that a gas detection system shall alert persons on-site and a responsible person off-site when the gas concentration in the storage / use area reaches the US Occupational Safety and Health Administration (OSHA) Permissible Exposure Limit (PEL), OSHA ceiling limit (CL) for exposure or short term exposure limit (STEL) for the gas employed. Gas detection systems shall have a sensing interval not exceeding 5 minutes and provide a local alarm. The gas detection system shall monitor the exhaust system at the point of discharge from the gas cabinet, exhausted enclosure, or gas room. For gases used in unattended operation, an automatic valve shall close if the concentration of the gas reaches 
one-half of the Immediately Dangerous to Life or Health (IDLH) value for that gas. IDLH values are listed by NIOSH in their Pocket Guide to Hazardous Chemicals (NPG, 2005).

The US Department of Energy (DOE) has stated in the Code of Federal Regulations (CFR, 2006) and in its directive on worker safety (DOE, 1998) that when American Conference of Governmental Industrial Hygienists (ACGIH) Threshold Limit Values (TLVs) of respirable substances in air are lower (that is, more protective) than OSHA values, ACGIH values will be used. Even with that deviation from the law, contractors must still comply with other provisions cited in OSHA 29CFR1910. Table 3 gives values for some representative gases. In the case of carbon monoxide, using the more protective ACGIH value of $25 \mathrm{ppm}$ as a toxic gas monitor alarm setpoint should be adopted for a laboratory room with carbon monoxide present. The values for carbon dioxide are in agreement across organizations, so the OSHA PEL value of 5,000 ppm can be used for the alarm setpoint. In discussions with INL Environment, Safety and Health (ESH) personnel over the safety of a new National Hydrogen Initiative experiment being constructed in the Bonneville County Technology Center (BCTC) bay 9, the ESH personnel indicated that they desired using $50 \%$ of the TLV as a warning alarm setpoint for gases that have listed TLVs. Using $50 \%$ of the TLV as a warning alarm point is an INL-specific practice based on the DOE directive on worker safety (DOE, 1998) - it is driven by Battelle Energy Alliance requirements that are more conservative than the directions given in NFPA Standard 55. The 50\% TLV warning alarm was discussed during Independent Hazard Review meetings for the National Hydrogen Initiative experiments being placed into BCTC Bay 9.

The experimenters in BCTC Bay 9 questioned if it was possible to remain in the room to perform mitigation activities once the TLV value was reached, since the TLV is a level of exposure that can be tolerated by a nominally healthy worker for a typical 2,000 hour work year without harm. There is some latitude in the peak exposure to some gases that could allow for some extra time. As mentioned above, there are CL and STEL values for some gases, so rare exposures to greater than the TLV are possible; and the US DOE has also developed Temporary Emergency Exposure Limits (TEELs) (DOE, 2005). While these TEEL limits were developed for the general public (groups of persons that include the young and elderly, as well as infirm and healthy adults), they can also apply to staff if found allowable by ESH and management. However, with INL-specific requirements of a warning alarm at 50\% TLV and evacuation at $100 \%$ TLV values, the TEELs are not used. The time between attaining the $50 \%$ and $100 \%$ TLV alarm points can be used to isolate a leak, increase ventilation, "safe" (that is, safely shut down) the experiment apparatus, or other mitigative actions. Shifting the warning and evacuation alarms to lower gas concentrations maintains the safety and health of the experimenters and other INL or other authorized personnel who might be present during the experiment work.

Hydrogen gas is listed as a 'simple' asphyxiant gas by the ACGIH, rather than a 'chemical' asphyxiant. A simple asphyxiant gas is a gas that does not chemically asphyxiate humans; it merely displaces air to cause a lack-of-oxygen asphyxiation. A chemical asphyxiant would take the place of oxygen in blood or prevent oxygen from its proper interaction in the lungs or bloodstream. For simple asphyxiant gases, OSHA (2006) states that the definition of an oxygen deficient atmosphere is below $19.5 \% \mathrm{O}_{2}$ by volume, and that all oxygen deficient atmospheres shall be considered IDLH. An alarm and evacuation at the $19.5 \% \mathrm{O}_{2}$ level is typically performed. However, in the case of hydrogen, the simple asphyxiant gas is also a flammable gas. To obtain an oxygen decrease from the typical $20.9 \%$ to $19.5 \%$, a simple mole fraction of typical air $\left(78 \% \mathrm{~N}_{2}, 20.9 \% \mathrm{O}_{2}, 1 \%\right.$ Argon and traces of other gases) to air plus another gas in a non-ventilated room (resulting in $72.8 \% \mathrm{~N}_{2}, 19.5 \% \mathrm{O}_{2}, 0.93 \% \mathrm{Ar}$, and $6.7 \% \mathrm{H}_{2}$ ) shows that about $6.7 \%$ hydrogen at room temperature would need to be added to the non-ventilated room to reach IDLH oxygen levels, making the LFL at $4 \%$ a larger safety concern than the asphyxiation concern. The LFL for hydrogen in air is $4 \%$ by volume or $40,000 \mathrm{ppm}$. A hydrogen detector should be set to alarm at a fraction of the lower flammable limit (LFL) or lower explosive limit. ISA (2003) guidance states that a 
combustible gas monitor indicating up to the LFL should be set as low as possible commensurate with the need to avoid nuisance alarm signals.

The fraction of the LFL to use as the alarm setpoint is needed. The NFPA (Standards 30, 45, 55, 69, and 91) suggests that to prevent deflagrations, the combustible concentration limit be maintained at less than $25 \%$ of the LFL for the combustible gas, vapor, or mixture of gases. Gas detection monitors shall sound an alarm when the system detects vapors that reach or exceed $25 \%$ of the lower flammable limit. ANSI/ISA-TR12.24.01-1998, "Recommended Practice for Classification of Locations for Electrical Installations Classified as Class I, Zone 0, Zone 1, or Zone 2", Appendix D, states:

-An adequate number of sensors are installed to ensure the sensing of flammable gas or vapor in the building in all areas where such gas might accumulate

- sensing a gas concentration at $20 \%$ LFL or less should activate a local alarm (audible or visual or both, whatever is appropriate for the location)

- sensing a gas concentration of $40 \%$ LFL or less should activate a local alarm (audible or visual or both, whatever is appropriate for the location) and initiate automatic disconnection of power from all electrical devices in the area that are not rated for the gas environment.

-calibrate gas detectors at least once every three months

-bypass for calibration is allowed

- the building should not have any electrically heated parts or components outside of explosion-proof enclosures that may operate at a temperature equal to or above $80 \%$ of the ignition temperature of the gas or vapor

For many years, the traditional setpoints for warning alarm and evacuation alarm have been $20 \%$ of LFL and $40 \%$ of LFL (Anderson, 1999; TAC, 1984). Looking for other INL-specific experiences, the Advanced Test Reactor uses a hydrogen gas detector in the battery bank room, where the lead-acid batteries can evolve hydrogen gas. The room is ventilated and has one detector that is set to give operators an alarm at $20 \%$ of the LFL for hydrogen in air (SDD, 1993). The 20\%-40\% warning and evacuation alarm setpoints are also used by the American Petroleum Institute (API, 2002).

For hydrogen with a $4 \%$ LFL in air, one-quarter of the LFL is a $1 \%$ concentration of hydrogen by volume, or $10,000 \mathrm{ppm}$. A recent industrial trend is to set a warning alarm at a lower level, usually $10 \%$ of the lower flammable limit, to allow the staff to mitigate the event and bring the gas concentration back to acceptable levels and the typical alarm level of 20 or $25 \%$ LFL (Nolan, 1996). Some facilities have a special alarm function; if the gas concentration reaches $50 \%$ LFL, then the facility is shut down and depowered to preclude any deflagration damage (Vervalin, 1985). Confined space best practices also use $10 \%$ of the LFL or less as an acceptable limit for confined space atmospheres (ANSI, 2003a). A $10 \%$ LFL warning alarm is recommended for use in the laboratory.

It is also noted in Table 1 that $\mathrm{CO}$ is also a flammable gas, with a lower flammable limit in air of $12.5 \%$ by volume (Kuchta, 2000). $12.5 \%$ is $125,000 \mathrm{ppm}$, and $10 \%$ of that is $12,500 \mathrm{ppm}$. The carbon monoxide toxicity with a TLV of $25 \mathrm{ppm}$ is a much greater hazard than the flammability of the gas.

Considering suppression of nuisance alarms, the typical air concentrations of the gases listed in Table 1 are not well known. Carbon monoxide is the lowest of the values discussed, and may be the most sensitive. The Environmental Protection Agency states that the national primary ambient air quality standards for carbon monoxide are: $9 \mathrm{ppm}$ for an 8-hour average concentration (not to be exceeded more than once per year) and $35 \mathrm{ppm}$ for a 1-hour average concentration (not to be exceeded more than once per year) (EPA, 2004). If the air quality typically remains below $9 \mathrm{ppm}$ of $\mathrm{CO}$, then a $25 \mathrm{ppm}$ alarm level ( $\sim 3$ times the ambient concentration) should not result in nuisance alarms. The LFL of hydrogen 
gas in air is $4 \%$, so reducing the LFL by $90 \%$ for a " $10 \%$ LFL" warning alarm level gives $0.4 \%$ or 4,000 ppm, which should be a large enough value to preclude nuisance alarms. Pham (1998) stated that the lower the monitor setpoint, the more likely that a power surge, background noise, or some other interference would trigger an alarm. Keeping the alarm setpoints at or above $10 \%$ of transmitter full scale will reduce nuisance alarms. If more sensitivity (lower setpoint) is needed, then select a sensor with a small range (such as $50 \mathrm{ppm}$ full range versus $200 \mathrm{ppm}$ full range).

In summary, Table 4 gives some suggested gas monitor setpoints for prudent laboratory operations. An initial toxic gas warning at $50 \%$ of the TLV is used, and an evacuation alarm at $100 \%$ of the TLV concentration is used for personnel protection. Flammable gas warning alarms can be set at $10 \%$ of the LFL and an evacuation alarm at $25 \%$ of the LFL.

There is a concern about the low ppm setpoint value of carbon monoxide. The Environmental Protection Agency has a CO limit of $9 \mathrm{ppm}$ for an average 8-hour concentration that is not to be exceeded more than once per year (40CFR50.8) and generally, most office buildings are below that level. Given the instrument accuracies in Table 2, up to plus or minus $10 \%$, at $13 \mathrm{ppm}$ that is $\pm 1.3 \mathrm{ppm}$, so there should not be a high number of spurious, nuisance alarms. Carbon dioxide in air is on the order of a few hundred ppm (Chou, 2000), so the Table 5 alarm setpoint of 2,500 ppm is much higher than ambient levels and there should not be any spurious alarms.

It is also noted that oxygen enriched atmospheres are defined in OSHA as atmospheres containing more than $23.5 \%$ oxygen by volume (OSHA, 2006a). These oxygen concentrations are not particularly hazardous to breathe for short periods of time. Klaasen (1995) stated that short residence times of $\sim 3$ hours in $100 \%$ oxygen atmospheres are not debilitating or life threatening to healthy adults. The issue of importance for oxygen enrichment is that some materials, notably hydrocarbons such as oil, grease, and hydraulic fluids, are more highly flammable in high oxygen concentrations, some to the point of spontaneous flammability in oxygen enriched atmospheres (Cote, 1991). With oxygen oxidizer present, flames burn much hotter than in normal air and propagate at much greater speed; such fires often require extra water for extinguishment. The Compressed Gas Association gave a definition that $23 \%$ by volume of oxygen in air would be an oxygen-enriched hazardous atmosphere; however, at the INL the OSHA definition is recognized. The CGA definition is only a $2.1 \%$ oxygen increase over normal air; the OSHA definition is a $2.6 \%$ oxygen increase. Even "non-flammable" textiles used in protective clothing will burn fiercely in as little as $30 \%$ oxygen concentration by volume (CGA, 1992). 
Table 3. Occupational Exposure Values [ACGIH, 2006]

\begin{tabular}{|c|c|c|c|c|c|}
\hline $\begin{array}{ll}\text { Gas } & \text { of } \\
\text { Interest } & \\
\end{array}$ & $\begin{array}{l}\text { ACGIH } \\
\text { Threshold } \\
\text { Limit Value } \\
\text { (TLV) }\end{array}$ & $\begin{array}{l}\text { OSHA } \\
\text { Permissible } \\
\text { Exposure } \\
\text { Limit (PEL) }\end{array}$ & $\begin{array}{l}\text { NIOSH } \\
\text { Recommended } \\
\text { Exposure Limit } \\
\text { (REL) }\end{array}$ & $\begin{array}{l}\text { AIHA } \\
\text { Workplace } \\
\text { Environmental } \\
\text { Exposure Level } \\
\text { (WEEL) }\end{array}$ & Comments \\
\hline $\begin{array}{l}\text { Carbon } \\
\text { dioxide }\end{array}$ & $\begin{array}{l}5,000 \mathrm{ppm} \\
30,000 \mathrm{ppm} \text { as } \\
\text { STEL }\end{array}$ & $5,000 \mathrm{ppm}$ & $5,000 \mathrm{ppm}$ & Not listed & $\begin{array}{l}\text { NIOSH } \\
\text { IDLH is } \\
40,000 \mathrm{ppm}\end{array}$ \\
\hline $\begin{array}{l}\text { Carbon } \\
\text { monoxide }\end{array}$ & $25 \mathrm{ppm}$ & $50 \mathrm{ppm}$ & $35 \mathrm{ppm}$ & Not listed & $\begin{array}{l}\text { NIOSH } \\
\text { IDLH is } \\
1,200 \mathrm{ppm}\end{array}$ \\
\hline Hydrogen & $\begin{array}{l}\text { Simple } \\
\text { asphyxiant } \\
\text { gas, no TLV } \\
\text { concentration } \\
\text { given }\end{array}$ & Not given & Not given & Not listed & -- \\
\hline
\end{tabular}

Table 4. Suggested Alarm Setpoints for Industrial Gases in the BCTC Bay 9 Laboratory

\begin{tabular}{|l|l|l|l|}
\hline Gas of Interest & $\begin{array}{l}\text { Basis for setpoint } \\
\text { values }\end{array}$ & $\begin{array}{l}\text { Initial warning } \\
\text { alarm setpoint } \\
\text { (ppm) }\end{array}$ & $\begin{array}{l}\text { Evacuation } \\
\text { alarm setpoint (ppm) }\end{array}$ \\
\hline Hydrogen & $\begin{array}{l}\text { Flammability - } \\
10 \% \text { and 25\% of LFL }\end{array}$ & 4,000 & 10,000 \\
\hline Carbon dioxide & $\begin{array}{l}\text { Toxicity - 50\% TLV } \\
\text { and 100\% TLV }\end{array}$ & 2,500 & 5,000 \\
\hline $\begin{array}{l}\text { Carbon } \\
\text { monoxide }\end{array}$ & $\begin{array}{l}\text { Toxicity - 50\% TLV } \\
\text { and } 100 \% \text { TLV }\end{array}$ & 13 & 25 \\
\hline
\end{tabular}




\section{Monitor Placement.}

There is some guidance available about proper placement of monitors. The fixed point, stationary monitor can only function if the intruding gas contacts the monitor. Therefore, monitor placement is vital to proper monitoring of the room or area.

Using the molecular weight of the gas in question, as shown in the data presented in Table 1, allows identification of gases lighter than dry air (whose MW=28.9). Humid air is slightly less molecular weight. Therefore, the designer can easily identify if a gas will rise or settle when released. In some cases, if releasing a cold gas (perhaps a cryogenic gas), the gas will settle until it warms closer to room temperature, and it will mix with (dilute in) room air currents as it is warming.

ANSI/ISA-RP12.13.02 states that a fixed gas detection system should be installed so that it can monitor those parts of the plant or facility where flammable gases accidentally accumulate to create a significant hazard. The rationale for selecting sensor locations should be recorded. Factors in sensor location selection include: indoor or outdoor site, the location and nature of potential vapor/gas sources, chemical and physical data of the gases or vapors, liquids with volatility need sensors near the potential sources of release, nature and concentration of gas releases, natural and mechanical ventilation, detector installation locations not vulnerable to mechanical or water damage from normal operations, and locations that lend themselves to ready maintenance and calibration. The guidance also states that sensors should be located in all areas where hazardous accumulations of gas may occur. Such areas might not be close to release points but might be areas with restricted air movement. Heavier than air gases are likely to accumulate in pits, trenches, drains, and other low areas. Lighter than air gases are more likely to accumulate in overhead spaces, above drop ceilings, etc. In general, sensors should be located close to any potential sources of major release of gas. To avoid nuisance alarms, sensors should not be placed immediately adjacent to equipment that may produce inconsequential leakage during normal operation. Inconsequential leakage might include gas bottle racks where there are tiny releases during bottle changeout.

Process Industry Practices standard PIP PCCA001, "Design of Combustible and Toxic Gas Detection Systems", 2004, states that the detector location shall be appropriate to detect the presence of specified combustible or toxic gases (lighter or heavier than air) in the area the detector is installed. Point detectors shall normally be located adjacent to identifiable, single-spot, potential gas release locations having a significant risk of toxic or combustible gas leakage (i.e., pump and gas compressor seals, valves, etc.). Detectors shall be protected from direct sprays of oil and other liquid.

Jessel (2002) stated that there are three approaches to monitoring: spot, area, and fence monitoring. Spot monitoring is locating sensors near recognized sources of leakage (valves, nozzles, flanges, bellows, etc.). Spot monitoring makes judicious use of just a few monitors by identifying the most likely leak locations in the facility or system. Area monitoring means siting sensors at regular intervals throughout an area, similar to smoke detectors that are placed in grid patterns for fire protection. Area monitoring typically uses a larger number of sensors than spot monitoring. Jessel stated that for area monitoring, 500-1,000 square feet per monitor head is often used as a rule of thumb. TAC (1984) stated a recommendation that at least 1 sensor cover 900 square feet per room area monitor. Anderson (1999) stated that some manufacturers gave a recommendation of one sensor per 400 square feet. Obviously, there is variability in sensor coverage and placement. The third monitoring approach, fence or perimeter monitoring, is the design where four or more sensors are placed at the facility periphery to alarm that hazardous gases are leaving the site and intruding into neighboring areas. Perimeter monitoring is used more for an industrial complex than for a laboratory facility. 
Jessel points out that vapors from combustible liquids are always heavier than air, so they tend to stay close to the ground. Therefore, sensors to detect these vapors need to be close to the ground. The TAC (1984) recommended heavier-than-air gas sensor placement at $20-26$ inches above the low point or floor, and no higher than $42-48$ inches. Anderson (1999) suggested $12-18$ inches height from the floor or low point, and no higher than 36 inches. Gas sensor standards do not give specific distances. Jessel (2002) stated that only three combustible gases are significantly lighter than air: hydrogen, ammonia, and methane. Unless cryogenic, these gases tend to rise toward the ceiling and can form "gas nests" (i.e., gas pockets between beams, etc.). Toxic gases that are heavier than air or nearly neutral buoyancy in air, and are in small concentrations $<1 \%$ by volume, are moved by air currents and should be monitored at head height (in the breathing zone). For combustible gases or vapors, position the sensor between the leak source and any ignition sites if possible; if the sensor performs tasks such as de-energizing a process, starting ventilation fans, etc., then the sensor reaction time and countermeasure timing must be taken into account. Anderson (1999) and Chou (2000) stated that gases released into rooms are not predictable, and especially unpredictable when they are close to the density of air. Ventilation air currents in rooms are usually the largest motive force for gas movement in a room. Air currents can create anomalies in the expected gas movement and behavior. A sensor near an exit fan or exit duct, or at the ceiling or roof, is a prudent practice to detect lighter-than-air gases. Sensor placement near ventilation exit fans or outlet ducts is also prudent for gases with vapor densities similar to air.

Schaeffer $(1980,1981)$ gives some guidance on sensor placement as well. His work was also reproduced in TAC (1984) and Vervalin (1985). The Schaeffer sketches are reproduced here on the following pages to support the designer. Figures 1, 2, 3 and 4 depict the general behavior of a lighter-than-air gas in still air, a heavier-than-air gas in still air, a lighter-than-air gas under ventilation, and a heavier-than-air gas under ventilation. Figures 5, 6, and 7 depict three sketches of lighter-than-air gas releases. Figure 5 shows good monitor placement when ventilation air is not always present - near the ceiling, near a ventilation air return. In that way the sensor would detect gas going into the return duct when ventilation was operating and would continue to function when the ventilation system was not operating. Never mount a gas detector near a fresh air inlet duct, the fresh air inflow will not allow gas to reach the detector, and any inflowing particulate in the air flow will accumulate in the detector. Figure 6 shows a poor placement of a sensor in a ventilation return air line; if ventilation stopped, the sensor would not detect the leak into the room for many minutes, and with ventilation operating, adding air from multiple rooms will dilute the gas in the ventilation duct so that it might be too low in concentration to actuate the detector even though the gas is at a high concentration in the source room. Figure 7 depicts the lighterthan-air gas rising towards the ceiling, and that room air is much hotter near the ceiling. The warm air can delay the gas from reaching the ceiling since warmer air is less dense and density differences cause diffusion. Corsi (2000) described this phenomenon as the warm room and hot surfaces of the sunlit roof or ceiling as creating a "thermal barrier". However, hydrogen gas is the lightest gas, and room air that is 30 or $40 \mathrm{~F}$ hotter than ambient will not retard hydrogen diffusion to the same extent it would retard ammonia or methane diffusion. Also, if room ventilation moves this hot air, churning the hot air layer into the rest of the room air, then the concern for sensor delay is small.

The ISA-RP12.13.02 (ANSI, 2003), which was recommended by the National Electrical Code (NFPA 70), gave this guidance on sensor placement:

- Locate detectors above the level of ventilation openings and close to the ceiling for the detection of gases lighter than air

- If ceilings are compartmentalized by equipment or other obstructions, sensors should be installed in each compartment

- Account for thermally induced flow (e.g., hot surfaces on equipment) that may affect the distribution of gas in air 
- Place sensors in all areas where hazardous accumulations may occur; these areas may not be close to release points but may be in areas of restricted air movement

- Locate sensors close to potential areas of major release (to avoid nuisance alarms do not place immediately adjacent to equipment known to produce small leaks)

- Sensor orientation may be specified by the manufacturer

At least one INL laboratory has used fog to map the room air currents to help select radiation monitor placement (INL, 2006), and since the largest motive force for most gases is also the air currents in the room, similar work could be performed for laboratories if there is any question about gas monitor placement.

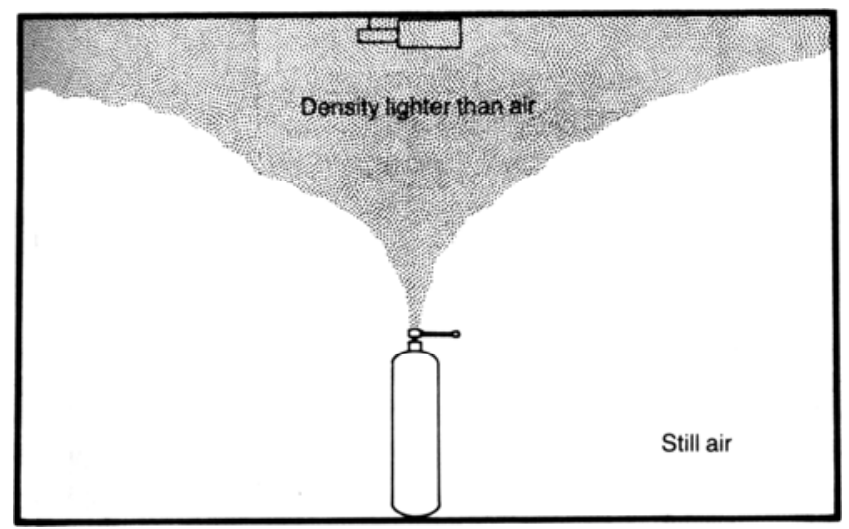

Figure 1. Lighter-than-air gas release into a non-ventilated room.

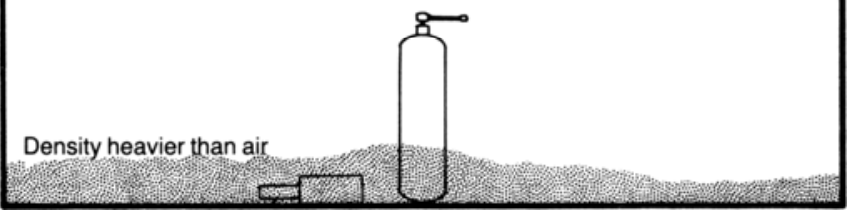

Figure 2. Heavier-than-air release into a non-ventilated room. 


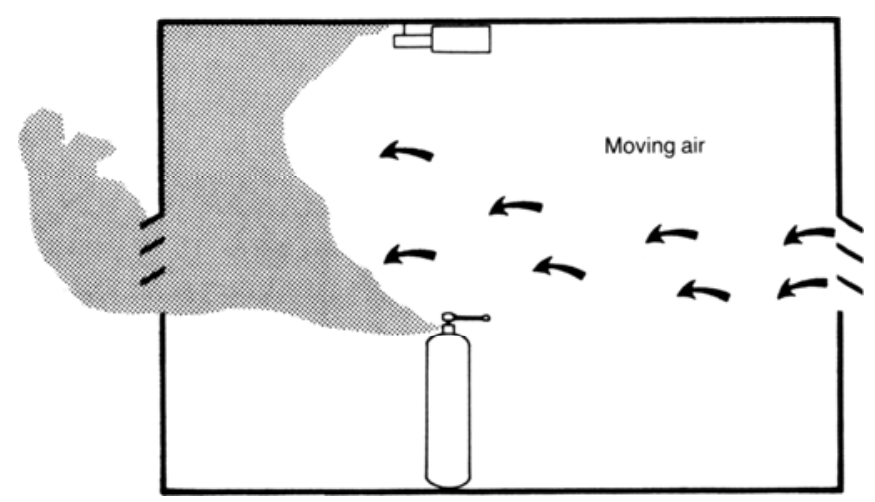

Figure 3. Lighter-than-air release into a ventilated room. Note that the air currents blanket the sensor and it does not detect the gas release.

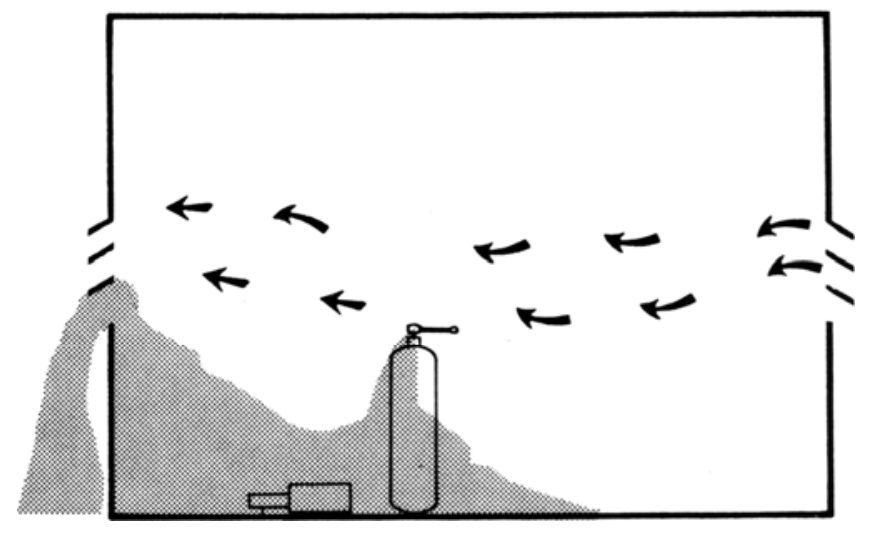

Figure 4. Heavier-than-air gas release into a ventilated room. Note that the sensor is placed such that it does detect the gas release.

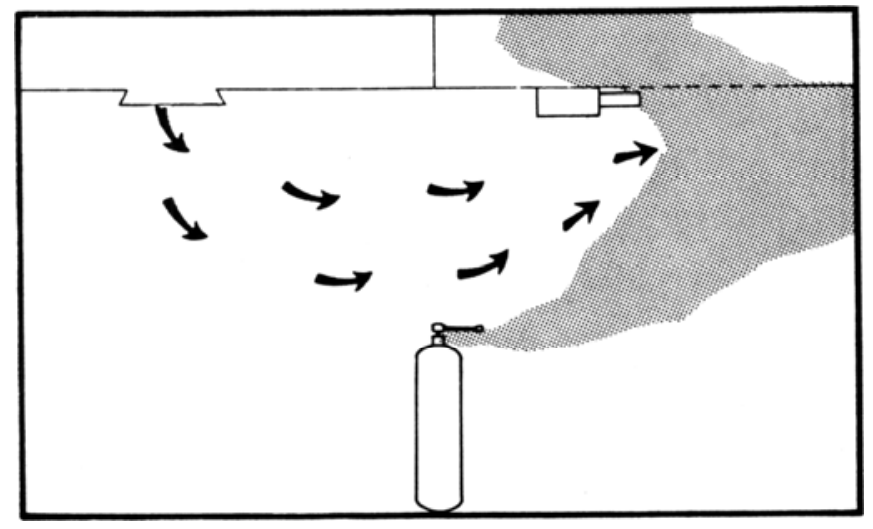

Figure 5. Lighter-than-air gas release into a ventilated room. Note that the sensor placement near the air outlet duct allows gas detection. 


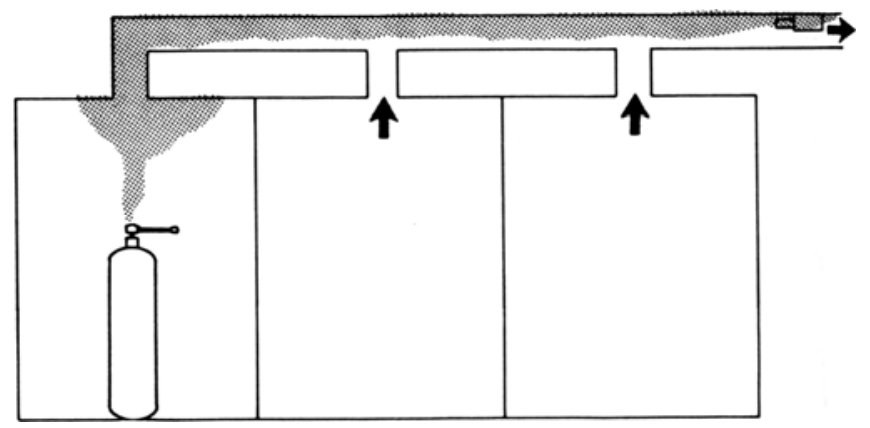

Figure 6. Lighter-than-air gas release into a ventilation duct network. Note that the air from other rooms dilutes the gas, so the concentration at the detector may be too low to trigger an alarm while the gas concentration in the room of release is high enough to alarm.

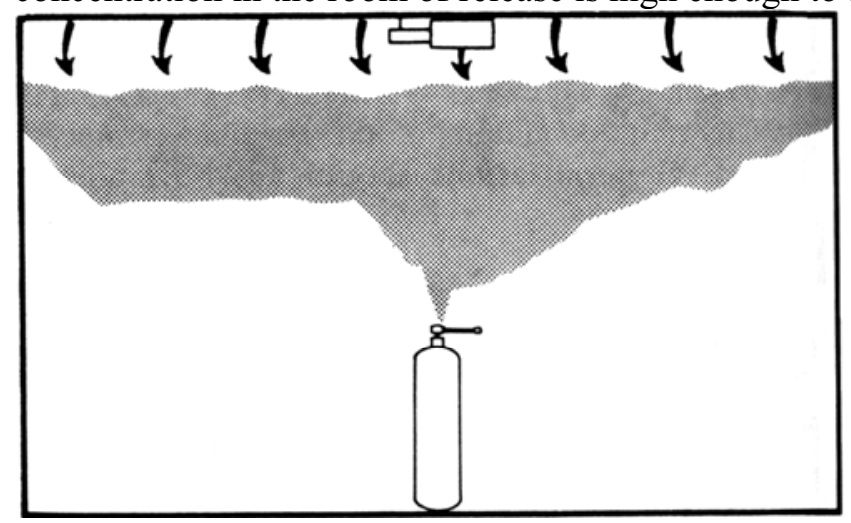

Figure 7. Lighter-than-air gas release into a room with a warm ceiling.

\section{Monitor usage tips.}

Gas monitors, depending on their type, can be susceptible to blockages of the detector element (i.e., dust, particulate from the air, water condensation, etc.), and catalyst units can be susceptible to compounds of silicon, phosphorous, chlorine, lead, and other elements (Nolan, 1996). Routine inspection and recalibration is necessary to keep the units operating correctly. Gas monitors can require reasonably frequent recalibration. Most of the literature examined for this task indicated that the manufacturer's recommendations should be followed. API (2002) states that gas monitors should be calibrated at a frequency in accordance with manufacturer's recommendations, but at least once every three months. Nolan (1996) concurs with the 3-month interval, and ANSI/ISA-TR12.24.01-1998 also stated that the gas detectors shall be calibrated at a frequency in accordance with the manufacturer's recommendations, but at least once every three months. For chemical process industry applications (sensors exposed to temperature extremes, weather, hydrocarbon emission fouling, etc.) the three-month interval is probably a wise precaution to keep the protective sensors operating. Calibration shall be performed with a known mixture (nominal 50\% LFL recommended) of diluent and methane or other gas anticipated, in accordance with the manufacturer's recommendations (API, 2002). The API also incorporates ANSI/ISA RP-12.13 (Installation, Operation, and Maintenance of Combustible Gas Detection Instruments) by reference.

Zdankiewicz (1997) gave some suggestions for routine maintenance: 
Gas Detector Head Routine Inspection and Maintenance

\begin{tabular}{|c|c|c|}
\hline Assembly or Function & Frequency & Procedure \\
\hline Sample connection & daily & $\begin{array}{l}\text { tighten probe or tube fitting as } \\
\text { needed }\end{array}$ \\
\hline Moisture trap & daily & drain and clean bowl \\
\hline Flow meter & daily & $\begin{array}{l}\text { check, adjust, replace dust filter as } \\
\text { needed }\end{array}$ \\
\hline Pump & daily & confirm operation and suction \\
\hline Alarm test & daily & check with test switch \\
\hline Detector output & daily & check for excessive output level \\
\hline Batteries (portable) & daily & $\begin{array}{l}\text { check remaining life and replace } \\
\text { as needed }\end{array}$ \\
\hline Alarm calibration & monthly & check with prepared gas sample \\
\hline Span adjustment & quarterly & $\begin{array}{l}\text { check and adjust with prepared } \\
\text { gas sample }\end{array}$ \\
\hline Zero calibration & quarterly & set with only clean air present \\
\hline Filter elements & twice/year & clean or replace as needed \\
\hline Sensor & twice/year & calibrate or replace \\
\hline
\end{tabular}

The ANSI/ISA-RP-12-13.02 (ANSI, 2003), which is referenced in NFPA Standard 70, suggested a regular inspection of the control panel, such as once per shift. A regular verification of the function of the lights, audible alarms and electronics by use of test switches was suggested, but no time interval was given. A typical calibration of the sensor should be performed regularly. The standard directed that calibration be performed in accordance with the manufacturer's instructions, using the recommended test kit and equipment, perform calibration on instrument commissioning and tested/re-calibrated at defined intervals thereafter, and regular inspections for malfunctions, damage or deterioration. Records should be kept for each detector head. For BCTC Bay 9, the manufacturer's recommendations in their manuals were 180 days for hydrogen sensors and six to twelve months for carbon dioxide monitors (Dräger, 2002).

Anderson (1999) stated that the calibration frequency varies with the manufacturer, sensor type, and the particular installation. For a catalytic bead-type sensor, a safe calibration interval can be chosen based on the changes in span and zero from the initial calibration, so recording these data and keeping them available for use are important for determining safe use of the monitors.

Chou (2000) stated that typically two calibrations are performed. One on the zero point, and another on the monitor span. For the zero point, that is, a zero concentration of the gas to be sensed, there is no established standard to define a practical 'zero' value. Many procedures call for use of dry nitrogen from gas cylinders, but dry nitrogen is not the same as air. The best approach suggested by Chou is to zero the monitor using ambient, typical humidity air - provided the air can be guaranteed as clean by portable monitors. This is the most realistic zero reference and the water vapor in air will give a true zero point for monitors. Dry gas will cause the zero point to be set lower than actual and then the monitor will appear to drift when no instrument drift has occurred. Span calibration is the second calibration to be performed. Chou stated that the best accuracy would be to mix target gas in background environmental air and use that as the calibration gas. However, that approach is complicated and expensive. The most popular method of span calibration is to use a premixed, dry calibration gas that is commercially available with a fixed concentration value of the target gas mixed into another bulk gas. Some calibration gases can be mixed with air, others can only be mixed with nitrogen or other inert gases. The calibration gas bottle is fitted with a regulator and flow restrictor. Flow rates of $600-1,000 \mathrm{cc} /$ minute at just 1-2 psig are common, with flows lasting a minute or more. Calibration gas bottle shelf life must be verified with the vendor, 
since many of these gas mixtures have short lifetimes in the bottles (gas reacts with bottle walls, etc.). The gas sensor reads from zero concentration and gives periodic readings up to the "span gas" or calibration gas concentration, thus the gas sensor reads through a span of concentrations. The monitor will be adjusted to read at the given percentage calibration gas level if the monitor gives an inaccurate reading during the calibration activity. This adjustment should be recorded. The span calibration is not a full range span, such as $0-100 \%$ LFL of a combustible gas in air. It is just the range up to the calibration gas volume percentage level, typically 50\% LFL for most combustible gases. The General Monitors corporation web site (at generalmonitors.com) gives a tutorial on calibration, and states that monitors will give a readout of remaining life of the sensor head. This percentage of remaining life should also be recorded. When a sensor head reaches low remaining lifetime, $20 \%$ or $10 \%$ remaining, it should be replaced and the new head given an initial calibration.

The calibration process is to attach a gas line to the monitor and send gas of known concentration from a bottle of calibration gas to the monitor and determine the time the monitor takes to read elevated gas levels, and note the highest level the monitor will read. Therefore, the sensor must be accessible, or calibrations may not be performed on schedule - according to the General Monitors website (generalmonitors.com). This calibration process works well for combustible gases mixed to some percentage (i.e., such as the typical 50\% LFL) in nitrogen or air. Toxic gases pose more difficult calibration issues. Anderson (1999) stated that two means are typically used for toxic gas monitor calibration, one is use of toxic gas ampoules. The ampoule approach may not be very accurate because ampoules are fragile and can leak, and the glass ampoule walls have been known to react with toxic gas. The ampoules are heated during the sealing process and heating can release contaminants from the glass, allowing contaminants to react later with the toxic gas after sealing has been completed. The second toxic gas calibration means is the same approach as combustible gases, delivering a known (but usually very small) concentration of the toxic gas or a similar toxic gas in a calibration gas from a cylinder to the monitor unit and taking a span reading.

The General Monitors web site stated that attention was needed for pits or trenches in floors, and alcoves, roof peaks, and dormers - all of which tend to be poorly ventilated and can accumulate leakage gases. Ventilation needs change with seasons, so all seasons must be taken into account when choosing monitor locations. Wiring sensors in series is often preformed because of cost savings in cabling and time, but such an approach results in cumulative outputs, difficulty in sensor calibration and reduced safety. One open circuit results in loss of all sensors, so individual wiring is costly but safety conservative. Sensors should not be placed in high vibration or high temperature areas; elevated levels of either vibration or temperature can reduce the monitor lifetime. Sensor wiring should be separate from alternating current wiring. Sensor wiring near high power AC wires will need electrical shielding, and the site also states it is good engineering practice to always used shielded (braided) cable. The shielded cable will prevent radio interference (i.e., walkie-talkie radios) and other interference with the sensor signals. Dust covers can be used in dirty areas, and splashguards in areas that are washed down or experience high levels of annual rainfall.

Another useful piece of information noted in the literature is the set of publications from the Matheson Gas Company. There are three publications that can be helpful to the designer and experimenter performing work for, or in, the laboratory. The Matheson Guide to Safe Handling of Compressed Gases (1983), the Effects of Exposure to Toxic Gases, First Aid and Medical Treatment (1988), and the Matheson Gas Data Book (2001) are important publications and are available at the INL technical library. For example, the gas data book contains an appendix regarding steps to follow if a gas cylinder begins to leak - shut the cylinder valve, and if it is safe to do so then disconnect the cylinder and move it outside (away from building air intakes, away from building wake effects created by wind, and away from internal combustion engines) to allow the cylinder to safely vent its contents. Matheson also provides a 
free downloadable pdf brochure "Safe Handling of Compressed Gases in the Laboratory and Plant" at its web site matheson-trigas.com.

These discussions should assist the designer when selecting and choosing locations for gas monitors, and setting up a gas monitor maintenance program. 


\section{References}

ACGIH, 2006. 2006 Guide to Occupational Exposure Values, American Conference of Governmental Industrial Hygienists, Cincinnati, Ohio, 2006 edition.

AIChE, 1994. Guidelines for Evaluating the Characteristics of Vapor Cloud Explosions, Flash Fires, and BLEVEs, American Institute of Chemical Engineers, Center for Chemical Process Safety, New York, 1994, appendix C.

Anderson, 1999. G. L. Anderson and D. M. Hadden, The Gas Monitoring Handbook, Avocet Press, Inc., New York, 1999.

ANSI, 2003. Recommended Practice for the Installation, Operation, and Maintenance of Combustible Gas Detection Instruments, ANSI/ISA-RP12.13.02-2003, American National Standards Institute/The Instrumentations, Systems, and Automation Society, Research Triangle Park, NC, February 26, 2003.

ANSI, 2003a. $\quad$ Safety Requirements for Confined Spaces, ANSI/ASSE Z117.1-2003, American Society of Safety Engineers, Des Plaines, IL, February 2003, section 6.

API, 2002. Recommended Practice for Classification of Locations for Electrical Installations at Petroleum Facilities Designated as Class I, Division 1 and Division 2, American Petroleum Institute, Recommended Practice 500, second edition, November 1997, reaffirmed November 2002 .

Baker, 1991. W. E. Baker and M. J. Tang, Gas, Dust and Hybrid Explosions, Elsevier, Amsterdam, 1991, chapter 3 .

Bjerketvedt, 1997. D. Bjerketvedt, J. R. Makke, K. van Wingerden, “Gas Explosion Handbook,” Journal of Hazardous Materials, 52 (1997) 1-150.

CFR, 2006. Title 10, Energy, Code of Federal Regulations, Subpart C - Specific Program Requirements, Part 851, "Worker Safety and Health Program," Section 23, "Safety and health standards," Washington, DC, June 28, 2006.

CGA, 1992. Accident Prevention in Oxygen-Rich and Oxygen-Deficient Atmospheres, CGA-P-14-1992, Compressed Gas Association, Inc., Arlington, Virginia, 1992.

Chou, 2000. J. Chou, Hazardous Gas Monitors: A Practical Guide to Selection, Operation, and Applications, McGraw-Hill Companies, Inc., New York, 2000.

Corsi, 2002. J. Corsi, "Area Monitoring of Hazardous Gases and Vapors," Sensors magazine, volume 17, January 2000. Available at www.sensorsmag.com.

Cote, 1991. A. E. Cote and J. L. Linville, Fire Protection Handbook, seventeenth edition, National Fire Protection Association, Quincy, MA, 1991, section 3, chapter 15.

Crowl, 2003. D. A. Crowl, Understanding Explosions, American Institute for Chemical Engineers, Center for Chemical Process Safety, New York, 2003, page 17. 
DOE, 1998. Worker Protection Management for DOE Federal and Contractor Employees, DOE O 440.1A, US Department of Energy, approved March 27, 1998.

DOE, 2005. US Department of Energy Chemical Safety Program, at www.eh.doe.gov/chem._safety/index.html. TEEL revision 21, November 9, 2005, document DKC-05-0002 by Douglas Craig of Savannah River Site.

Dräger, 2002. Polytron Transmitter IR $\mathrm{CO}_{2}$, IR $\mathrm{N}_{2} \mathrm{O}$, Instructions for Use, manual 9023656, second edition, December 2002; and Polytron 2 XP Ex, Transmitter for Catalytic Combustion Sensors, operating manual, manual 4543040, Draeger Safety, Inc., Pittsburgh, PA, 2002.

Drysdale, 1985. D. Drysdale, An Introduction to Fire Dynamics, John Wiley \& Sons, Inc., New York, 1985 , chapter 3.

EPA, 2004. Title 40, Protection of Environment, Code of Federal Regulations, Part 50, "National Primary and Secondary Ambient Air Quality Standards," Section 8, "National primary ambient air quality standards for carbon monoxide," Washington, DC, August 3, 2004.

INL, 2005. "Handling and Use of Compressed Gases," INL document LRD-14303, Laboratory Wide Manual 14A Volume I - Safety, Fire Protection, Industrial Hygiene, Idaho National Laboratory, Idaho Falls, ID, September 29, 2005.

INL, 2006. TRA-666 STAR Facility Air Flow Study and Recommended Sampling Points for Airborne Radioactivity, EDF-4438, Idaho National Laboratory, Idaho Falls, ID, March 2006.

ISA, 2003. Recommended Practice for the Installation, Operation, and Maintenance of Combustible Gas Detection Instruments, ANSI/ISA-RP 12.13.02-2003, Section 6.9.3 "adjustment of alarm set points", The Instrumentation, Systems, and Automation Society, Research Triangle Park, NC, February 26, 2003.

Jessel, 2002. W. Jessel, "Planning and Designing Gas Detection Systems," Sensors magazine, volume 19, January 2002. Available at www.sensorsmag.com.

Klaasen, 1995. C. D. Klaasen (editor), Casarett \& Doull's Toxicology, the basic science of poisons, McGraw-Hill, New York, 1995, chapter 24.

Kuchta, 2000. J. M. Kuchta, Investigation of Fire and Explosion Accidents in the Chemical, Mining, and Fuel-Related Industries - A Manual by Kuchta, ANSI/ISA-TR12.12.02-1999, approved January $1,2000$.

Nolan, 1996. D. P. Nolan, Handbook of Fire and Explosion Protection Engineering Principles for Oil, Gas, Chemical, and Related Facilities, Noyes Publications, Westwood, NJ, 1996, chapter 17.

NPG, 2005. NIOSH Pocket Guide to Chemical Hazards, DHHS (NIOSH) Publication 2005-149, National Institute for Occupational Safety and Health, Department of Health and Human Services, Washington, DC, September 2005.

OSHA, 2006. Title 29, Labor, Code of Federal Regulations, Subpart I - Personal Protective Equipment, Part 1910, "Occupational Safety and Health Standards," Section 134, "Respiratory protection," Washington, DC, July 5, 2006. 
OSHA, 2006a. Title 29, Labor, Code of Federal Regulations, Subpart J - General Environmental

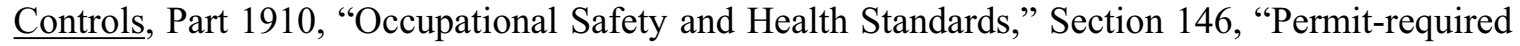
Confined Spaces,” Washington, DC, July 5, 2006.

NFPA 69. Standard on Explosion Prevention Systems 2002 Edition, chapter 6, National Fire Protection Association, Quincy, MA, 2002.

NFPA 91. Standard for Exhaust Systems for Air Conveying of Vapors, Gases, Mists, and Noncombustible Particulate Solids 2002 Edition, chapter 4, National Fire Protection Association, Quincy, MA, 2002.

NFPA 30. Flammable and Combustible Liquids Code 2003 Edition, chapter 4, National Fire Protection Association, Quincy, MA, 2003.

NFPA 45. Standard on Fire Protection for Laboratories Using Chemicals 2004 Edition, chapter 10, National Fire Protection Association, Quincy, MA, 2004.

NFPA 70. National Electrical Code 2005 Edition, National Fire Protection Association, Quincy, MA, 2004.

NFPA 55. Standard for the Storage, Use, and Handling of Compressed Gases and Cryogenic Fluids in Portable and Stationary Containers, Cylinders, and Tanks 2005 Edition, National Fire Protection Association, Quincy, MA, 2005.

P. Patnaik, A Comprehensive Guide to the Hazardous Properties of Chemical Substances, second edition, John Wiley Sons, NY, 1999.

Pham, 1998. L. P. Pham and D. A. Pryor, "Toxics and Combustibles: Designing Gas-Detection Systems," Chemical Engineering, 105 (July 1998) 80-86.

Schaeffer, 1980. J. Schaeffer, "Use Flammable Vapor Sensors?, Hydrocarbon Processing, 60 (January 1980) 211-220.

Schaeffer, 1981. J. Schaeffer, "The Use of Combustible Detectors in Protecting Facilities from Flammable Hazards," ISA Transactions, 20 (1981) 25-30.

SDD, 1993. Power Reactor Programs, System Design Description, Battery-Backed Power System, SDD 7.3.3, INEL, July 15, 1993.

TAC, 1984. Safety Handbook for Hydrogen Sulfide Gas and Flammable Gases, Texas Analytical Controls, Inc., Stafford, Texas, 1984.

Vervalin, 1985. C. H. Vervalin, Fire Protection Manual for Hydrocarbon Processing Plants, third edition, volume 1, Gulf Publishing Company, Houston, TX, 1985, page 456.

Warren, 1997. P. Warren, Hazardous Gases and Fumes, a Safety Handbook, Butterworth Heinemann, Oxford, 1997.

Zabetakis, 2005. M. G. Zabetakis, Flammability Characteristics of Combustible Gases and Vapors, ANSI/ISA-TR12.13.01-1999, reaffirmed August 31, 2005. 
Zdankiewicz, 1997. E. M. Zdankiewicz, "Gas Detection in Theory and in Practice, Part II: The Gas Detector Head," Sensors magazine, 14 (November 1997) 46-54. 
Appendix B

\section{INL Laboratory Instruction (Li) of the Hydrogen/Oxygen Generating Laboratory System}




\section{APPENDIX B: INL LABORATORY INSTRUCTION (LI) OF THE HYDROGEN/OXYGEN GENERATING LABORATORY SYSTEM \\ \begin{tabular}{|l|l|l|lr}
\hline Nuclear Science and Technology & Laboratory Instruction & USE TYPE 4 & ECR Number: 557374
\end{tabular}}

\section{PURPOSE/SCOPE/APPLICABILITY}

\section{PROGRAM OBJECTIVES:}

The primary objective of this project is to develop and demonstrate high-temperature steam electrolysis for efficient hydrogen production using solid-oxide electrolysis cells.

The Integrated Laboratory Scale (ILS) facility will demonstrate higher hydrogen production rates while simultaneously addressing integral issues such as multiple-stack gas manifolding, stack electrical integration, inlet/outlet gas handling, and thermal management. Previous bench-scale tests have primarily concentrated on quantifying material and cell performance and have not addressed larger-scale issues such as thermal management (feed-stock heating and high-temperature gas handling), multiple-stack hotzone design, multiple-stack electrical configurations, and other "integral" issues. The Integrated Laboratory Scale (ILS) experiment is designed to address these larger-scale integral issues. For the multiple-stack tests that will be performed in the ILS, inlet gas flows will be preheated upstream of the primary hot zone. The ILS will also implement heat recuperation and hydrogen recycle as practical.

\section{PROJECT APPROACH:}

The ILS electrolyzer will consist of three modules, each comprised of four 60 -cell stacks. Figure 1 is a CAD rendering of one 4-stack module. All three modules will be located within a single hot zone as shown in Figure 2. Typical operating temperature for the hot zone is $830^{\circ} \mathrm{C}$. The electrolysis modules require support systems supplying electrical power for electrolysis, a feedstock gas mixture of hydrogen and steam, a sweep gas, and appropriate exhaust handling. The gas handling system must include means for controlled steam generation, mixing hydrogen (and possibly nitrogen) with the steam, feedstock and product dew point measurements, heating the feedstock and sweep gas to the appropriate electrolysis temperature, cooling the electrolysis product stream, condensing any residual steam out of the product stream, and venting both the hydrogen product and sweep gas stream.

The ILS is designed such that each electrolysis module has its own independent support and instrumentation system. The feedstock and product gas streams for each electrolysis module are monitored and controlled separately and thus the inlet and outlet gas composition and flow rate is known independently for each module. If a module fails during operation, that particular module can be shut down without affecting the safe performance or testing of the other modules. And since each module is operated and monitored separately, each module can support different operating conditions (e.g., gas flow rates, operating voltage, current density, etc.) simultaneously. In this way, a test matrix covering a wide range of operating conditions can be covered more quickly. 


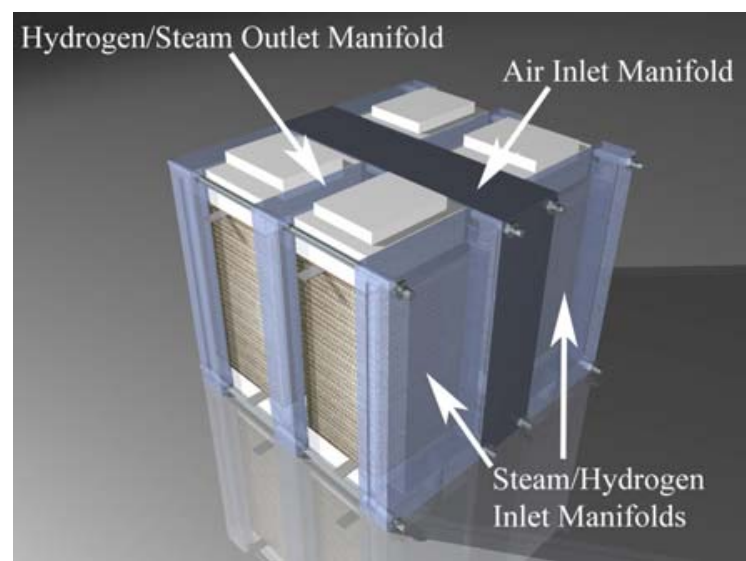

Figure 1. ILS 4-Stack Module.

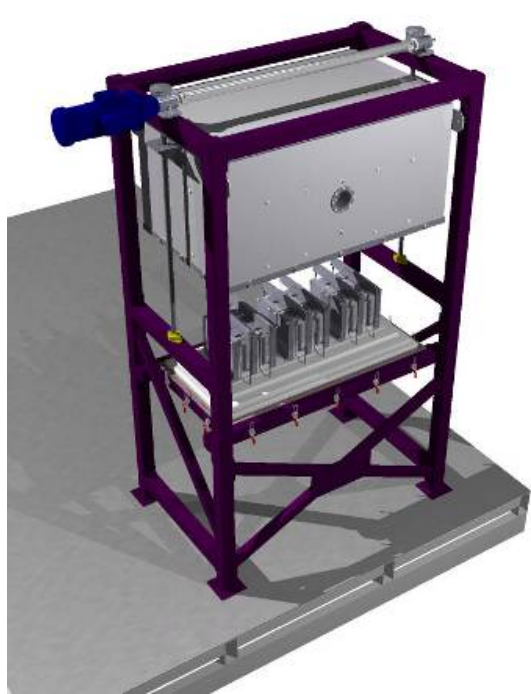

Figure 2. THE ILS Hot Zone.

\section{3.. PROJECT/ACTIVITY DESCRIPTION:}

\section{ILS MECHANICAL DESIGN}

The Piping and Instrumentation Diagram (P\&ID) for the ILS is shown in Figures 3. Figure 4 presents a rendering of the ILS configuration from various viewpoints. As discussed above, separate parallel support systems are included for each electrolysis module. All three parallel support systems are depicted in Figures 3 and 4 . Note that there is only one sweep-gas stream emerging from the hot-zone enclosure. This one stream handles sweep-gas exhaust for all three modules.

\section{ILS DESIGN}

In Fig. 3 and 4, the hydrogen/steam feedstock is represented by the color magenta, the product stream by orange, the inlet sweep gas by green, and the outlet sweep gas by blue. 


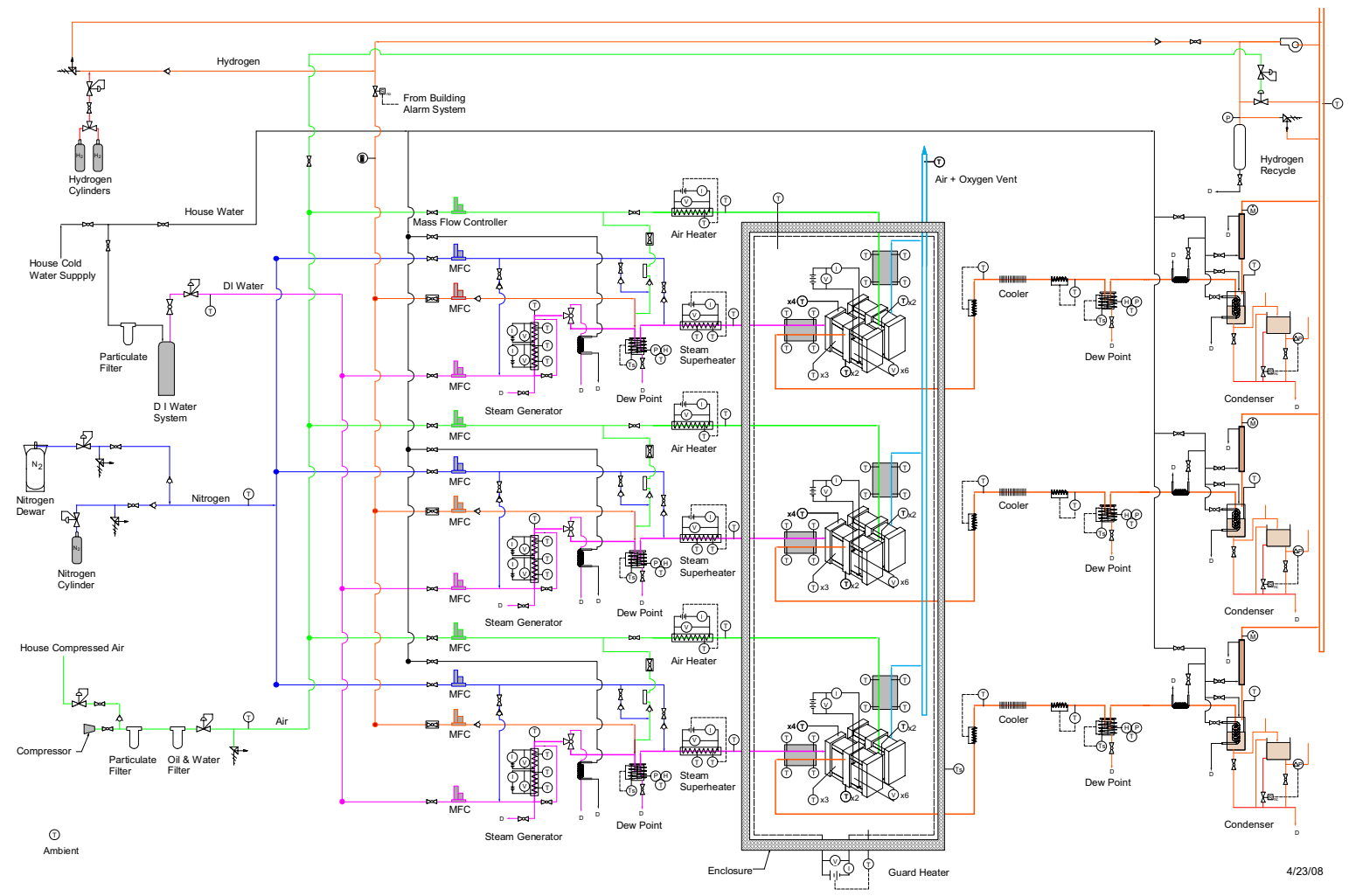

Figure 3. Piping and Instrumentation Diagram.

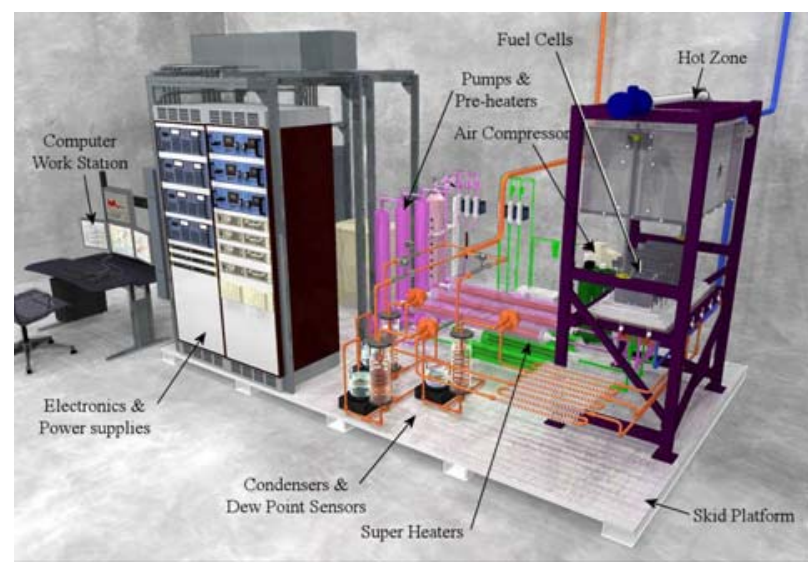

Front View

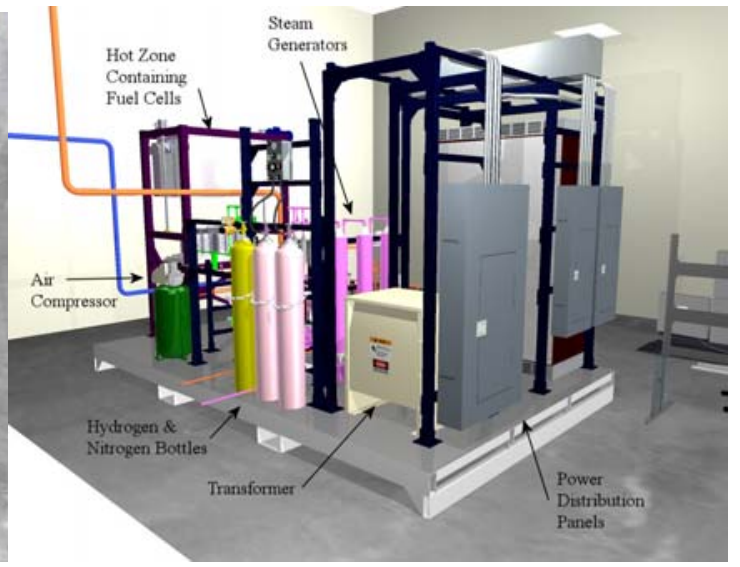

Rear View

Figure 4. Rendering of the INL ILS facility.

\section{HIGH TEMPERATURE ELECTROLYSIS PROCESS}

iquid water feedstock is fed at a controlled rate into the system. The water is then vaporized and slightly superheated in an in-line electrically powered steam generator. The steam exiting the steam generator is mixed with hydrogen (and possibly nitrogen), which is required on the inlet side of the stack in order to maintain reducing conditions at the steam/hydrogen electrode. The inlet hydrogen will be supplied from a compressed-gas cylinder. The hydrogen flow rate is controlled by a mass-flow controller coupled to the 
Data Acquisition and Control System (DACS). The inlet hydrogen must be heated to the steam generator outlet temperature in order to prevent cooling of the steam and possible steam condensation. Downstream of the mixing point, the temperature, pressure, and dew-point temperature of the gas mixtures are measured. Absolute pressure is directly measured at each dew-point measurement station to allow accurate determination of the steam mole fraction. Precise measurement of the dew-point and pressure allows for independent determination of the inlet gas composition. A high-temperature electrically powered in-line superheater then boosts the feedstock stream to the final electrolyzer operating temperature, $800^{\circ}-830^{\circ} \mathrm{C}$.

The gas mixture exiting the electrolyzer will be significantly enriched in hydrogen, typically to at least $50 \%$ hydrogen mole fraction. The product stream is first cooled via natural convection using sections of finned tubing in ambient air. The product stream temperature exiting this cooler is controlled such that no condensation can occur. Then the product gas mixture enters the outlet dew-point measurement station. The outlet hydrogen/steam flow then enters a condenser where the vast majority of the residual steam is removed. The rate of water condensation will be monitored with an online measuring system, providing an additional independent measure of steam consumption. At this point, the product stream will be ambienttemperature, saturated hydrogen gas (plus possibly some nitrogen), with about $3 \%$ residual water vapor. The flow rate of this product gas will be measured with a low-pressure-drop mass flow transducer. Comparison of the condensate and product mass flow rates with the electrolyzer inlet mass flow rates helps quantify any stack leakage that may occur. The hydrogen product will then be vented from the building.

Air will be used as a sweep gas for the ILS system. Compressed air, after flowing through moisture and debris filters, flows through a mass-flow controller and into an electrically powered superheater to preheat the inlet air to the stack operating temperature. Downstream of the electrolyzer, the hot oxygen-enriched air stream is vented from the building.

For hydrogen recycle, a line will be tapped upstream of the vent to provide hydrogen to be mixed with the inlet steam feedstock for the electrolysis process. Again, the remaining hydrogen product will be vented from the building. 


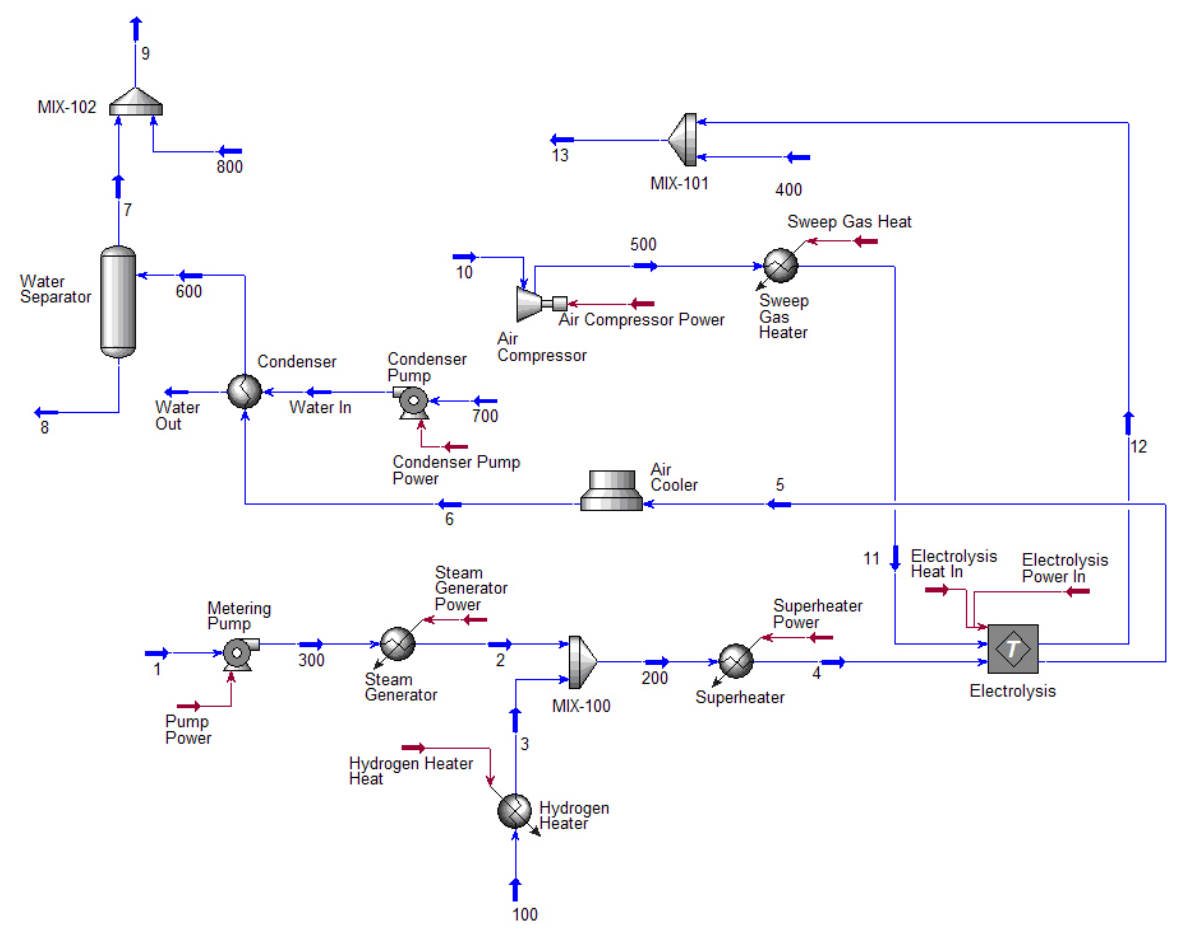

Figure 5. UniSim ILS process model.

Detailed process flow sheets were developed for the ILS design using the commercial system-analysis code UniSim. Figure 5 is a diagram of the system simulated by UniSim. These flow sheets include all of the components that will be present in the actual ILS system such as pumps, heat exchangers, and the electrolyzer. The UniSim simulations provided process temperature, mixture compositions, and flow rates for all of the flow streams. Process information obtained from the model for the nominal and extreme design cases are listed in Table 1 and Table 2. The values in Table 1 are the result of the UniSim simulation. This simulation code is an intuitive and interactive process modeling tool that creates steadystate and dynamic models for the project design, performance monitoring, troubleshooting, operational improvement, business planning and asset management. It was not an estimated maximum production rate. Component and total requirements are listed in Table 3. Note that these values are totals for the three parallel systems.

Table 1. UniSim simulation process information.

\begin{tabular}{|l|l|l|}
\hline & Nominal Design Case & Extreme Design Case \\
\hline Area Specific Resistance (ASR) $\left(\mathrm{ohm} \mathrm{cm}{ }^{2}\right)$ & 1.5 & 1.0 \\
\hline Current Density $\left(\mathrm{amps} / \mathrm{cm}^{2}\right)$ & 0.25 & 0.37 \\
\hline Per-cell Voltage (thermal neutral, volts) & 1.283 & 1.283 \\
\hline Electrolysis Power $(\mathrm{kW})$ & 14.54 & 21.8 \\
\hline Hydrogen Production Rate (NL/hr) & 4735 & 7103 \\
\hline
\end{tabular}


Table 2. UniSim simulation process stream conditions (no $\mathrm{N}_{2}$ in inlet process stream).

\begin{tabular}{|c|c|c|c|c|c|c|}
\hline \multirow{2}{*}{$\begin{array}{l}\text { Stream } \\
\text { No. }\end{array}$} & \multirow{2}{*}{$\begin{array}{l}\text { Temperature } \\
\left({ }^{\circ} \mathrm{C}\right)\end{array}$} & \multirow{2}{*}{$\begin{array}{ll}\text { Mass } & \\
\text { Flow } & \text { Rate } \\
(\mathrm{g} / \mathrm{s}) & \\
\end{array}$} & \multicolumn{4}{|c|}{ Component Mole Fractions } \\
\hline & & & $\mathbf{H}_{2}$ & $\mathrm{H}_{2} \mathbf{O}$ & $\mathbf{O}_{2}$ & $\mathbf{N}_{2}$ \\
\hline \multicolumn{7}{|c|}{ Nominal Design Case $\left(A S R=1.5 \mathrm{ohm} \mathrm{cm}^{2}\right)$} \\
\hline 1 & 15.56 & 2.116 & 0 & 1 & 0 & 0 \\
\hline 2 & 112.6 & 2.116 & 0 & 1 & 0 & 0 \\
\hline 3 & 113.5 & 0.0263 & 1 & 0 & 0 & 0 \\
\hline 4 & 830 & 2.142 & 0.1 & 0.9 & $\mathrm{n} / \mathrm{a}$ & $\mathrm{n} / \mathrm{a}$ \\
\hline 5 & 830 & 1.202 & 0.55 & 0.45 & $\mathrm{n} / \mathrm{a}$ & $\mathrm{n} / \mathrm{a}$ \\
\hline 6 & 92 & 1.202 & 0.55 & 0.45 & $\mathrm{n} / \mathrm{a}$ & $\mathrm{n} / \mathrm{a}$ \\
\hline 7 & 32 & 0.1948 & 0.9627 & 0.0373 & $\mathrm{n} / \mathrm{a}$ & $\mathrm{n} / \mathrm{a}$ \\
\hline 8 & 32 & 1.008 & 0 & 1 & 0 & 0 \\
\hline 9 & 25.28 & 50.00 & 0.04 & 0.0016 & 0.2008 & 0.7576 \\
\hline 10 & 25 & 1.4635 & & & 0.2095 & 0.7905 \\
\hline 11 & 830 & 1.4635 & & & 0.2095 & 0.7905 \\
\hline 12 & 830 & 2.403 & 0 & 0 & 0.5 & 0.5 \\
\hline 13 & 39.58 & 139.5 & & & 0.214 & 0.786 \\
\hline \multicolumn{7}{|c|}{ Extreme Design Case $\left(\mathrm{ASR}=1.0 \mathrm{ohm} \mathrm{cm}^{2}\right)$} \\
\hline 1 & 15.56 & 3.173 & 0 & 1 & 0 & 0 \\
\hline 2 & 112.6 & 3.173 & 0 & 1 & 0 & 0 \\
\hline 3 & 113.5 & 0.0395 & 1 & 0 & 0 & 0 \\
\hline 4 & 830 & 3.213 & 0.1 & 0.9 & $\mathrm{n} / \mathrm{a}$ & $\mathrm{n} / \mathrm{a}$ \\
\hline 5 & 830 & 1.804 & 0.55 & 0.45 & $\mathrm{n} / \mathrm{a}$ & $\mathrm{n} / \mathrm{a}$ \\
\hline 6 & 92.0 & 1.804 & 0.55 & 0.45 & $\mathrm{n} / \mathrm{a}$ & $\mathrm{n} / \mathrm{a}$ \\
\hline 7 & 32 & 0.2922 & 0.9627 & 0.0373 & $\mathrm{n} / \mathrm{a}$ & $\mathrm{n} / \mathrm{a}$ \\
\hline 8 & 32 & 1.512 & 0 & 1 & $\mathrm{n} / \mathrm{a}$ & $\mathrm{n} / \mathrm{a}$ \\
\hline 9 & 25.28 & 75.06 & 0.04 & 0.0016 & 0.2008 & 0.7576 \\
\hline 10 & 25 & 2.195 & & & 0.2095 & 0.7905 \\
\hline 11 & 830 & 2.195 & & & 0.2095 & 0.7905 \\
\hline 12 & 830 & 3.604 & & & 0.5 & 0.5 \\
\hline 13 & 39.58 & 209.3 & & & 0.214 & 0.786 \\
\hline
\end{tabular}


Table 3. UniSim simulation component-specific utility requirements information.

\begin{tabular}{|l|l|l|}
\hline \multirow{2}{*}{ Component } & Primary Utility Requirements \\
\cline { 2 - 3 } & $\begin{array}{l}\text { Nominal Design Case } \\
\left(\mathrm{ASR}=1.5 \mathrm{ohm} \mathrm{cm}^{2}\right)\end{array}$ & $\begin{array}{l}\text { Extreme Design Case } \\
\left(\mathrm{ASR}=1.0 \mathrm{ohm} \mathrm{cm}^{2}\right)\end{array}$ \\
\hline Feed Water Metering Pump $(\mathrm{kW})$ & 0.0002 & 0.0003 \\
\hline Water Requirement $(\mathrm{gm} / \mathrm{s})$ & 2.116 & 3.173 \\
\hline Steam Generator $(\mathrm{kW})$ & 5.637 & 8.455 \\
\hline Steam/Hydrogen Superheater $(\mathrm{kW})$ & 3.511 & 5.266 \\
\hline Hot Zone Guard Heaters $(\mathrm{kW})$ & 10 & 10 \\
\hline Steam/Hydrogen Cooler $(\mathrm{duty}, \mathrm{kW})$ & 3.226 & 4.839 \\
\hline Cooling Air Requirement $(\mathrm{gm} / \mathrm{s})$ & 120 & 180 \\
\hline Steam/Hydrogen Condenser $(\mathrm{duty}, \mathrm{kW})$ & 2.705 & 4.058 \\
\hline Cooling Water Requirement $(\mathrm{gm} / \mathrm{s})$ & 44.1 & 66 \\
\hline Air Sweep Gas Compressor $(\mathrm{kW})$ & 0.077 & 0.1155 \\
\hline Air Sweep Gas Superheater $(\mathrm{kW})$ & 1.2 & 1.801 \\
\hline Electrolyzer $(\mathrm{kW})$ & 14.54 & 21.8 \\
\hline Total Electrical $(\mathrm{kW})$ & 35.0 & 47.5 \\
\hline Total Water, including feedstock $(\mathrm{gm} / \mathrm{s})$ & 46.2 & 69.2 \\
\hline
\end{tabular}

\section{INSTRUMENTATION \& CONTROL CONFIGURATION}

The instrumentation and control system for the ILS will be comprised of:

- Temperature measurement and control - temperature measurements will be obtained using thermocouples wired into the DASC and temperature control will be performed using LabVIEW software (see below).

- Pressure measurement - pressure measurements will be obtained from pressure transducers.

- Flow rate measurement and control (gas and liquid) - flow rates for both gases and liquids will be obtained from mass flow controllers and control will be performed with LabVIEW software.

- Dew-point measurement - dew-point measurements will be obtained with humidity and temperature sensors.

- Electrolysis electrical power supply and control - electrical power will be controlled with programmable power supplies;

- Data acquisition and control system (DACS) - signals from all thermocouple channels, mass-flow controllers, pressure transducers, and cell voltage taps will be wired into a modular DACS. Programmable power supplies will also be configured for control and monitoring by the DACS system. The DASC serves as a power supply, communication conduit, and chassis control circuit for managing various analog signal-conditioning modules as well as analog signal output modules.

- Computer control - control of the above DACS system will be implemented using a personal computer and the LabVIEW software. In addition to the DACS, the LabVIEW software will also coordinate communications and control of the various serial interface devices as well. LabVIEW programs will serve as the graphical user interface for operation and control of the ILS, provide on-screen real-time graphical data representation, and will log experimental test data to disk. 
4. MAJOR EQUIPMENT USED IN ACTIVITY:

\begin{tabular}{|c|c|c|}
\hline Major Item & Instruction Manual & Instruction Manual location \\
\hline Compressed gas cylinders & $\begin{array}{lcc}\begin{array}{l}\text { Training } \\
\text { compressed } \\
\text { (TRN1041) }\end{array} & \text { for } & \text { handling } \\
\text { (Tylinders }\end{array}$ & NA \\
\hline Hot Zone & $\begin{array}{l}\text { None (in-house design using } \\
\text { Watlow Ceramic heaters) }\end{array}$ & $\begin{array}{l}\text { Ceramic heater instruction } \\
\text { sheets are located in File } \\
\text { Cabinet }\end{array}$ \\
\hline Hot Zone Lid Screw Jacks & 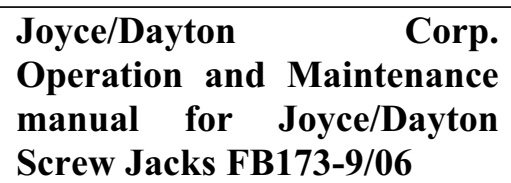 & $\begin{array}{l}\text { File cabinet under BCTC } \\
\text { Color Laser HP } 5550 D N \\
\text { Printer (near deep sink on } \\
\text { west wall) }\end{array}$ \\
\hline Proce & \multirow{4}{*}{ None (in-house design) } & \multirow{4}{*}{ NA } \\
\hline $\begin{array}{l}\text { Recuper } \\
\text { exchange }\end{array}$ & & \\
\hline Cooler & & \\
\hline & & \\
\hline $\begin{array}{l}\text { DC Power Supply No. } 1 \text { (Hot } \\
\text { Zone ICHS Fiber Embedded } \\
\text { Guard Heaters) } \\
\text { DC Power Supplies Nos. 2, } 3 \\
\text { \& } 4 \text { (Modules 1, 2, \& } 3 \\
\text { [stacks]) }\end{array}$ & $\begin{array}{l}\text { Lambda EMI Instruction } \\
\text { Manual for 10kW - 15 kW } \\
\text { ESS Power Supply 83-481- } \\
004\end{array}$ & $\begin{array}{l}\text { File cabinet in the high-bay } \\
\text { on the south wall of the office } \\
\text { next to the office door }\end{array}$ \\
\hline $\begin{array}{l}\text { DC Power Supplies Nos. 5, 6, } \\
\& 7 \text { (Steam Generator - Top) }\end{array}$ & $\begin{array}{l}\text { Lambda Americas Technical } \\
\text { Manual for Genesys }{ }^{\mathrm{TM}} \\
\text { 750W/1500W Programmable } \\
\text { DC Power Supplies } \\
\text { Document: 83-507-013 RevA }\end{array}$ & $\begin{array}{l}\text { File cabinet in the high-bay } \\
\text { on the south wall of the office } \\
\text { next to the office door }\end{array}$ \\
\hline $\begin{array}{l}\text { DC Power Supplies Nos. 8, } 9 \\
\& 10 \text { (Steam Generator - } \\
\text { Bottom) }\end{array}$ & $\begin{array}{l}\text { Lambda EMI Operator } \\
\text { Manual for EMS Power } \\
\text { Supply 83-473-000 Revision } \\
\text { L }\end{array}$ & $\begin{array}{l}\text { File cabinet in the high- } \\
\text { bay on the south wall of } \\
\text { the office next to the office } \\
\text { door }\end{array}$ \\
\hline $\begin{array}{l}\text { DC Power Supplies } \\
\text { Nos. 11, } \\
\text { 12, \& } \& \text { (Steam } \\
\text { Superheaters) }\end{array}$ & $\begin{array}{l}\text { Lambda Americas Technical } \\
\text { Manual for 2U Genesys }{ }^{\mathrm{M}} \\
3 . .3 \mathrm{~kW} \text { Programmable DC } \\
\text { Power Supplies Document: } \\
\text { 83-503-001 rev B) }\end{array}$ & $\begin{array}{l}\text { File cabinet in the high-bay } \\
\text { on the south wall of the office } \\
\text { next to the office door }\end{array}$ \\
\hline Mass Flow Controllers & $\begin{array}{l}\text { Bronkhorst Coriolis Mass } \\
\text { Flow Meters manuals (TBD) }\end{array}$ & $\begin{array}{l}\text { File cabinet in the high-bay } \\
\text { on the south wall of the office } \\
\text { next to the office door }\end{array}$ \\
\hline Air compressor & $\begin{array}{l}\text { Ingersol Rand SS3L3 } \\
\text { Owner's Manual with Parts } \\
\text { List CCN: 22204929, Rev A, } \\
\text { October 2002 }\end{array}$ & $\begin{array}{l}\text { File cabinet under } \text { BCTC } \\
\text { Color Laser HP } 5550 D N \\
\text { Printer (near deep sink on } \\
\text { west wall) } \\
\end{array}$ \\
\hline $\begin{array}{l}\text { Data Acquisition and C } \\
\text { System (DASC) }\end{array}$ & $\begin{array}{l}\text { National Instruments SCXI- } \\
1124 \text { User Manual }\end{array}$ & $\begin{array}{l}\text { File cabinet in the high- } \\
\text { bay on the south wall of } \\
\text { the office next to the office } \\
\text { door }\end{array}$ \\
\hline
\end{tabular}


5. ACTIVITY LOCATION BY AREA, BUILDING NUMBER AND LAB ROOM NUMBER:

REC 670-BCTC Bay 9

6. ACTIVITY QUALITY LEVEL AND QL DATABASE NUMBER:

Quality Level 3, Database No. STC-000029

7. ACTIVITY LAB MANAGER, LABORATORY SPACE COORDINATOR, AND PRINCIPAL INVESTIGATOR:

Laboratory Manager: James R. Wolf

Laboratory Space Coordinator: Kevin G. DeWall

Principal Investigator: Carl M. Stoots 


\section{RISK AND CONTROLS}

Table 2.01.

\begin{tabular}{|c|c|c|c|c|c|}
\hline Task & $\begin{array}{l}\text { Skill of } \\
\text { Perfor } \\
\text { mer }\end{array}$ & Hazard & Engineering Control & $\begin{array}{l}\text { Administrative } \\
\text { Control }\end{array}$ & $\begin{array}{l}\text { Personal } \\
\text { Protective } \\
\text { Equipment } \\
\text { (PPE) }\end{array}$ \\
\hline $\begin{array}{l}\text { Load and } \\
\text { transport } \\
\text { compressed } \\
\text { gas } \\
\text { cylinders }\end{array}$ & & $\begin{array}{l}\text { Back injury } \\
\text { or strained } \\
\text { muscles, } \\
\text { Falling } \\
\text { cylinders }\end{array}$ & $\begin{array}{l}\text { Use material handling } \\
\text { devices whenever } \\
\text { possible, do not lift more } \\
\text { than } 50 \text { lbs. get help to } \\
\text { move heavy cylinders, do } \\
\text { not bend and twist while } \\
\text { lifting. Use the upright } \\
\text { spin roll to move } \\
\text { cylinders by hand where } \\
\text { necessary. } \\
\text { Secure cylinders to } \\
\text { transport device ensure } \\
\text { valve cap is in place. Use } \\
\text { a transport device or } \\
\text { vehicle suitable to } \\
\text { transport cylinders. }\end{array}$ & $\begin{array}{l}\text { Training } \\
\text { (Compressed Gas } \\
\text { Cylinder } \\
\text { Handling } \\
\text { TRN1041 and } \\
\text { Industrial } \\
\text { Ergonomics } \\
\text { 00INL838) }\end{array}$ & $\begin{array}{l}\text { Safety shoes } \\
\text { or protective } \\
\text { toe caps, } \\
\text { leather gloves, } \\
\text { and safety } \\
\text { glasses }\end{array}$ \\
\hline $\begin{array}{l}\text { Connecting } \\
\text { cylinder } \\
\text { gages. }\end{array}$ & & $\begin{array}{l}\text { Exploding } \\
\text { or flying } \\
\text { parts under } \\
\text { pressure, } \\
\text { damage to } \\
\text { cylinder }\end{array}$ & $\begin{array}{l}\text { Do not use oil on threads, } \\
\text { use correct gages, stand } \\
\text { to side and open valve } \\
\text { slowly }\end{array}$ & & $\begin{array}{lr}\text { Wear } & \text { safety } \\
\text { glasses } & \text { and } \\
\text { gloves } & \end{array}$ \\
\hline $\begin{array}{l}\text { Storage of } \\
\text { cylinders }\end{array}$ & & $\begin{array}{l}\text { Explosion } \\
\text { or damage } \\
\text { to cylinder }\end{array}$ & $\begin{array}{l}\text { Store in designated } \\
\text { storage areas, secure } \\
\text { cylinders to prevent } \\
\text { falling over, protect from } \\
\text { direct sunlight, segregate } \\
\text { flammable gases and } \\
\text { oxidizers with a fire } \\
\text { barrier or by a distance of } \\
20 \text { feet. Move cylinders } \\
\text { to storage when cylinders } \\
\text { are not in use. Store with } \\
\text { caps on, assure cylinders } \\
\text { are labeled correctly and } \\
\text { have a full or empty tag, } \\
\text { Assure storage area is } \\
\text { properly posted including } \\
\text { the hazard information } \\
\text { for the cylinders. }\end{array}$ & & \\
\hline
\end{tabular}




\begin{tabular}{|c|c|c|c|c|}
\hline $\begin{array}{l}\mathrm{H}_{2} \\
\text { handling }\end{array}$ & $\begin{array}{l}\text { Fire and } \\
\text { explosion }\end{array}$ & $\begin{array}{l}\mathrm{H}_{2} \text { gas is vented directly } \\
\text { outside the laboratory; } \\
\text { laboratory monitoring } \\
\text { system will alarm if LFL } \\
\text { of } 4 \% \mathrm{H}_{2} \text { concentration is } \\
\text { approached. Air supply } \\
\text { lines and hydrogen } \\
\text { supply lines are } \\
\text { controlled by locked } \\
\text { valves with key control } \\
\text { by the PI and nitrogen is } \\
\text { used to purge the inlet } \\
\text { lines after impurities are } \\
\text { purged with heated air. }\end{array}$ & 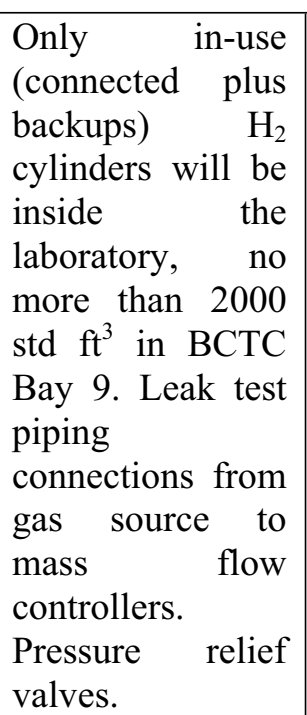 & Safety glasses \\
\hline $\begin{array}{l}\mathrm{O}_{2} \\
\text { handling }\end{array}$ & $\begin{array}{l}\text { Fire and } \\
\text { explosion }\end{array}$ & $\begin{array}{l}\mathrm{O}_{2} \text { gas is vented directly } \\
\text { outside of the laboratory; } \\
\text { laboratory monitoring } \\
\text { system will alarm if } \\
\text { enriched } \mathrm{O}_{2} \text { limit is } \\
\text { approached }\end{array}$ & $\begin{array}{l}\text { Pressure relief } \\
\text { valves }\end{array}$ & Safety glasses \\
\hline $\begin{array}{l}\text { Unattended } \\
\text { experiment } \\
\mathrm{s}\end{array}$ & $\begin{array}{l}\text { Damage to } \\
\text { experiment } \\
\text {, failure of } \\
\text { experiment } \\
\text { hazardous } \\
\text { gas leak }\end{array}$ & $\begin{array}{l}\text { Upset or utility failure } \\
\text { will not result in a } \\
\text { situation that requires } \\
\text { emergency personnel to } \\
\text { take action. Laboratory } \\
\text { gas monitoring system } \\
\text { will shutdown experiment } \\
\text { and notify WCC in case } \\
\text { of alarm. }\end{array}$ & & \\
\hline $\begin{array}{l}\text { Safety } \\
\text { equipment } \\
\text { calibration }\end{array}$ & $\begin{array}{l}\text { Improper } \\
\text { operation } \\
\text { of } \\
\text { laboratory } \\
\text { gas } \\
\text { monitoring } \\
\text { system }\end{array}$ & & $\begin{array}{l}\text { The vendor } \\
\text { (PRAXAIR) is } \\
\text { under contract to } \\
\text { calibrate the } \\
\text { system for } 3 \\
\text { years at an } \\
\text { interval of every } \\
6 \text { months. The } \\
\text { contract will be } \\
\text { renewed at the } \\
\text { end of the three } \\
\text { year period. } \\
\text { Calibration will } \\
\text { be documented in } \\
\text { the Dräger Safety } \\
\text { gas Monitoring } \\
\text { System binder. }\end{array}$ & \\
\hline
\end{tabular}




\begin{tabular}{|c|c|c|c|c|}
\hline $\begin{array}{l}\text { Working } \\
\text { near hot } \\
\text { surfaces }\end{array}$ & Burns & & $\begin{array}{lr}\text { Post } & \text { caution } \\
\text { signs and } \\
\text { establish safety } \\
\text { barrier around the } \\
\text { HTE-ILS skid. }\end{array}$ & $\begin{array}{l}\text { Thermal } \\
\text { protective } \\
\text { gloves }\end{array}$ \\
\hline $\begin{array}{l}\text { Chemical } \\
\text { handling }\end{array}$ & $\begin{array}{l}\text { Skin or eye } \\
\text { contact }\end{array}$ & & Training & $\begin{array}{lr}\text { Safety } & \text { glasses } \\
\text { and } & \text { nitrile } \\
\text { gloves } & \\
\end{array}$ \\
\hline $\begin{array}{l}\text { Assembly } \\
\text { of } \\
\text { electrical } \\
\text { equipment }\end{array}$ & $\begin{array}{l}\text { Electrical } \\
\text { shock }\end{array}$ & & $\begin{array}{l}\text { QUAL } \\
\text { QNRDREWT } \\
\text { De-energize } \\
\text { electrical energy } \\
\text { by un-plugging } \\
\text { cord-connected } \\
\text { equipment and } \\
\text { instruments and } \\
\text { maintain } \\
\text { exclusive control } \\
\text { of plug and cord } \\
\text { (within eye sight } \\
\text { and arms reach) }\end{array}$ & $\begin{array}{l}\text { Leather gloves } \\
\text { may be worn }\end{array}$ \\
\hline $\begin{array}{l}\text { Performing } \\
\text { service, } \\
\text { maintenanc } \\
\text { e, or } \\
\text { modificatio } \\
\text { ns under } \\
\text { Lockout/ } \\
\text { Tagout } \\
\text { conditions }\end{array}$ & $\begin{array}{l}\text { Unexpecte } \\
d \text { release of } \\
\text { hazardous } \\
\text { energy } \\
\text { resulting in } \\
\text { injury to } \\
\text { personnel }\end{array}$ & & $\begin{array}{l}\text { QUAL } \\
\text { QNLTWORK }\end{array}$ & \\
\hline $\begin{array}{l}\text { Operate air } \\
\text { compressor }\end{array}$ & $\begin{array}{l}\text { Unexpecte } \\
\mathrm{d} \text { release of } \\
\text { hazardous } \\
\text { energy (air } \\
\text { pressure) } \\
\text { resulting in } \\
\text { injury to } \\
\text { personnel }\end{array}$ & $\begin{array}{lr}\text { Pressure vessel } & \text { inspection } \\
\text { in accordance } & \text { with BEA } \\
\text { Owner/User } & \text { Pressure } \\
\text { Vessel } & \text { Inspection } \\
\text { Program. r Present } & \text { Pertificate rexpires } \\
\text { 03/26/2010. Compressor } \\
\text { will be re-inspected as } \\
\text { required. }\end{array}$ & $\begin{array}{l}\text { Pressure Vessel } \\
\text { Inspection } \\
\text { Certificate } \\
\text { attached to } \\
\text { compressor. } \\
\text { Pressure-relief } \\
\text { valve }\end{array}$ & \\
\hline $\begin{array}{l}\text { Handling } \\
\text { insulation } \\
\text { material }\end{array}$ & $\begin{array}{l}\text { Inhalation } \\
\text { and skin } \\
\text { contact } \\
\text { with } \\
\text { dust/fibers } \\
\text { from } \\
\text { insulation }\end{array}$ & $\begin{array}{l}\text { Portable HEPA-filtered, } \\
\text { localized exhaust } \\
\text { ventilation placed in } \\
\text { immediate work area }\end{array}$ & & $\begin{array}{l}\text { Safety glasses, } \\
\text { nitrile gloves } \\
\text { and lab coats }\end{array}$ \\
\hline
\end{tabular}


Table 2.02.

\section{Hazard scenarios that require mitigation.}

\section{Buildup of a potentially explosive hydrogen gas mixture}

Hydrogen gas mixed with air can create an explosive hazard. This potential hazard will be mitigated by confining the hydrogen gas within a fully sealed flow system. The tubing and components through which hydrogen will flow will be fully leak-checked before operation. During electrolysis testing, a small amount of hydrogen gas will be mixed with steam, heated and sent to the electrolysis cells. Electrolysis generated hydrogen will increase outlet hydrogen concentrations to above $50 \%$ hydrogen mole fraction, with the remainder being residual steam. The condenser removes the residual steam and the hydrogen product will then be vented from the building. The following possible hazard scenarios are considered:

- Accidental release of hydrogen from a single compressed gas cylinder. In this case, the laboratory air in BCTC Bay 9 (approximately 55,000 $\mathrm{ft}^{3}$ ) would achieve a hydrogen concentration of less than $0.5 \%$, assuming it is uniformly distributed and taking no credit for air turnover in the lab from the ventilation system. This is well below the LFL of $4 \%$.

- Mixing of air and hydrogen during startup. Heated air is used to purge the supply lines from the dew-point sensors to the outlet of the modules of impurities that may accumulate during fabrication, assembly, maintenance or repairs. The air used for this purge must be removed from the system before hydrogen is introduced to preclude the unsafe mixing of air and hydrogen to a combustible combination. To preclude this from occurring, the air supply line valves AND the hydrogen supply line valves for each module that control gas inlet to the modules, are controlled by key-locked valves with key control by the PI. One valve on each module must be closed and locked so that only one gas can be supplied to the dew-point sensors. An Experiment Test Plan will be developed for each production test that will describe procedures for start-up and operation of the system to include the conduct of the hot-air purge and operation of these valves. Additionally, upon completion of the heated air purge, the hydrogen inlet supply line from the dew-point sensors to the module outlets are purged with nitrogen to remove residual air.

- Leakage of electrolytically produced hydrogen. At a high hydrogen production rate from the ILS of $9.2 \mathrm{~m}^{3} / \mathrm{hr}$ (this production rate value is not intended to establish a maximum allowable production rate), it would take 7 hours to reach the LFL of $4 \%$, assuming that all the hydrogen produced is leaked into the laboratory space, ignoring ventilation and hydrogen buoyancy effects, etc.

- Mechanical failure of the electrolysis cell (leakage of hydrogen from the cathode side of the cell (hydrogen/steam) to the anode side (air) during heat up). This hazard will be mitigated by supplying an air flow to the anode side of the electrolysis cell during heat up that will ensure that, even if the hydrogen mixes with air, the composition of the hydrogen/air mixture well below $4 \%$ hydrogen. Once the hot zone achieves temperatures above $\sim 550{ }^{\circ} \mathrm{C}$ (auto-ignition temperature for hydrogen) the explosion potential no longer exists, since any hydrogen that mixes with air at high temperature will immediately react with the oxygen in a simple diffusion flame, with no potential for buildup or explosion.

- The potential explosion hazard associated with the use and production of hydrogen gas will be further mitigated by the means of the laboratory gas monitoring system. A hydrogen sensor is located above the ILS at the ceiling level. This system will provide a warning alarm at $10 \%$ of the LFL to alert laboratory personnel of a problem and provide sufficient time to correct the problem or shut down the ILS prior to reaching the evacuation level. The system will provide an evacuation alarm at $25 \%$ of the LFL. At this level, automatic shut-off valves will be activated to terminate inlet hydrogen flow. In addition, relays will open on the electrolyzer power to put the electrolyzer in open-cell status, with zero hydrogen production. This 


\section{Buildup of high oxygen levels}

Elevated oxygen levels have the potential to make other materials more flammable. Oxygenenriched atmospheres are defined as those containing more than $23.5 \%$ oxygen by volume. Electrolytically generated oxygen can increase outlet oxygen concentrations to levels as high as $50 \%$ oxygen mole fraction. This oxygen-enriched air stream will be vented from the building. The hydrogen vent and oxygen vent have been placed more than 20 feet apart.

- One possible hazard scenario would involve leakage of electrolytically produced oxygen into the laboratory. At a high production rate of $3.8 \mathrm{~m}^{3} / \mathrm{hr}$ (this production rate is not intended to establish a maximum allowable production rate), it would take 11 hours to reach the enriched oxygen limit of $23.5 \%$ in the laboratory, assuming that all the oxygen produced is leaked into the laboratory space and initial oxygen levels are normal atmospheric concentrations (20.9\%) and that no fresh air is introduced into the laboratory.

- The potential fire hazard associated with the use and production of oxygen gas will be further mitigated by the means of the laboratory gas monitoring system. An oxygen sensor is located near the ILS. This system will provide a warning alarm at $22.5 \%$ enriched oxygen to alert laboratory personnel of a problem and provide sufficient time to correct the problem or shut down the ILS prior to reaching the evacuation level. The system will provide an evacuation alarm at $23.5 \%$ enriched oxygen. At this level, automatic shut-off valves will be activated to terminate inlet hydrogen flow. In addition, relays will open on the electrolyzer power to put the electrolyzer in open-cell status, with zero oxygen production. This contingency will minimize risk associated with unattended operation.

\section{Evacuation alarm procedure}

If a gas hazard evacuation alarm sounds, the researchers will exit the laboratory immediately. The procedures in GDE-252, BCTC Bay 9 Emergency Response Guide, will be followed in the event of hazardous gas alarm activation in the laboratory.

\section{Compressed gas hazards}

Compressed gas hazards will be mitigated by following the procedures outlined in JSA\# 56-03INEEL, Compressed Gas Cylinder Handling. Researchers will stay current with compressed gas training (TRN1041). In addition, the gas-flow system is designed to be inherently safe with regard to over-pressurization events.

- Maximum line pressure will be $40 \mathrm{psig}$, which is where the gas-bottle regulators will be set. Non-adjustable relief valves with a relief pressure of $50 \mathrm{psig}$ are located immediately down stream of each regulator to guard against the unlikely event of regulator failure exposing the system to pressures higher than the maximum rated regulator outlet pressure.

- The mass-flow meters and tubing downstream of the regulators and upstream of the mass-flow controllers are rated at $275 \mathrm{psig}$ or greater. The tubing downstream of the mass-flow controllers to the external building vents does not contain valves or other significant flow restrictions. Therefore, the system through steam generators, superheaters, and other heat exchangers will operate at very low pressures (near atmospheric).

- The number of gas cylinders in the laboratory will be limited to the cylinders that are directly plumbed into an experiment plus an equal number of backup cylinders. Further, the maximum quantity of hydrogen gas in BCTC Bay 9 (cylinders and experiments) will be limited to 2,000 standard cubic feet.

- Leak tests are conducted upon installation of the system and upon start-up.

\section{Process heater hazards}

Much of the ILS operates at significantly elevated temperatures presenting potential hazards to personnel and equipment.

- Process heaters (steam generators, superheaters, air heater, and electrolysis hot zone) are inhouse designs controlled by the ILS DACS. There is the possibility that heaters could overheat 


if the computer-based control failed (power surge for example). This does not represent a
safety hazard but heaters could fail. Heaters are designed to handle the maximum temperatures
that could be produced under steady state, full power operation. The heaters are heavily
insulated and as described previously, the tubing system has no significant flow restrictions
through the heaters so over-pressurization is not possible. Also, the heater power supplies
allow users to set maximum voltage or current levels.
- Whenever any ILS heaters are in operation, "Caution Hot" signs will be posted and access to
exposed high-temperature surfaces will be restricted.
Electrical hazards
The ILS includes 480 -volt and 208-volt 3-phase input power and 208 -volt and 120-volt single-
phase power. The transformer and distribution panels are mounted on the ILS skid.
- The ILS transformer and distribution system were assembled by qualified electricians.
- A single 200 -amp 480 -volt 3 -phase tube-and-sleeve plug allows all power to the ILS to be
disconnected at a single point. This allows simple lockout-tagout procedures. Operation of
switches and/or circuit breakers above 240 -volt phase-to-phase will be performed only by
personnel with appropriate training, using appropriate PPE.
Unattended experiments
The ILS has been designed to be passively safe for unattended operation. The design incorporates
a UPS system for the data acquisition/system controller to operate through short-term power outages.
In the case of a long-term power failure such that the system-controller computer fails, the heaters
simply cool down and the gas flow stops, so no hazard exists even if the power subsequently comes
back on. The hazardous gas alarm system will automatically isolate hazardous gas flow and bring the
ILS to a safe state in the event of an evacuation alarm during periods of unattended operation. The use
of form 420.10 is not required.

Table 2.03. Waste generation.

\begin{tabular}{|l|l|l|l|l|}
\hline $\begin{array}{l}\text { Type of } \\
\text { Waste }\end{array}$ & $\begin{array}{l}\text { Generation } \\
\text { Location }\end{array}$ & $\begin{array}{l}\text { Anticipated } \\
\text { Volume }\end{array}$ & $\begin{array}{l}\text { Container } \\
\text { Type }\end{array}$ & Disposal Method \\
\hline $\begin{array}{l}\text { Paper, packing, } \\
\text { etc. material, } \\
\text { etc.) }\end{array}$ & BCTC Bay 9 & $8 \mathrm{ft}^{3} / \mathrm{yr}$ & Trash receptacles & Routine trash collection \\
\hline Metal shavings & BCTC Bay 9 & $<0.1 \mathrm{ft}^{3} / \mathrm{yr}$ & Trash receptacles & Routine trash collection \\
\hline
\end{tabular}

\begin{tabular}{|c|}
\hline $\begin{array}{l}\text { List any special needs/requirements for storage and handling wastes. } \\
\text { None. }\end{array}$ \\
\hline $\begin{array}{l}\text { If a spill occurs, how will it be cleaned up? } \\
\text { Notify WGS and Facility Project Manager (FPM) }\end{array}$ \\
\hline $\begin{array}{l}\text { Describe anything else that may be relevant for waste disposal purposes. } \\
\text { NA }\end{array}$ \\
\hline
\end{tabular}


Training Required

\begin{tabular}{|c|c|c|c|}
\hline \multicolumn{4}{|c|}{ Training of Project Personnel } \\
\hline Activity & Training Required & Activity & Training Required \\
\hline $\begin{array}{l}\text { General laboratory } \\
\text { activities }\end{array}$ & $\begin{array}{lr}\text { TRN670 } & \text { R\&D } \\
\text { Laboratory } & \text { Awareness } \\
\text { Training or equilivant } \\
\text { TRN722 Laboratory } \\
\text { Protective Equipment } \\
\text { 00INL838 } & \text { Industrial } \\
\text { Ergonomics } & \end{array}$ & $\begin{array}{l}\text { Pressurized } \\
\text { assembly }\end{array}$ & $\begin{array}{lr}\text { TRNV250 } & \text { Pressurized } \\
\text { System } & \text { Assembler } \\
\text { Training } & \end{array}$ \\
\hline $\begin{array}{l}\text { Safe handling of } \mathrm{H}_{2} \\
\text { gas }\end{array}$ & $\begin{array}{lr}\begin{array}{l}\text { SMJS992B } \\
\text { and }\end{array} & \text { Flammable } \\
\text { Materials } & \\
\end{array}$ & Safe handling of $\mathrm{O}_{2}$ gas & $\begin{array}{l}\text { SMJS992J, } \\
\text { Oxidizers/Pyrophoric } \\
\text { Agents }\end{array}$ \\
\hline $\begin{array}{l}\begin{array}{l}\text { Handling } \\
\text { compressed }\end{array} \text { of } \\
\text { cylinders }\end{array}$ & $\begin{array}{l}\text { TRN1041 Compressed } \\
\text { Gas Safety Training } \\
\text { 00TRN838 }\end{array}$ & $\begin{array}{l}\text { General handling of } \\
\text { chemicals }\end{array}$ & $\begin{array}{l}\text { TRN13 Chemical } \\
\text { Hygiene Plan Training } \\
\text { SMJS992C Carcinogens } \\
\text { \& Reproductive Toxins } \\
\text { SMJS992E Irritants, } \\
\text { Corrosives \& Sensitizers } \\
\text { SMJS992F Hepatotoxins, } \\
\text { Nephrotoxins/Neurotoxins } \\
\text { SMJS992L Agents Which } \\
\text { Damage The Lungs }\end{array}$ \\
\hline $\begin{array}{l}\text { Installation, } \\
\text { operation, and } \\
\text { troubleshooting } \\
\text { instrumentation } \\
\text { and power } \\
\text { supplies. }\end{array}$ & $\begin{array}{l}\text { INL427 Research and } \\
\text { Electrical Worker } \\
\text { Electrical Safety }\end{array}$ & & \\
\hline
\end{tabular}

\section{PREREQUISITES}

Additional LIs Supporting this LI:

JSA \#76-06-BCTC Assembly of Experimental Systems and Maintenance of Test Equipment

\section{Co-located Research Activities for this LI:}

IHR\#1162-06-BCTC, High-Temperature Corrosion Loop For Fuel Cells

IHR\#1181-06-BCTC, High Temperature Electrolysis

IHR\#1089-05-MSN-M1, Thermal Science Research 


\section{FACILITY CONDITIONS}

The DrägerGuard Safety Gas Monitoring System installed in BCTC Bay 9 must be operational and calibrated.

\section{INSTRUCTIONS}

Specific Experiment Test Plan

Equipment manuals and instructions are maintained in the file cabinet under the printer.

No radiological or highly hazardous activities have been identified.

\section{POST-PERFORMANCE ACTIVITIES}

None.

\section{ABNORMAL OPERATIONS}

Operations will not proceed under abnormal conditions unless approved by the Laboratory Manager, as appropriate, and the work remains within the bounds of this Laboratory Instruction. If a gas hazard evacuation alarm sounds, the researchers will exit the laboratory immediately. The procedures in GDE252, BCTC Bay 9 Emergency Response Guide, will be followed in the event of hazardous gas alarm activation in the laboratory.

\section{RECORDS}

Laboratory Notebooks, computer disks and computer files, and archives

Pressure Vessel Inspection Certificate

Form 361.25 Group Read \& Sign Training Rosters

\begin{tabular}{|l|l|l|l|}
\hline $\begin{array}{l}\text { Records } \\
\text { Description }\end{array}$ & $\begin{array}{l}\text { Uniform File } \\
\text { Code }\end{array}$ & $\begin{array}{l}\text { Disposition } \\
\text { Authority }\end{array}$ & Retention Period \\
\hline $\begin{array}{l}\text { Project case } \\
\text { Files }\end{array}$ & 8406 & RD1-A-2 & $\begin{array}{l}\text { Level II: Cutoff after } \\
\text { project/program completion, } \\
\text { cancellation, or termination. } \\
\text { Destroy 25 year after } \\
\text { termination of } \\
\text { project/program. }\end{array}$ \\
\hline
\end{tabular}

\section{REFERENCES}

GDE-252, BCTC Bay 9 Emergency Response Guide 
APPENDIXES (such as forms 420.07, 420.11, 440.37, and 420.10 as applicable)

None 